\title{
Satellite Contributions to the Quantitative Characterization of Biomass Burning for Climate Modeling
}

\author{
Charles Ichoku, Ralph Kahn, Mian Chin \\ Corresponding Author: \\ Dr. Charles Ichoku \\ Climate \& Radiation Branch, Code 613.2 \\ NASA Goddard Space Flight Center \\ Greenbelt, MD 20771, USA \\ Phone : +1-301-614-6212 \\ Fax : +1-301-614-6307 or +1-301-614-6420 \\ Email : Charles.Ichoku@nasa.gov
}

Lab. for Atmospheres, NASA Goddard Space Flight Center, Greenbelt, Maryland, USA

\begin{abstract}
Characterization of biomass burning from space has been the subject of an extensive body of literature published over the last few decades. Given the importance of this topic, we review how satellite observations contribute toward improving the representation of biomass burning quantitatively in climate and air-quality modeling and assessment. Satellite observations related to biomass burning may be classified into five broad categories: (i) active fire location and energy release, (ii) burned areas and burn severity, (iii) smoke plume physical disposition, (iv) aerosol distribution and particle properties, and (v) trace gas concentrations. Each of these categories involves multiple parameters used in characterizing specific aspects of the biomass-burning phenomenon. Some of the parameters are merely qualitative, whereas others are quantitative, although all are essential for improving the scientific understanding of the overall distribution (both spatial and temporal) and impacts of biomass burning. Some of the qualitative satellite datasets, such as fire locations, aerosol index, and gas estimates have fairly long-term records. They date back as far as the 1970s, following the launches of the DMSP, Landsat, NOAA, and Nimbus series of earth observation satellites. Although there were additional satellite launches in the 1980s and 1990s, space-based retrieval of quantitative biomass burning data products began in earnest following the launch of Terra in December 1999. Starting in 2000, fire radiative power, aerosol optical thickness and particle properties over land, smoke plume injection height and profile, and essential trace gas concentrations at improved resolutions became available. The 2000s also saw a large list of other new satellite launches, including Aqua, Aura, Envisat, Parasol, and CALIPSO, carrying a host of sophisticated instruments providing high quality measurements of parameters related to biomass burning and other phenomena. These improved data products have enabled significant progress in the study of biomass burning from space. However, appreciable uncertainty remains in many of the measurements that still needs to be addressed. Nevertheless, climate and other atmospheric models are
\end{abstract}


making significant adjustments to take advantage of quantitative satellite measurements in studying biomass burning activity, emissions, and impacts. New research directions should include not only improvements in satellite retrievals and modeling accuracies, but also increased synergy between them, such that satellite measurements can be directly input into models without requiring elaborate interpretation.

\section{Introduction}

Biomass burning is a widespread phenomenon affecting most vegetated parts of the world seasonally, either in the form of wildfires ignited by accident or by natural causes such as lightning, or prescribed fires used for agricultural, ecological control or other similar purposes (e.g. Andreae, 1991; Carmona-Moreno et al., 2005; e.g. Morton et al., 2008). Collectively, such large fires are among the fastest agents of terrestrial ecosystem change. Whereas prescribed fires are mainly intended for beneficial purposes, wildfires can have both direct and indirect adverse effects on human life and property, the environment (degradation, soil destabilization, and desertification), and water resources (soil moisture depletion and water pollution). They can also alter air circulation (convection and entrainment of smoke and subsequently soil particles), cloud formation and dissipation, and can effect Earth surface albedo changes. All of these have the potential to exert significant climate impacts that can trigger additional adverse responses and feedbacks (e.g. Cochrane, 2003; Shakesby and Doerr, 2006; Randerson et al., 2006; Bowman et al., 2009). Smoke emitted by fires is composed of aerosol particulate matter $(\mathrm{PM})$ and numerous trace gases, including carbon monoxide $(\mathrm{CO})$, carbon dioxide $\left(\mathrm{CO}_{2}\right)$, methane $\left(\mathrm{CH}_{4}\right)$, non-methane hydrocarbons, halogenated compounds, nitrogen oxides (NOx), and volatile organic compounds (VOCs), most of which are pollutants and contribute to the formation of new pollutants, such as tropospheric ozone $\left(\mathrm{O}_{3}\right)$ and secondary aerosols. These PM and trace gases can have significant impacts, not only on air quality and health, but some (e.g. $\mathrm{PM}$ and the greenhouse gases, $\mathrm{CO}_{2}$ and $\mathrm{CH}_{4}$ ) also affect climate, with potential feedback on air quality. For instance, smoke PM can influence precipitation processes resulting in delayed, suppressed, or invigorated rainfall (e.g. Rosenfeld et al., 1999; Andreae et al., 2004; Koren et al., 2004), change cloud albedo, and scatter and absorb solar radiation, affecting atmospheric warming or cooling, and contributing to climate change. Conversely, expected climatic-changes, such as more severe drought conditions in some regions, are likely to result in more frequent and possibly more severe wildfire events. These complex and multi-faceted impacts of biomass burning can be better characterized and understood only through accurate, quantitative assessment of the spatial and temporal patterns in fuel consumption, heat budgets, and emissions (e.g. Radke et al. 2000, Clements et al. 2007, Kremens et al. 2010). In particular, accurate estimation of smoke emission source strength from active fires is essential for modeling the smoke particulate and gaseous species fluxes, transport, atmospheric interactions, and impacts on air quality and climate.

For several decades, researchers have made efforts to estimate burned biomass and smoke emissions from ground-based and in situ measurements, but the spatial and temporal coverage is severely limited (e.g. Crutzen and Andreae, 1990; Andreae and Merlet, 2001; Reid et al., 2005a,b). The rapid growth of satellite measurement capability 
within the last couple of decades has provided the potential to overcome these space and time limitations by covering the entire globe frequently, over long periods of time. Henceforth, satellite data represent the primary source of information for mapping biomass-burning activity and evaluating smoke emissions at regional-to-global scales (e.g. Schultz et al., 2002; Freitas et al., 2005; Davies et al., 2009; Ichoku et al., 2008a; Kahn et al., 2008; Reid et al., 2009; Val Martin et al., 2010; van der Werf et al., 2010). However, satellite remote-sensing methods are faced with new challenges as they attempt to use instantaneous observational snapshots to address continuous and highly variable processes such as fires and their emissions. The result is that, although satellite can cover more ground, uncertainties in quantifying emissions still remain, and can in some respects be even greater, compared to the ground-based methods.

The aim of this review is to assess the contributions satellite remote sensing make to the quantitative characterization of biomass burning for air quality and climate modeling applications. As biomass burning is a vastly interdisciplinary subject whose many aspects have been explored for decades by scholars from different perspectives, including by laboratory and field experimentation, modeling, ground-based, airborne, and satellite approaches, this paper cannot possibly provide an exhaustive review of the subject matter. Rather, we focus the discussion on the contributions from satellite, by way of cataloguing the significant satellite measurements that are directly relevant to the study of biomass burning and its impacts. We examine the current uncertainty levels of some of these satellite products, discuss their current or potential uses, and address some of the limitations and gaps that still exist in these satellite products. We also summarize their existing or potential synergy with modeling that does or could help improve scientific understanding of the biomass burning phenomenon and its impacts, quantitatively, at regional to global scales.

Scientific understanding of biomass burning and its impacts requires a fundamental knowledge of three important aspects: (1) the types and spatio-temporal distributions of biomass burning events, (2) the different physical components of a biomass burning process, and (3) the products of biomass burning, their properties, and their trajectories. These three aspects are discussed in more detail in the subsections that follow, within this introduction. Section 2 describes the satellite observational constraints in measuring basic parameters related to biomass burning, including brief highlights of their current uncertainty levels and some of their relevant applications. Section 3 examines the three aspects of modeling that are most frequently used in biomass burning studies, namely: plume-rise, transport, and inverse modeling. Section 4 addresses the need for synergy between satellite measurements and modeling, through the unification of their hitherto disparate parameter systems, in order to make them more compatible and amenable to better comparison and possible integration. Section 5 completes the paper, with a brief conclusion and recommendations for future research aimed at enhancing the use of quantitative satellite data for improving biomass-burning parameterizations in the models used for climate and air-quality research and applications.

\subsection{Types and Distribution of biomass burning (emphasis on the global extent)}

Biomass burning encompasses the combustion of all types of organic material, particularly plants (living or dead), and includes the use of wood for domestic cooking or charcoal making, as well as open biomass burning in nature (e.g. Lacaux et al., 1994). 
Since this review deals with the satellite contributions to climate modeling, it focuses on open biomass burning, which is observable from space, unlike domestic cooking and charcoal making that are typically performed at relatively smaller scales and under cover, and therefore not amenable to satellite observation. Open biomass burning varies widely in terms of ignition processes, size, intensity, spread rate, duration, seasonality, frequency of recurrence, and emission characteristics; depending on ecosystem type, location, prevailing weather, and fuel characteristics (e.g. physical composition and arrangement, density, degree of intrinsic dryness, and dampness due to precipitation or ambient humidity).

The research community typically classifies biomass-burning regimes on the basis of broad ecosystem categories (Fig. 1) that include boreal forest, peat land, tropical forest, savanna/grassland, and agricultural fires (e.g. Andreae and Merlet, 2001; van der Werf, 2010). However, ecosystem types are much more varied, having several levels of subtype nesting, and so are fire regimes, as the basic drivers of fire behavior and emission source strength are the fuel characteristics. Indeed, there can be significant differences between fire regimes of the same ecosystem type in different geographical locations. For instance, analysis of fire radiative energy (FRE) release rate or power (FRP) from the Moderate-resolution Imaging Spectro-radiometer (MODIS) instrument, which flies aboard the Terra and Aqua satellites, has shown that "boreal forest fires burn less intensely in Russia than in North America" (Wooster and Zhang, 2004). This suggests that Russian boreal fires typically burn less vigorously, consuming fuel and emitting smoke at a slower rate than their North American counterparts, fire-for-fire. Similar differences in mean FRP per MODIS fire pixel were also found between the tropical forests in Africa, Brazil, and Southeast Asia, as well as for other ecosystem types in different regions (Ichoku et al., 2008a). These differences are probably due to a combination of the factors identified above.

\subsection{Physical components of biomass burning}

The physical components of biomass burning include: the biomass fuel, the fire (represented by flame and other pyrolysis processes), the energy released (propagated by conduction, convection, radiation), and the smoke emissions (including aerosols and trace gases). Full characterization of biomass burning activity entails detailed, quantitative analysis of these individual components and their mutual interrelationships.

As indicated in the previous subsection, fuel characteristics and environmental conditions drive fire behavior and emissions. Therefore, to predict these biomass burning processes accurately, it is necessary to understand fuel distribution and properties, such as whether they consist mainly of live or dead vegetation, leaves or stems, individually large or thin elements, and whether they are standing or lying down, sparsely or densely loaded, dry or humid. The presence or absence of flame determines the nature of the underlying pyrolysis process, which affects the rates of combustion, consumption of biomass, energy release, and emissions. The nature and rate of energy release, the first physical output from fires, reflects the combustion process and its potential direct impact, as well as the emission source characteristics. Emissions of particles and trace gases constitute the second main product of fires. Whereas the direct effects of the energy produced are limited to the immediate locality and duration of the fire, the direct effects of the emissions can be quite extensive in both space and time, depending on smoke 
particle and gaseous composition, transport and atmospheric residence time (e.g. Damoah et al., 2004).

\subsection{Context - The importance of biomass burning for air quality and climate}

A third fundamental aspect of biomass burning is the generation and trajectory of the energy and smoke produced. Biomass burning processes release tremendous amounts of heat energy, which is propagated in the form of conduction, convection, or radiation. These different components exert influences that can affect air quality and climate indirectly. Whereas the heat of combustion removes the vegetative cover and produces particles, water vapor, and other gases, the part of the heat conducted to the ground can enhance surface evaporation, thereby drying out the soil. The drying and burning change the surface albedo, which has climate implications. The altered surface also lends itself more easily to wind generation of airborne ash and dust, which affects both air quality and climate. The convective energy, in the form of latent and sensible heat, provides the transport mechanism for injecting both the trace gases (including water vapor) and aerosols into different levels of the atmosphere, where they can affect both the air quality and climate to varying degrees, depending on their composition and atmospheric residency times. The radiative energy from biomass burning contributes to the long-wave surface radiation that affects the terrestrial heat budget and eventually climate, although the significance of this contribution is yet to be investigated.

Smoke from biomass burning is composed of aerosol particulate matter (PM) and a wide variety of trace gases (e.g. Andreae and Merlet, 2001). Different smoke constituents have different degrees of relevance to air quality and/or climate, depending on their spatial and temporal distribution and their physical, chemical, and/or optical characteristics. To evaluate smoke climate impacts, the general aspects of both aerosol and trace gases considered are their atmospheric loading, vertical distribution, and lifetime. In other words, for a given smoke constituent and location, the denser it is within the volume it occupies and the longer it lasts in that volume the more its potential climate impacts. Aerosols typically have a lifetime of about one week in the atmosphere depending on how high they are injected into the atmosphere, whereas trace gases have a wide range of lifetimes going from a few hours to hundreds of years depending on the species. For instance, nitric oxide (NO) and nitrogen dioxide $\left(\mathrm{NO}_{2}\right)$ last a few hours to a day, carbon monoxide $(\mathrm{CO})$ a few weeks, carbon dioxide $\left(\mathrm{CO}_{2}\right) \sim 100$ years, and nitrous oxide $\left(\mathrm{N}_{2} \mathrm{O}\right)$ even longer. The unique characteristics of smoke aerosol PM considered most critical for climate are the physical composition and associated optical (scattering and absorption) properties. Smoke PM includes mainly organic carbon (OC) and black carbon (BC), with numerous other PM species emitted in relatively smaller amounts. Overall, it is estimated that biomass burning contributes about $34 \%-38 \%$ of global total carbonaceous aerosol emissions, while the rest is from fossil fuel burning (e.g. Forster et al., 2007). Although OC concentrations in biomass burning smoke emissions are typically 5 to 10 times larger than $\mathrm{BC}$ concentrations, $\mathrm{BC}$ is by far more absorbing than $\mathrm{OC}$. Indeed, it has been reported that global mean radiative forcing by $\mathrm{BC}$ is up to $55 \%$ that of $\mathrm{CO}_{2}$, and larger than that of any other greenhouse gases (Ramanathan and Carmichael, 2008). That and other studies also suggest that BC deposition can darken snow and ice surfaces, contributing to melting, in particular of mountain glaciers and Arctic sea ice (e.g. Hansen and Nazarenko, 2004), and that $40 \%$ of global BC loading can be attributed to open biomass burning alone. The unique relevance of trace gases to climate depends 
on their greenhouse gas properties, which is related to their optical properties. For example, $\mathrm{CO}$ has practically no greenhouse effect, and is therefore much less important for climate than $\mathrm{CO}_{2}, \mathrm{CH}_{4}$, and $\mathrm{N}_{2} \mathrm{O}$ whose greenhouse effects are large. It is estimated that land-use changes due to deforestation and associated biomass burning accounts for about $25 \%$ of the total global $\mathrm{CO}_{2}$ increases since pre-industrial times (e.g. Forster et al., 2007).

With regard to air quality, the relevance of all smoke constituents is associated with their abundance and spatio-temporal distribution close to human populations. In other words for a given smoke constituent, the more concentrated it is and the closer it is to the ground in densely populated areas and the longer it remains in such locations, the greater the potential for human exposure and adverse effects on air quality. Specifically, under the US Clean Air Act (http://www.epa.gov/air/criteria.html) that was last amended in 1990, the US Environmental Protection Agency (EPA, 2005) was required to set National Ambient Air Quality Standards (NAAQS, 40 CFR part 50) for six pollutants considered harmful to public health and the environment, identified as 'criteria pollutants' (e.g. Koren, 1995), namely: Particulate Matter (PM), Carbon Monoxide (CO), Nitrogen Oxides ( $\mathrm{NO}$ and $\mathrm{NO}_{2}$, commonly referred as $\left.\mathrm{NO}_{\mathrm{x}}\right)$, Sulfur Dioxide $\left(\mathrm{SO}_{2}\right)$, Ozone $\left(\mathrm{O}_{3}\right)$, and Lead $(\mathrm{Pb})$. Essentially, emissions from biomass fires contribute significantly to five of these six pollutants, as the first four (i.e. $\mathrm{PM}, \mathrm{CO}, \mathrm{NOx}$, and $\mathrm{SO}_{2}$ ) are directly emitted by the fires, and $\mathrm{O}_{3}$ is produced through a sunlight-induced chemical reaction between NOx and volatile organic compounds (VOCs), that themselves are also emitted by fires.

Consideration of PM effects on air quality is based on its physical characteristics, particularly size. Depending on fire type, smoke PM, like most atmospheric aerosol particles, falls within the size range of PM10 (particles having aerodynamic diameter $<10$ $\mu \mathrm{m}$ ), of which the dominant proportion falls within the PM2.5 (particles with aerodynamic diameter $<2.5 \mu \mathrm{m}$ ). The fine (PM2.5) aerosol category is of greater concern for air quality than the coarse (PM10 - PM2.5) fraction because the smaller particles are able to penetrate human lungs, where they can contribute to cardiovascular and respiratory diseases. Although PM2.5 constitutes a significant proportion of most aerosol types, including the naturally occurring categories such as wind-blown dust and oceanspray generated sea salt aerosols, as well as anthropogenic pollution from urban/industrial/transportation and other human activities, the smoke contribution is particularly important because it is frequently emitted from vegetated land surfaces where people live, as opposed to uninhabited desert or ocean regions; this is especially true of agricultural fires. Furthermore, because of the unpredictable character of natural fire occurrence, smoke is more likely to diminish air quality unexpectedly, unlike emissions from regular human activities, which generally have a predictable rhythm.

The unique relevance of individual fire-emitted trace gas species to air quality does not necessarily depend on their relative abundance. For instance, although $\mathrm{CO}_{2}$ is emitted in much higher proportions than CO (about 15:1 for many types of fires, e.g. Andreae and Merlet, 2001), the latter is probably the more critical for air quality because, even though $\mathrm{CO}$ from fire is generally lower than the typical pollution standard, it is important as a marker for pollution and is also an ozone precursor (e.g. Pfister et al., 2008). Also, NOx and $\mathrm{SO}_{2}$ are emitted from fires in even smaller quantities, typically much lower than harmful pollution levels, but are important precursors for ozone and sulfates, respectively. 
Essential inputs required by models for accurate air-quality monitoring and forecasting can be derived from satellite measurements, which can complement/supplement the surface-based measurements where these exist and represent the only source of air-quality data where they do not (e.g. Al-Saadi et al., 2005; Grell et al., 2005; Byun and Schere, 2006; Hoff and Christopher, 2009; van Donkelaar et al., 2010).

\section{Satellite Observational Constraints}

Some of the variables associated with biomass burning have been observed from space in one form or another since the beginning of the satellite earth observation era in the 1970s. This period saw the launches of the first Landsat in 1972, the first Advanced Very High Resolution Radiometer (AVHRR) aboard the TIROS-N satellite in 1978, and the first Total Ozone Mapping Spectrometer (TOMS) aboard the Nimbus 7 satellite in 1978. The Landsat satellite series, as well as the AVHRR and TOMS sensor series and many other earth observation satellite sensors launched in subsequent years and into the new Millennium, have enabled great progress in the observation of different climate relevant parameters, including those related to biomass burning, both on the earth's surface and in the atmosphere. Table 1 presents a list of some key variables, and Table 2 shows those observed by different satellite sensors, listed in order of satellite launch date. In cases where a series of similar satellites is involved, only the launch date of the first one is shown. The satellite and sensor acronyms and their full names, preceded by those of the Agencies operating them, are listed in Table 3. The acquired observations have varying degrees of quantitative importance, and fall under different product categories that will be discussed in the following subsections. The satellite-derived variables are listed individually along with their observing sensor/satellite identities, data characteristics, and relevant references for fires and smoke, respectively, in Tables 4a and $4 b$.

\subsection{Active Fire Detection}

Although the Defense Meteorological Satellite Program (DMSP) spaceborne systems became operational in the 1960s, and their satellite imagery declassified in December 1972, their utility for active fire detection was not exploited by the scientific community until much later (e.g. Cahoon et al., 1992a). The breakthrough in fire detection from space came after the 1978 launch of the first AVHRR, when algorithms were developed to measure surface radiant temperature fields at sub-pixel resolutions (e.g. Dozier, 1981; Matson and Dozier, 1981). With successive launches of the AVHRR series of sensors in the later part of the 1980s, that initial effort evolved into targeted fire detection from satellite (e.g. Malingreau et al., 1985; Muirhead and Cracknell, 1984; Flannigan and Vonder Haar, 1986; Matson and Holben, 1987). The 1990s saw increased activity in satellite fire remote sensing, not only from AVHRR (at 1-km nominal spatial resolution at nadir), but also from other similar polar orbiting satellite sensors such as the ATSR (Arino and Melinotte, 1995), as well as geostationary satellite sensors such as the GOES VAS (and later the IMG) series, whose observations are acquired at 4-km nominal spatial resolution at the sub-satellite point (e.g. Kaufman et al., 1990; Malingreau, 1990; Lee and Tag, 1990; Setzer and Pereira 1991; Prins and Menzel, 1992; Justice et al., 1993; 
Langaas, 1993; Kennedy et al., 1994; Eva and Flasse, 1996; Flasse and Ceccato, 1996; Justice et al., 1996; Scholes et al. 1996; Randriambelo et al., 1998; Giglio et al., 1999). With the launch of Terra in December 1999 came higher-spatial-resolution fire detection capability with the Advanced Spaceborne Thermal Emission and Reflection Radiometer (ASTER at $30 \mathrm{~m}$ ), as well as much improved radiometric stability, combined with 1-km spatial resolution (similar to that of AVHRR) from MODIS (e.g. Kaufman et al., 1998a, 2003; Giglio et al., 2000, 2003a,b, 2008; Giglio and Kendall, 2001; Justice et al., 2002; Giglio, 2007). This improvement in satellite fire detection capability was further reinforced with the launch of a second MODIS sensor in 2002 aboard the Aqua satellite. Since the nominal equator crossing times of Terra are 10:30 am and 10:30 pm, whereas those of Aqua are 1:30 am and 1:30 pm, the twin MODIS sensors can observe fires globally everywhere on average four times daily; once in the daytime and once at nighttime from each sensor. Several other sensors providing fire detection from polar or geostationary orbits were also launched during the late 1990s and into the 2000s, up to the launch of the Visible Infrared Imager Radiometer Suite (VIIRS) aboard the NPP polar-orbiting satellite in October 2011. Some of these sensors are still operational; details are provided in Tables 2 to 4 .

Accurate identification and detection of active fires from satellite is of primary importance in the assessment of satellite contributions to the quantitative characterization of biomass burning, because it is important to determine: (i) what fraction of actively burning fires at satellite overpass time are actually detected, and (ii) what fraction of satellite detections are actual fires, as opposed to artifacts. Several studies conducted mostly during the last decade have been dedicated to addressing these complementary questions (e.g. Li et al., 2001, 2003; Ichoku et al., 2003a; Stolle et al., 2004; Morisette et al., 2005a,b; Schroeder et al., 2005, 2008a,b,c; Csiszar et al., 2006; Mota et al., 2006; Csiszar and Schroeder 2008; Calle et al., 2009). The methodology employed in those studies typically involves comparing the satellite active fire detections at a given spatial resolution against those acquired from satellite or airborne sensors at higher resolution, or matching reported detections against burn scars or burned areas mapped using groundbased, airborne, or space-based methods.

Typically, such studies quantify the non-detection of existing fires in terms of 'omission' errors, and the reporting of a fire where there is none as 'commission' errors. Omission errors are attributable to several factors, including limitations due to physical fire size relative to the satellite sensor footprint and/or the fire temperature differential with that of the background, as well as fire obscuration by clouds, thick smoke, topographic relief or other tall features, and even large vegetation canopy camouflaging of understory fires. Commission errors can occur from signal enhancement in the fire channels due to sun glint, hot bare surfaces, certain types of clouds, and other discrete and unique hot features.

As commission errors originate from special circumstances, occur infrequently, and have a much lower impact on fire characterization than omission errors, we focus our accuracy discussion to omission errors. Even the discussion of omission errors alone is quite complex, as apart from the question of detecting fires during the time of satellite overpass, there are also larger questions regarding the fire sampling times and frequency relative to overall fire diurnal and annual occurrence patterns in different regions (e.g. Giglio, 2007). Some of the fire-detection uncertainty analyses studies cited above, 
particularly those based on matching active fire pixels against cumulative burned areas, encompass the omissions of fires that are not active during the satellite overpass as well, and therefore provide an unrealistic measure of satellite performance. The fire-detection uncertainty analysis in this paper focuses on studies that compare satellite products with near-coincident higher-resolution observations, either from satellite or airborne measurements. Incidentally, it is difficult to adopt a single absolute value of omission error threshold for different sensors having substantially different footprint sizes, as the major limiting factor in fire detection is the ratio of fire size to footprint size. For instance, in a number of recent studies, ASTER and/or Landsat ETM+ fire detections at 30-m nominal spatial resolution were used to validate MODIS fire detections at $1-\mathrm{km}$ nominal spatial resolution, which contains approximately $110030-\mathrm{m}$ pixels. The probabilities of omission were found to be in the ranges of $80 \%-90 \%, 20 \%-40 \%$, or $5 \%$ $10 \%$ when the minimum number of 30 -m pixels required within a MODIS pixel for the latter to be validated as a true fire pixel were set as 1,50 , or 100 , respectively (e.g. Morisette et al., 2005a,b; Schroeder et al., 2008b,c). Similar validation of GOES geostationary fire detection at 4-km nominal spatial resolution showed that, although its nominal pixel area is 16 times that of MODIS (at $1-\mathrm{km}$ resolution), these omission probabilities are produced with thresholds set to four times the respective minimum number of 30-m pixels used for MODIS (Schroeder et al., 2008b). Therefore, depending on their footprint size, satellite observations at $1-\mathrm{km}$ resolution or larger tend to miss quite a substantial number $(>80 \%)$ of relatively small-size fires (a few tens of meters in size), unless there is a high concentration $(>50)$ of such small fires within the satellite footprint, whereupon they detect $>50 \%$ of the fires. Detection capability increases with fire size relative to satellite footprint, but not necessarily in a linear fashion.

There are also other issues related to satellite fire detection. Cloud obscuration has long been recognized as a persistent problem unrelated to the fire detection algorithm adopted (e.g. Kaufman et al., 1998a). This problem is either ignored when working with satellite fire detections or compensated for on the basis of certain assumptions about fire and cloud distributions. Typically, the observed fires are weighted by cloud fraction in such a way as to account for potentially obscured ones, under the assumption that clouds have no effect on fire occurrence, and that in a given region, fire distribution in cloudfree areas is similar to that of cloud-covered areas (e.g. Roberts et al., 2005). The accuracy of this assumption is uncertain. However, Schroeder et al. (2008a) investigated the cloud obscuration problem in detail for the Brazilian Amazon region using a pixelbased probabilistic approach, together with information about 'previous fire occurrence, precipitation, and land use', and found that cloud adjustment reproduced the number of potential fires missed within ' $1.5 \%$ and $5 \%$ of the true fire counts on annual and monthly bases, respectively' (Schroeder et al., 2008a). Another major issue in fire omission relates to the frequency of satellite fire sampling. This is more of an issue for polar orbiting satellites that can observe fires no more than twice per day, than it is for geostationary satellites, whose sensors can observe fires at least twice an hour in the regions they cover. Current efforts are geared toward an amalgamation of the polar-orbiting and geostationary observations to derive the maximum benefit of spatio-temporal coverage and detection accuracy (e.g. Freeborn et al., 2009; Reid et al., 2009).

Although active fire detection enables the identification of their geographic location, which is fundamental and important for mapping the fire distribution, it takes much more 
than fire location to improve our understanding of the overall fire activity and impacts (e.g. Schroeder et al., 2009). To accomplish such studies with any degree of rigor, it is also important to establish the burn characteristics that can lead to quantitative estimates of burned biomass and smoke emissions.

\subsection{Fuel Type, Fuel Load, and Burned Area Mapping}

Fuel is the basic raw material for biomass burning, and knowledge of fuel characteristics and consumption by fires can provide insight into the carbon emission parameters relevant for climate studies. Fuels consumed during open biomass burning consist of organic materials, most of which are plants of various sizes and structures, and are often broadly differentiated based on the dominant vegetation types, such as grassland, brush, woodland, forest, agricultural residues, peat, and others (Fig. 1). However, for detailed characterization, fuel types are classified in terms of the sizes, shapes, physical disposition (i.e. whether they are above, on, or below ground), and state (i.e. live or dead) of the various plant elements: grass, leaves, foliage, twigs, stems, fine leaf litter, coarse woody debris, organic soil layer, peat, etc. (e.g. Burgan et al., 1998; van der Werf et al., 2006). Traditionally, fuel type and fuel load are characterized by groundbased sampling, sometimes beneath plant canopies, in order to document and quantify these elements as accurately as may be necessary to obtain good estimates of fuel carbon content before and after fires (e.g. Ottmar et al., 2007). Such detailed fuel characterization is currently not feasible from satellite, but ground-based and airborne (e.g. Saatchi et al., 2007) approaches can complement broad categorizations of landcover types from satellite to estimate fuel loads over large areas for fire behavior studies and emissions calculations.

Over the last several decades, substantial scientific efforts have been devoted to estimating biomass-burning carbon emissions, mostly by the use of models. Traditionally, the amount of fire-emitted carbonaceous aerosol or trace gas species of interest is derived as follows (e.g. Lavoue et al., 2000; Andreae and Merlet, 2001):

$$
M_{x}=E F_{x} * M_{\text {biomass }}
$$

where $M_{x}$ is the mass of the emitted species $x, E F_{x}$ is its emission factor, and $M_{\text {biomass }}$ is

the mass of the dry biomass burned, which can be estimated as follows (Seiler and Crutzen, 1980):

$$
M_{\text {biomass }}=A \times B \times \alpha \times \beta
$$

where $A$ is the burned area, $B$ is the biomass density, $\alpha$ is the fraction of aboveground biomass, and $\beta$ is the burn efficiency or combustion completeness. The definition and application of $\alpha$ presumes that biomass below ground does not burn, although more recent research has revealed that fires can burn deep into the ground under certain conditions, such as for peat in the Arctic/sub-Arctic regions (e.g. Nichol, 1994; Soja et al., 2004; Mack et al., 2011). Burned area $A$ can be directly measured from satellite to different degrees of accuracy and precision, depending on several factors, particularly the sensor spatial resolution, because the coarser the resolution the smaller the fraction of the actual subpixel burned area within individual pixels (e.g. Barbosa et al., 1999a; Roy et 
al., 2002). A number of satellite-derived global burned area products currently exist, including the Global Burnt Area product from SPOT/VEGETATION (Grégoire et al., 2003; Tansey et al., 2004, 2008), the GLOBSCAR product from the ATSR-2 sensor on the ERS-2 satellite (e.g. Simon et al., 2004), and MODIS Level 3 gridded Burned Area Product (MCD45A1) (e.g. Roy et al., 2008a). In addition, there have been various research burned area products derived from single or multiple sensor data for targeted applications (e.g. Fraser et al., 2000; Smith et al., 2002; Zhang et al., 2003; Li et al., 2004; Giglio et al. 2006; Zhang and Kondragunta, 2008; Soja et al., 2009).

Accuracy of burned area products is extremely important in determining the burned biomass. However, although the satellite remote-sensing approach provides the most practical way to produce sustained burned-area mapping, particularly for very large or extended regions, achievable accuracy is determined by several factors, including the sensor pixel size relative to the actual size of the burned area, as well as land-cover and soil-type differences (e.g. Miettinen et al., 2009). Inter-comparison between different burned area products revealed very large disagreements in different regions. For instance, Tansey et al. (2004) reported one example for the Brazilian forest in which, 'compared to the GLOBSCAR product that reported $4333 \mathrm{~km}^{2}$ of forest burned, the GBA-2000 product reported only $846 \mathrm{~km}^{2}, 80 \%$ less'; although this disagreement cannot be attributed to pixel size differences. However, more detailed validation of satellite-derived burned-area products have been conducted in various regions, usually based on burned areas derived from higher-resolution images, with varying results. Fraser et al. (2004) used Landsat TM-derived burned area maps at 30-m spatial resolution to validate those of AVHRR and SPOT/VGT for Canada and found that 'VGT burned areas were, on average, 72\% larger than crown fire burned areas mapped using Landsat TM'. On the other hand Zhang et al. (2003) performed similar studies in the Russian Federation and found VGT to underestimate burned areas by about $17.6 \%$ relative to Landsat ETM+. These contrasting results may be due to differences in algorithm assumptions in mapping burned areas both from the VGT and Landsat data, and represents a major concern for the user community, such as emissions modelers.

In contrast to burned area $A$, the other three variables in equation (2) are currently not directly measureable from satellite. Instead, they are typically estimated by modeling and other indirect approaches, often based on the use of fuel-load inventories from groundbased measurements and other compilations (e.g. Hao and Liu, 1994; Hoelzeman et al., 2004; Ito and Penner, 2004; Kasischke and Penner, 2004; Palacios-Orueta et al., 2004). For instance, Barbosa et al. (1999b) estimated biomass density $B$ by correlating literature values with accumulated normalized difference vegetation index (NDVI) as derived from AVHRR data. Luckman et al. (1998) employed a semi-empirical technique using spaceborne synthetic aperture radar (SAR) imagery, together with other data and model fitting, to estimate the aboveground biomass density (corresponding to $B \times \alpha$ in Eq. (2)). Also, there have been some efforts to use Multi-angle Imaging Spectro-Radiometer (MISR) observations to estimate aboveground woody biomass (e.g. Chopping et al., 2008). As regards burn efficiency $\beta$, De Santis et al. (2010) improved $\beta$ values obtained by traditional methods, using burn severity estimates from Landsat data, as reported in the literature by different authors (e.g. Van Wagtendonk et al., 2004; Epting et al., 2005; Miller et al., 2007; French et al., 2008; Verbyla et al., 2008; De Santis et al., 2010). 
Although the burned-area and related products represented in Eq. (2) are valuable for estimating total emissions, key satellite data needed to apply this approach can be obtained only several days to weeks after a fire is over. Therefore, they are utilized for developing emissions inventories, which are used for climate modeling, but do not meet the near-real-time application needs of air-quality management and forecasting. However, as demonstrated in a number of recent publications, near-real-time emissions can be derived from satellite measurements of FRP (e.g. Ichoku and Kaufman, 2005; Jordan et al., 2008) and perhaps also other quantitative measurements, such as sub-pixel instantaneous active fire area and temperature (e.g. Zhang et al., 2008; Reid et al., 2009).

\subsection{Fire Radiative Power and other Quantitative Measurements of Fire Energetics}

The high temperatures associated with actively burning fires result in a sharp increase in the middle infrared (MIR) emitted radiance compared to the background. This enables space-borne sensors with MIR channels in the atmospheric window near the 4- $\mu \mathrm{m}$ wavelength to detect fires occupying only a small fraction of their nominal pixel areas, but can also cause these channels to saturate. Thus, most heritage satellite sensors simply identified fire locations without providing any quantitative information, causing most satellite-based scientific analysis and modeling studies of biomass burning to rely on fire pixel counts or burned area estimates, neither of which has direct, quantitative information related to heat release, biomass consumption, or smoke emission. MODIS was the first satellite-borne sensor capable of measuring FRP, which is the fire radiative energy (FRE) release rate (e.g. Kaufman et al., 1998a; Justice et al., 2002; Giglio et al., 2003a, Ichoku et al., 2008, see also Fig. 2). Subsequently, FRP is being derived from a few other satellite sensors, including the Meteosat-SEVIRI and GOES Imager geostationary systems (e.g., Wooster et al., 2003; Roberts et al., 2005; Xu et al., 2010; Table 4a). Because of the discrete nature of remote sensing data acquisition, only instantaneous power (FRP) can be measured directly from satellite, and if measured over the same fire at a suitable temporal frequency, energy (FRE) can be derived by integrating successive FRP measurements over a given time period. Although satellite FRP has never been validated nor related directly to physical factors typically used to assess fire behavior quantitatively, such as fuel load and fuel-bed structure, actual subpixel fire area, flaming/smoldering phases, latent and sensible (convective) heat fluxes, or combustion completeness, it is increasingly being used to estimate burned biomass and smoke emissions, as well as for related scientific research (e.g. Wooster, 2002; Ichoku and Kaufman, 2005; Roberts et al., 2005; Wooster et al., 2005; Freeborn et al., 2008; Jordan et al., 2008; Pereira et al., 2009; Vermote et al., 2009). For instance, using satellite measurements of FRP and aerosols, coupled with meteorological wind fields, Ichoku and Kaufman (2005) demonstrated a direct linear relationship between FRP and smokeaerosol or particulate matter (PM) emission rates for various regions of the world. However, as will be discussed in section 3.1, there are a number of issues yet to be resolved in interpreting FRP, such as unknown fire emissivity, degree of atmospheric opacity at 4 microns, and the effects of partially filled pixels and observation scan angle.

Other quantitative measures of active fires, currently derivable from satellite measurements and applicable in near real-time, are the instantaneous sub-pixel fire area and temperature (e.g. Prins and Menzel, 1992; Giglio and Kendall, 2001), which 
incidentally can be used together to derive FRP (e.g. Wooster et al., 2003). Sub-pixel fire area and temperature are typically jointly derived, based on the difference in the response of a mid-infrared (MIR, typically around $4 \mu \mathrm{m}$ ) and a thermal infrared (TIR, typically around $11 \mu \mathrm{m}$ ) channel to emitted infrared spectral radiance from fires, by using the bispectral method developed by Dozier (1981). This method assumes that a fire pixel is composed of two thermal components ('fire' and non-fire 'background'), and by solving two simultaneous equations with two unknowns the sub-pixel fire area and temperature can be estimated. Although these measures provide more quantitative information on the sub-pixel fire activity than simple fire pixel counts, there are also uncertainties associated with them. First, when fires are undetected as described above, the inherent error of omission introduces uncertainty, and the ability to derive quantitative measures of the fires is inconsequential. Even, when the fires are detected, many of the fire sensing instruments' fire channels are easily saturated when the brightness temperature of the fire pixel exceeds the intensity tolerance of the detector measuring it. This saturation invariably results in significant uncertainty in the derived values of sub-pixel fire area, temperature, or FRP. In addition, vegetation fire scenes typically consist of multiple thermal components with a wide range of temperatures, from hot flaming to cooler smoldering components, making the assumption of a unique fire temperature unrealistic.

Indeed, Giglio and Kendall (2001) analyzed Dozier's (1981) method in detail and found it to have significant intrinsic uncertainty, which they summarized as follows: 'The results of a sensitivity analysis indicate that under realistic conditions the random errors in fire temperature and area retrieved using Dozier's method are $\pm 100 \mathrm{~K}$ and $\pm 50 \%$ at one standard deviation, respectively, for fires occupying a pixel fraction greater than 0.005 (this corresponds to a $5000-\mathrm{m}^{2}$ fire within a $1-\mathrm{km}$ pixel)'. They also noted that 'for smaller active fires, larger random and systematic errors are likely to occur' (Giglio and Kendall, 2001, p. 34). One of the most likely sources of uncertainty in the bi-spectral method could be the inter-channel pixel mis-registration or differences in point spread function (PSF) between the two spectral channels used (e.g. Wooster et al., 2005). Zhukov et al. (2006) suggested processing pixel clusters, rather than individual pixels, as a way to mitigate these sources of uncertainty.

FRP uncertainties have also been specifically investigated by several authors (e.g. Wooster et al., 2003, 2005; Roberts and Wooster et al., 2005; Schroeder et al., 2010; Xu et al., 2010). Analysis of fires observed over the Brazilian Amazon show the lower detection limit to be 11 and 9 MW for MODIS on Terra (morning) and Aqua (afternoon) satellites, respectively, whereas the equivalent detection limits for retrievals by the WFABBA algorithm are 27 and 19 MW for GOES observations coincident with Terra and Aqua overpass times, respectively (Schroeder et al., 2010). Similar analysis of GOES data across the Americas (North, Central, and South) reveals that the minimum detection limit for both GOES East and West is $\sim 30 \mathrm{MW}$ (Xu et al., 2010). The foregoing two studies conducted about the same time are in general agreement. Overall, because of the omission of smaller fires, it has been estimated that Geostationary - Meteosat-SEVIRI and GOES - sensors (at 3-4 km nominal spatial resolution) underestimate MODIS (at 1 $\mathrm{km}$ nominal spatial resolution) in regional total FRP by $40-50 \%$ (e.g. Roberts and Wooster, 2008; Xu et al., 2010). In turn, MODIS was found to underestimate FRP by up to $46 \%$ compared to the Bi-spectral InfraRed Detection (BIRD) small satellite Hot Spot 
Recognition System (HSRS) sensor (at 0.37-km nominal spatial resolution), based on a relatively few cases examined (Wooster et al., 2003).

Therefore, although space-based quantitative measures of active fires, such as FRP, allow the categorization of the relative sizes/intensities of the fires (e.g. Ichoku et al., 2008a), which have the potential to improve the accuracy of fire activity and emissions characterization, these quantitative measures still appear to suffer from significant uncertainty, almost certainly in the direction of underestimation. This is due to the massive omission (both in space and time) of fires that are: (i) too small relative to the satellite-sensor footprint, (ii) active only between satellite overpasses or measurements, or (iii) obstructed from satellite sensor view by clouds, thick smoke, large tree canopies, mountains, or other large features. In essence, the overriding uncertainty issue with fire observation from space is underestimation.

\subsection{Smoke Plume height mapping and Vertical Profiling}

An important factor in determining the impact of smoke on air-quality and climate is its vertical distribution. Smoke affects air quality mainly when it is near the surface, where populations can be directly exposed, whereas elevated smoke is likely to spread farther from its source and remain in the atmosphere longer, increasing its environmental impact. Smoke plume heights are successfully being characterized from space using two main techniques: stereo analysis of overlapping imagery from passive remote sensing, and analysis of Lidar return signals from active remote sensors.

Passive remote sensing stereo mapping of plume height is being conducted mainly from Multi-angle Imaging Spectro-Radiometer (MISR) observations. The multi-angle measurement capability of MISR allows the determination of heights of various types of targets (e.g. clouds and aerosols) that have features visible in multiple images acquired from different view angles, and to include a wind correction for proper cloud motion between views (e.g. Moroney, et al., 2002; Muller et al., 2002; Kahn, et al., 2007). The stereo-matching algorithm is based on identifying similar spatial patterns of radiance contrast. The resulting height distributions are retrieved with an accuracy of $0.2-0.5 \mathrm{~km}$ and reported at $1.1 \mathrm{~km}$ horizontal resolution, which when plotted as histograms, tend to produce pseudo-profiles of plume vertical distribution in the vicinity of aerosol sources (e.g. Kahn, et al., 2007, 2008). This technique has been adapted specifically for the retrieval of the near-source smoke plume injection heights, and implemented as the MISR INteractive eXplorer (MINX) Software (Nelson, et al., 2008). MINX is an interactive tool that allows the user to specify the region over which stereo-matched heights are to be derived by digitizing the visible boundaries of the plumes and indicating the wind direction, whereupon the program performs the stereo matching and maps out the plume heights and wind vectors. Various studies have been conducted in different regions of the world using smoke plume-height data retrieved with MINX (e.g. Kahn et al., 2008; Val Martin et al., 2010; Mims et al., 2009; Tosca et al., 2011). Some of the main findings thus far include the following:

- Smoke plumes are not always injected into the near-surface atmospheric boundary layer, nor are they uniformly distributed vertically up to a peak altitude, as is sometimes assumed in modeling; rather, when sources are sufficiently buoyant relative to the near-surface atmospheric stability structure, smoke tends to concentrate in discrete layers of local atmospheric stability above the boundary layer (Kahn et al., 2007, 2008). Furthermore, based on initial analysis of MISR-derived plume heights in 
the Alaska-Yukon region during summer 2004, it was found that about $10 \%$ of wildfire smoke plumes reached the free troposphere.

- Based on the analysis of plume heights observed across North America from 2002 to 2007 (except 2003), it was deduced that plume heights are highly variable, ranging from a few hundred meters up to $5000 \mathrm{~m}$ at 11:00-14:00 local time. Statistically, the largest plumes are found over the boreal region with a median height of $\sim 850 \mathrm{~m}$, whereas the smallest plumes are found over cropland and grassland fires in the contiguous US, with a median height of $\sim 530 \mathrm{~m}$. A significant fraction (4-12\%) of plumes are injected above the planetary boundary layer (PBL), and most $(>83 \%)$ of those plumes located above the PBL are trapped within layers of relative atmospheric stability (Val Martin et al., 2010).

- Studies of plumes from grassland fires in the arid regions of western and central Australia, based on the MISR Standard Stereo height product as well as MINX data analysis, showed that most of the plumes studied stayed within the PBL, as expected, but a few of the cases studied actually rose above it, and some of those concentrated in higher layers of relative atmospheric stability above the boundary layer (Mims, et al., 2009).

- Studies of plumes from anthropogenic fires in tropical forests and peatlands of equatorial Asia (Borneo and Sumatra), also based on MINX data analysis, showed that mean MISR-derived plume heights were about $700 \mathrm{~m}$ on Borneo and $750 \mathrm{~m}$ on Sumatra during 2001-2009, with nearly all plumes confined to within $500 \mathrm{~m}$ of the atmospheric boundary layer.

Active remote sensing of smoke plumes is based on the analysis of Lidar return signal time sequences. The space-based lidar technique has been applied to smoke plumes mainly from the Cloud-Aerosol Lidar and Infrared Pathfinder Satellite Observations (CALIPSO) spacecraft using the Cloud-Aerosol Lidar with Orthogonal Polarization (CALIOP) dual-wavelength (532 and $1064 \mathrm{~nm}$ ) observations, which has a very narrow, single-pixel swath $(\sim 100 \mathrm{~m})$ that provides a curtain of vertical profiles beneath the orbital track (Winker, et al., 2007, 2010). As a result, it rarely observes the actual smoke injection process directly, but the technique is sensitive enough to profile thin aerosol layers downwind, where the plume has dissipated and is more widespread, making it a much bigger target. The uncertainty of lidar plume height retrieval is better than that of the passive method because of the precise nature of active remote sensing, although low signal-to-noise is a limiting factor for CALIOP, especially for daytime observations, mainly because of its large distance from the atmosphere as a satellite lidar (Winker, et al., 2010). Comparative case studies of CALIOP aerosol measurements relative to those of a ground-based Raman lidar showed an agreement in the aerosol layer top height to within $\pm 0.1 \mathrm{~km}$, and also found that CALIOP is capable of detecting 'aerosol at least up to $\sim 0.3 \mathrm{~km}$ from ground in cloud-free conditions' (Perrone et al., 2011, p.438). Analysis of CALIOP profiles of smoke aerosol layers in several regions of the world over a twomonth (July-August) period in 2006 indicated that in the tropical regions the smoke is generally within the PBL, whereas in the higher latitudes a small but significant proportion is above the PBL, although "cases with pyro-convection and/or direct injection to the free troposphere are not frequent" (Labonne et al., 2007). A similar study focused on agricultural burning in SW Russia and Eastern Europe during the 2006 - 2008 
fire season showed that almost $50 \%$ of the emitted smoke plumes were located above the PBL (Amiridis et al., 2010).

The two types of satellite measurement approaches (active and passive) are complementary, and when analyzed together in a synergistic way can provide more comprehensive information on the vertical structure of smoke injection and transport (e.g. Kahn et al., 2008). Joint analysis of MISR plume heights and CALIOP profiles in southeast Asian islands of Borneo and Sumatra, for example, showed that the mean smoke injection height from MISR was generally in the range of $700-750 \mathrm{~m}$, whereas the regional smoke layers that are not tied to their sources, as derived from both MISR and CALIOP, have layer top heights in the range of $1000-2000 \mathrm{~m}$ (Tosca et al., 2011).

Another unique type of satellite measurement that enables retrieval of plume vertical profiles under certain conditions employs limb-scattered spectral solar radiation measurement techniques. This was demonstrated using the Optical Spectrograph and Infrared Imager System (OSIRIS) instrument onboard the Odin satellite in the mapping of high plume injection into the stratosphere from the 2009 Australian 'Black Saturday' bush fires (e.g. Siddaway and Petelina, 2011). That study found that the plume reached an altitude range of $18-22 \mathrm{~km}$ and circumnavigated the globe within a span of $5^{\circ} \mathrm{S}-25^{\circ} \mathrm{S}$ latitude, lasting about 3 months, and with the plume peak radiance decreasing by $50 \%$ every 19 days.

\subsection{Space-based Constraints on Aerosol Microphysical and Optical Properties}

Knowledge of smoke-aerosol microphysical and optical properties can significantly improve the modeling of biomass-burning smoke impacts on air quality and climate. As aerosol remote sensing is based on optical measurements, typically, optical properties are somewhat more straightforward to retrieve from satellite observations than microphysical or chemical properties. The most common aerosol optical properties that can in principle be retrieved from satellite measurements include: spectral extinction/absorption/scattering coefficients $\left(\sigma_{\mathrm{e}}, \sigma_{\mathrm{a}}, \sigma_{\mathrm{s}}\right)$, aerosol index (AI), spectral aerosol optical depth or thickness (AOD or AOT or $\tau_{\mathrm{a}}$ ), Ångström exponent (Aexp or $\alpha$ ), spectral single-scattering albedo $\left(\omega_{0}\right)$, and refractive index $(\mathrm{RI})$; whereas the typical microphysical parameters include: particle shape, effective radius, particle composition, and some measure of size distribution. Currently operating satellite sensors provide some constraints on one or more of these properties (see Tables $1 \& 2$ ). The associated uncertainties on many of these retrieved parameters are not yet quantified, although in most cases, they are believed to be so significant that, at the current level of the technology, satellite retrievals of such microphysical properties are considered qualitative rather than quantitative, and are essentially a classification of aerosol type (e.g., Kahn et al., 2010). Detailed characterization of the essential microphysical properties of smoke particles is best done with in situ measurements at present.

One of the most direct ways that smoke aerosols have been identified and characterized has been to focus studies on specific regions and seasons where, through prior studies, the aerosols are known to be dominated by smoke. For example, such regionally-focused smoke-aerosol studies have been conducted during the biomass burning seasons in: African savanna (e.g. Ichoku et al., 2003b; Myhre et al., 2003), Australia (e.g. O’Brien and Mitchell, 2003), Brazil (e.g. Kaufman and Fraser, 1997; 
Kaufman et al., 1998b), Canada (e.g. Chung and Le, 1984; Ferrare et al., 1990; Hsu et al., 1999), Siberia (Cahoon et al., 1994), as well as several other regions. Although these region-focused methods provide important information about smoke distributions in regions and seasons where biomass burning is dominant, it is still necessary to have a generic way of distinguishing smoke from other aerosol types retrieved from satellite observations, to gain more knowledge about the places and times where these different aerosol types have the potential to mix with smoke. This will facilitate an accurate assessment of biomass burning smoke impacts on larger scales.

MISR can distinguish three to five aerosol particle size bins, two to four bins in single-scattering albedo, and spherical vs. non-spherical particles, under favorable retrieval conditions (e.g. Chen et al., 2008; Kalashnikova and Kahn, 2008; Kahn et al., 2010). Such variety of complementary optical and microphysical information can be used to distinguish smoke from dust in many practical situations (e.g. Liu et al., 2007a, b; Kalashnikova and Kahn, 2008; Dey and Di Girolamo, 2010). However, because the current MISR aerosol algorithm (version 22) does not contain analogs of dust and smoke optical mixtures, there are retrieval issues over the Sahel of Africa in seasons when both dust and smoke are present in significant amounts (e.g. Kahn et al., 2009). (These retrieval issues will be corrected in the next version of the MISR aerosol product.) MODIS assumes particle properties based on an aerosol climatology derived from AERONET data over land (e.g. Levy et al., 2010). However, like MISR, the current (Collection 5) MODIS aerosol product version also has issues when smoke and dust are mixed in the column. Nevertheless, MODIS derives aerosol fine-mode fraction (FMF) over water (e.g. Remer et al., 2005, 2008). Using FMF as a way of distinguishing coarsemode-dominated aerosol types such as mineral dust from fine-mode-dominated aerosol types such as smoke, Kaufman et al. (2005) developed a qualitative mapping of dust vs. smoke or pollution transport. That method included a series of empirical corrections to account for overlapping fine and coarse size distributions. OMI can identify ultraviolet (UV) absorbing species, such as smoke, over land and water, even above cloud, but has reduced sensitivity to aerosol near the surface (e.g. Ahn et al., 2008). Calipso-CALIOP utilizes the analysis of lidar ratios to distinguish between the main aerosol types (biomass burning, dust, oceanic, and urban/industrial pollution), as well as situations where aerosol and dust are mixed, categorized as 'polluted dust' (e.g. Cattrall et al., 2005; Omar et al., 2009).

\subsection{Satellite Monitoring of Biomass Burning Trace Gases}

A thorough literature review of biomass burning emissions by Andreae and Merlet (2001) catalogued a few identifiable particulate species, but also, several dozen trace gases whose relative concentrations in smoke typically span more than six orders of magnitude. In terms of total annual global emissions estimates, some of the most abundant trace gases in smoke (listed in order of decreasing amount) are: $\mathrm{CO}_{2}(\sim 13,400$ $\mathrm{Tg} / \mathrm{yr}), \mathrm{CO}(\sim 690 \mathrm{Tg} / \mathrm{yr}), \mathrm{NMHC}(\sim 49 \mathrm{Tg} / \mathrm{yr}), \mathrm{CH}_{4}(\sim 39 \mathrm{Tg} / \mathrm{yr}), \mathrm{N}_{2}(\sim 26 \mathrm{Tg} / \mathrm{yr}), \mathrm{NO}_{\mathrm{x}}$ $(\sim 21 \mathrm{Tg} / \mathrm{yr}), \mathrm{H}_{2}(\sim 15 \mathrm{Tg} / \mathrm{yr})$, Methanol and Acetic Acid $(\sim 13 \mathrm{Tg} / \mathrm{yr})$ each, and $\mathrm{NH}_{3}(\sim 10$ $\mathrm{Tg} / \mathrm{yr}$ ), whereas others are quantified in single digits and fractions of $\mathrm{Tg} / \mathrm{yr}$ (Andreae and Merlet, 2001). For example, based on airborne measurements of over 40 trace gas species emitted in fresh smoke in Canada during the 2008 Arctic Research on the Composition of the Troposphere from Aircraft and Satellites-B (ARCTAS-B) intensive field campaign 
(June-July, 2008), it was found that $\mathrm{CO}_{2}, \mathrm{CO}$, and $\mathrm{CH}_{4}$ alone comprised $98.6 \%$ of the measured carbon released from fires (Simpson et al., 2011). Many of these fire-emitted trace gases have significant climate and/or air-quality implications. For instance, after water vapor $\left(\mathrm{H}_{2} \mathrm{O}\right), \mathrm{CO}_{2}$ followed by $\mathrm{CH}_{4}$ are two of the most important atmospheric greenhouse gases (e.g., Frankenberg et al., 2005a), with the atmospheric-heating efficacy of $\mathrm{CH}_{4}$ per unit weight being over 25 times greater than that of $\mathrm{CO}_{2}$ (e.g. Schneising et al., 2009); $\mathrm{CO}$ and $\mathrm{NO}_{\mathrm{x}}$ are two of the six 'criteria pollutants' identified by the US EPA as being harmful to public health and the environment (e.g. Koren, 1995).

Fortunately, many of the above-mentioned most abundant biomass-burning emissions species are presently measurable by remote sensing, but others are not. Although the NASA Orbiting Carbon Observatory (OCO) mission, dedicated to measuring carbon dioxide $\left(\mathrm{CO}_{2}\right)$, failed to reach orbit due to launch failure in 2009 , a replacement mission, OCO-2 is scheduled for launch in 2013. In the meantime, $\mathrm{CO}_{2}$ is being retrieved from Envisat-SCIAMACHY (e.g. Buchwitz et al., 2005a,b, 2006, 2007), Aqua-AIRS (e.g. Chahine et al., 2008), and the Greenhouse gases Observing SATellite (GOSAT) (Butz et al., 2011). Carbon monoxide (CO) is one of the few gases whose remote sensing retrieval started in the earliest days of satellite earth observation, including from measurements conducted from space-shuttle missions (e.g. Reichle et al., 1986). Currently, CO is routinely retrieved either in the form of total-column amount or as profiles from TerraMOPITT (e.g. Deeter et al., 2003; Edwards et al., 2006), Aqua-AIRS (e.g. McMillan et al., 2005), Aura-TES (e.g. Beer et al., 2001), Envisat-SCIAMACHY (e.g. Frankenberg et al., 2005b; Buchwitz et al., 2005b, 2006), and MetOp-IASI (e.g. George et al., 2009). Methane $\left(\mathrm{CH}_{4}\right)$, like $\mathrm{CO}$, is retrieved from various satellite sensors, sometimes in conjunction with $\mathrm{CO}$ or $\mathrm{CO}_{2}$ (e.g. Deeter et al., 2003; Buchwitz et al., 2005b, 2006; Frankenberg et al., 2005a, 2006; Schneising et al., 2009; Butz et al., 2011). Similarly, the nitrogen oxides $\left(\mathrm{NO}_{\mathrm{x}}\right)$ are retrieved in conjunction with some of the aforementioned trace gases from different satellite sensors, including the Global Ozone Monitoring Experiment (GOME) instrument aboard the ERS-2 satellite (e.g. Spichtinger et al., 2001) and the Halogen Occultation Experiment (HALOE) instrument (e.g. Park et al., 2004) onboard the Upper Atmosphere Research Satellite (UARS) that was decommissioned in 2005.

Several of the above-mentioned trace gases (e.g. $\mathrm{CO}, \mathrm{CH}_{4}, \mathrm{NO}_{\mathrm{x}}$, and hydrocarbons) that are directly emitted from biomass burning are precursors for tropospheric ozone $\left(\mathrm{O}_{3}\right)$ formation (e.g. Jonquières et al., 1998; Thompson et al., 2001). Although ozone is a secondary product of biomass burning, its role as one of the 'criteria pollutants' makes it an important consideration in this discussion. Satellite retrieval of ozone has a long history (e.g. Thompson et al., 2001; Edwards et al., 2003). It is routinely retrieved from many satellite sensors, both past and current, including the TOMS series, the GOME series, OSIRIS, and OMI (see Tables 2 and 4b).

The uncertainty of fire-emitted trace gas measurements from satellites varies, depending on species and sensor characteristics. Since there are quite a number of such sensors and numerous trace gases, it is beyond the scope of this paper to review the uncertainties in detail, as such a review can take up an entire paper, even if it is focused on the most prominent gases, such as $\mathrm{CO}_{2}, \mathrm{CH}_{4}$, and $\mathrm{CO}$ (e.g. Schneising et al., 2008, 2009; Yurganov et al., 2010, 2011). However, as an illustration of the current level of uncertainty in this domain, Yurganov et al. (2011) evaluated total column (TC) CO retrieval from three space-based infrared sounders (MOPITT, AIRS, and IASI) against 
concurrent $\mathrm{CO}$ measurements from 'ground-based spectrometers in Moscow and its suburbs during the forest and peat fires that occurred in Central Russia in July-August 2010'. One of the major known issues highlighted is that of inadequate sensitivity of the satellite CO measurements in the PBL, which is a major problem in studying biomass burning emission rates and air quality. The study indicated that: 'On certain days the $\mathrm{CO}$ effective TC retrieved from data of space-based sounders was 2-3 times less than those obtained from the ground' (Yurganov et al., 2011, p. 7925). After compensating for the missing $\mathrm{CO}$, which is the amount by which the measurements from ground-based spectrometry exceeds those from the satellite-based sounders, they estimated that this corrected satellite-based $\mathrm{CO}$ had a final uncertainty of $\sim 30 \%$ for the Russian fires. On the other hand, Schneising et al. $\left(2008\right.$, p. 3827; 2009, p. 443) referring to $\mathrm{CO}_{2}$ and $\mathrm{CH}_{4}$, indicated that 'SCIAMACHY on ENVISAT is the first satellite instrument whose measurements are sensitive to concentration changes of the two gases at all altitude levels down to the Earth's surface where the source/sink signals are largest'. They further explained part of their analysis method by stating: 'The greenhouse gas columns are converted to dry air column-averaged mole fractions, denoted XCO2 (in ppm) and XCH4 (in ppb), by dividing the greenhouse gas columns by simultaneously retrieved dry air columns.' By comparing XCO2 with Fourier Transform Spectroscopy (FTS) measurements at two northern hemispheric mid-latitude ground stations, they found a precision of $1-2 \%$, a systematic low bias of $\sim 1.5 \%$, and a relative accuracy of $1-2 \%$ for monthly averages at a spatial resolution of about $7^{\circ} \times 7^{\circ}$ (Schneising et al., 2008). Also, by comparing the satellite XCH4 to that of the TM5 model, which had been 'optimally matched to highly accurate but sparse methane surface observations', after accounting for a systematic low bias of $\sim 2 \%$, they found agreement with TM5 to be typically within 12\% (Schneising et al., 2009).

\subsection{Smoke Particulate and Gaseous Emission Source Strengths}

Emission source strength is the quintessential ingredient for detailed study/modeling of the atmospheric loading, transport, and the impact of diverse fire emission species. Despite advancements in satellite measurement techniques during the last few decades, and the abundance of remote-sensing data products, emission source strength still cannot be measured directly from space because of the associated spatial and temporal sampling limitations, the inherent ambiguity in resolving mixing from different sources, and the underlying multi-species composition. Therefore, source strength must be estimated using indirect approaches, such as from bottom-up estimates of fuel type and consumption (e.g., Eq. (1) and (2)). Past methods of estimating fire emissions were based on proxy information such as statistics of vegetation, population, rainfall, and agricultural practices, which were grossly inadequate in terms of spatio-temporal coverage, efficiency, and accuracy (e.g. Seiler and Crutzen, 1980; Crutzen and Andreae, 1990; Andreae, 1991; Hao and Liu, 1994). Due to the inadequacy of emission source-strength parameterization in climate and other atmospheric models, the overall effects of fires and emitted smoke constituents on climate and air quality are still poorly understood. Therefore, there is a need to develop more effective satellite products in these areas (e.g. Scholes 1995; Scholes and Andreae, 2000; Andreae and Merlet, 2001). 
Present satellite-based methods for estimating smoke-aerosol and trace-gas emissions from fires often use post-fire burned areas (e.g., Hoelzeman et al., 2004; Ito and Penner, 2004; Kasischke and Penner, 2004; Korontzi et al., 2004; Palacios-Orueta et al., 2004). Typically, the burned areas are substituted for $A$ in Eq. (2), which is then used in conjunction with Eq. (1) and the associated parameters to simulate the emissions. Incidentally, satellite burned-area estimates are still saddled with much uncertainty, and as they are normally derived after fires have burned out, they cannot meet near-real-time air-quality applications requirements. Alternatively, fire pixel counts from satellite observations are used as proxies for estimating $A$, which are then used for emissions estimates (e.g. Kaufman, 1990; Chin et al., 2002; Duncan et al., 2003; Zhang and Kondragunta, 2008; Reid et al., 2009). However the use of satellite fire pixel counts imposes even more uncertainty than direct estimates of $A$, because it does not reflect any quantitative fire characteristics that actually determine the smoke emission rate, such as size, strength or intensity, fuel loading, smoldering/flaming fractions, and smoke injection height. Besides, they do not take into account the fires that may have been missed because of cloud cover or other factors, although in certain cases efforts are made to compensate for such omissions (e.g. Giglio et al., 2003b). On the other hand, the burned area products can implicitly include any observable areas that are burned over a time period of up to a few months or more. Furthermore, fire pixel counts cannot be consistent across multiple satellite sensors with different spatial resolutions or even within the same sensor when there is significant variation of ground pixel size within the same image scene, as in the case of most geostationary and broad-swath polar orbiting satellite sensors, such as MODIS, AVHRR, GOES, and SEVIRI.

Various emission inventories based on satellite active fire pixel counts and/or postfire burned areas have been developed during the last decade. Of such datasets, the one most widely used in global models is the Global Fire Emissions Database (GFED), which was first established in the mid-2000s, and is currently in its third version (van der Werf et al., 2003, 2006, 2010). GFED is based on burned areas, fire pixel counts, and plant productivity derived from the MODIS sensor. For pre-MODIS time periods, data from other satellite sensors, such as active fire pixel counts from the Tropical Rainfall Measuring Mission's (TRMM) Visible and Infrared Scanner (VIRS) and the Along-Track Scanning Radiometer (ATSR), as well as plant productivity data derived from AVHRR, are used to estimate the biomass burned and emitted species. Another satellite-based fire emissions product that is currently used by the community is the Fire Locating and Modeling of Burning Emissions (FLAMBE), developed through a joint project by the U.S. Navy, NASA, NOAA, and University of Maryland (Reid et al., 2004, 2009). FLAMBE uses the diurnal observations of active fire hotspots from the GOES geostationary satellite imagers, processed with the NOAA/NESDIS operational Wild-Fire Automated Biomass Burning Algorithm (WF_ABBA) for the western hemisphere, and the near real-time MODIS fire products from the University of Maryland/NASA fire remote-sensing team for everywhere else. Emission fluxes are then calculated using a source function that takes into account the biomass density, burn completeness, and emission factors. Regional-scale studies in the Amazon Basin, conducted within the context of FLAMBE, revealed that emissions biases due to satellite active-fire location errors were in the range of $+3 \%$ to $+19 \%$ for MODIS and $+6 \%$ to $+39 \%$ for GOES (Hyer and Reid, 2009). Comparisons of PM2.5 emissions between GFED and FLAMBE are 
typically within a factor of two to three, and the magnitude of the differences varies with region (Reid et al., 2009). Apart from GFED and FLAMBE, there are quite a few other satellite-derived emissions data sets that are either still in the research mode/under development or intended for special purposes within a limited region/time period (e.g. Duncan et al., 2003; Pouliot et al., 2008; Roy et al., 2008b; Liousse et al., 2010; Urbanski et al., 2011).

In an effort to reduce the sources of uncertainty and employ more quantitative satellite measures to estimate biomass-burning emissions and rates, scientists are directing attention to the use of FRP and FRE. A linear relationship of the form in Eq. (1) linking FRP (or FRE) to smoke emissions has been developed, whereby $M_{x}$ can be replaced with FRP and $E F_{x}$ is replaced with empirically derived FRE-based emission coefficients to generate smoke-aerosol emission rates (e.g. Ichoku and Kaufman, 2005). If $M_{x}$ is replaced with FRE (instead of FRP) the total emission corresponding to the period covered by the FRE is generated. However, this is subject to both the intrinsic uncertainty of FRP measurement and that emanating from the observation frequency and time-integration process used to derive FRE. Furthermore, although small fires have been used at the laboratory scale to demonstrate that the FRE to burned-biomass relationship is not significantly dependent on vegetation type and fuel load (Wooster et al., 2005), there remains some uncertainty as to how that linear relationship translates to landscape-scale fires that are measured at the typical $1-\mathrm{km}$ to $4-\mathrm{km}$ pixel sizes of large-coverage satellite sensors such as MODIS, SEVIRI, or GOES.

The modified Eq. (1) relationship linking emissions to FRE has been verified and indirectly validated in the laboratory by mimicking corresponding satellite measurements at a small scale (Ichoku et al., 2008b). Although the use of FRP and FRE for emissions estimations does not compensate for missed observations (as in the case of pixel counts, it offers a set of new advantages: (i) they are quantitative sub-pixel measures related to important biomass burning variables; (ii) they transcend intra- and inter-sensor spatial variability; (iii) they are simple to use and avoid complications involved in estimating the variables in equation (2); and (iv) they can be applied to derive emissions in near real time, as would be appropriate for use in air-quality monitoring and forecasting. However, these are presently only potential advantages, and will be quantitatively meaningful when the various uncertainties associated with this method are well constrained or at least understood and clarified with associated error budgets. In the meantime, the scientific community is increasingly exploring the potential applicability of satellite FRP measurements in various areas of study. For instance, FRP-based emission approaches have been successfully tested for air-quality applications in the US (e.g. Jordan et al., 2008), Canada (e.g. Henderson et al., 2008), and Europe (e.g. Sofiev et al., 2009), and has also been investigated for general global emissions research and applications (e.g. Vermote et al., 2009). Furthermore, satellite FRP measurements have begun to be implemented experimentally in certain global models, such as the NASA Goddard Earth Observing System-version 5 (GEOS-5) model, which is hosting the development and evaluation of a new FRP-based emissions dataset referred to as the Quick Fire Emissions Database (QFED, e.g. van Donkelaar et al., 2011). Also, a more recent study by Kaiser et al. (2012) demonstrates the assimilation of the FRP measurements from MODIS in the Global Fire Assimilation System (GFASv1.0) operated under the Monitoring 
Atmospheric Composition and Change (MACC) project within the European Centre for Medium-Range Weather Forecasts (ECMWF). Nevertheless, emissions based on FRP and FRE are still subject to significant uncertainty that propagate from these and other parameters. For instance, use of FRP-based burned biomass with literature-based emission factors within GFASv1.0 was found to yield particulate matter amounts requiring a boost by a factor of $2-4$ in order to agree with expected global distributions of organic matter and black carbon (Kaiser et al., 2012). However, it is not clear how much of the uncertainty stems from the satellite FRP measurement, the conversion factors from FRP to burned biomass, the literature emission factors, the injection height assumptions, and other model parameterizations. Therefore, more research is still needed to truly quantify the absolute magnitudes and sources of these uncertainties.

\subsection{Satellite Monitoring of Fire-related Meteorological Conditions}

Satellite-based constraints on the vertical distribution of smoke were discussed in Section 2.4, because smoke injection height has broad implications for smoke dispersion, boundary layer ventilation, and the initiation of downwind transport. However, it is recognized that meteorological factors are also important for the formation and evolution of smoke plumes, beginning with temperature and humidity conditions in the source regions, typically covered under "fire weather" (e.g. Haines, 1988; Potter et al., 2008) and continuing with downwind horizontal advection, vertical mixing, hydration, and precipitation that govern the transport and ultimate deposition of smoke particles.

Satellites provide some information that can be used to derive special indices for forecasting fire potential, such as the Alaska Fire Potential Index (e.g. Burgan et al., 1998; Peterson et al., 2010). Such satellite input information may include, for instance, temperature and humidity profiles from Aqua-AIRS (e.g. Susskind et al., 2003; Chahine et al., 2006), rainfall from the TRMM and other satellite sensors (e.g. Adler et al., 2000), and vegetation indices, such as the normalized difference vegetation index (NDVI) from MODIS, AVHRR, or other applicable sensors (e.g. Tucker et al., 2005). On the other hand, satellites currently do not provide measurements of the local meteorological conditions that drive fire spread rate and near-fire smoke plume dynamics and entrainment. This is because such fire-behavior and source-emissions features are characterized by high spatial and temporal variability, and are logistically too complex to follow from satellites, which are limited by the fact that those providing high spatialresolution can offer only very low temporal resolution and vice versa.

Regarding downwind transport and deposition, satellite observations are primary resources, as they can monitor the distribution of smoke plumes over large areas (e.g. Prins and Menzel, 1992). An example of this application is implemented in the NOAA/NESDIS Hazard Mapping System (HMS), where the plume transport can be visualized on movie loops based on the relatively high temporal-frequency sequence of the Geostationary Operational Environmental Satellite (GOES) imagery (e.g. Schroeder et al., 2008c). This capability is not entirely limited to geostationary satellite sensors, but is also applicable to a certain extent using wide-swath daily repeat-pass satellite sensors. For instance, a history of smoke in transit can be reconstructed from changes in the smoke-plume total-column AOD or CO measurements from satellite (e.g. Colarco et al., 2004; McMillan et al., 2008). 


\section{Modeling}

Given that satellite observations are essentially snapshots that represent only the instantaneous state of the observed scene, modeling is necessary to establish the relevant dynamics and interconnections associated with a phenomenon of interest. Accounting for fire and smoke effects on climate and air-quality requires different scales of modeling in order to adequately capture the process-level characteristics of the emission, transport, and interactions of the fire-generated heat fluxes and smoke constituents. In this section, we discuss three of the modeling activities that are most relevant to biomass burning: plume-rise, transport, and inverse modeling.

\subsection{Plume-rise modeling}

Early models of wildfire plume rise evolved from cumulus convection parcel modeling (e.g., Simpson and Wiggert, 1969). Buoyant energy flux, ambient atmospheric stability structure, and entrainment, which are among the main factors involved in cumulus convection modeling, are the primary physical considerations for smoke plumes. However, in some cases, the ambient wind profile and latent heat release are added complications for smoke plumes. Efforts at modeling plume rise range from scaling laws and simple diagnostic parcel models to fully prognostic two- and three-dimensional finite-difference numerical simulations (e.g., Cogan, 1985; Toon et al., 1988; Arya and Lape, 1990: Heikes et al., 1990; Luderer et al., 2006; Trentmann et al., 2002, 2006; Freitas et al., 2006, 2007).

Constraining these models quantitatively with observations is a persistent challenge. The most detailed information comes from surface-based and airborne plume measurements (e.g., Cofer et al., 1988; Radke et al., 1995; Riggan et al., 2004; Cahill et al., 2008; Cammas et al., 2009; Burling et al., 2011; Yokelson et al., 2011; Gatebe et al., 2012), but there are few such quantitative measurements of wildfires, especially given the diversity of fire types, and even fewer cases where radiative, dynamical, and thermodynamic structure were constrained both inside the plume and in the ambient atmosphere. The buoyant energy flux is highly variable among different fire types as well as within most active burning regions, and this quantity is difficult to measure directly. For use as a constraint on plume-rise models, it is only loosely related to the radiant energy flux (i.e. FRP) routinely observed from space (Section 2.3 above), due to uncertain fire emissivity values, sub-pixel variability in fire occurrence and properties, and overlying smoke opacity, each of which is itself poorly constrained by observations in most cases. Atmospheric stability structure is usually obtained from general circulation models, for which the largest uncertainty relative to plume-rise modeling is the rapidly varying daytime vertical extent of the atmospheric boundary layer (e.g., Val Martin et al., 2010). Entrainment is yet more difficult to constrain, as it depends upon small-scale interactions between the plume(s) and the surroundings. Advanced parameterizations are not able to adequately account for even model-based anisotropic turbulent mixing at smaller scales (e.g., Herzog et al., 2003). Yet even the relatively simple approach of scaling entrainment according to an assumed plume cross-sectional area (e.g., Freitas et. al., 2007), which should represent the situation well if burning is uniform over the assumed fire area, has limitations in the more typical situation where the convective elements are fragmented. 
As such, plume-rise modeling to date has achieved qualitative success in reproducing observed smoke injection patterns, provided satellite-measured FRP is scaled up by factors between about two to ten to obtain sufficient buoyant energy flux (e.g., Kahn et al., 2007). Advances in this area will likely require detailed, near-simultaneous field measurements of all the relevant factors, on spatial scales fine enough to resolve individual flaming and smoldering fire elements. The application of plume-rise models for aerosol transport modeling is discussed in the next section.

\subsection{Transport modeling}

Global and regional models are often used to simulate biomass burning emissions and transport in order to assess the environmental impacts of biomass burning (e.g. Wang and Christopher, 2006; Wang et al., 2006; Hodzic et al., 2007; Turquety et al, 2009; Longo et al., 2010). Two critical inputs to the model are (1) emission strengths of trace gases and aerosols and (2) injection height. Whereas emission strengths determine how much material is released to the atmosphere, the injection height regulates the spatial extent of smoke plume transport.

As described in previous sections, emission of trace gases and aerosols is generally calculated from Eq. (1) and (2) as a function of burned area, dry mass burned, and emission factor for each species. Despite significant progress made during the past few decades in quantifying them, facilitated by advancement in satellite observations of fires, burned area, plume structure, and smoke constituents, there are still large uncertainties in each term in Eq. (1) and (2). For example, both the magnitude and spatial distribution of estimated burned area ( $A$ in Eq. (2)) can vary considerably, sometimes by orders of magnitude, between a fire-counts-based approach (e.g., Giglio et al., 2006) and a reflectance-based burn scar detection (Roy et al., 2008a), and among different satellite sensors (Roy and Boschetti, 2009). The fuel load ( $B \times \alpha$ in Eq. (2)) estimated using different methods also deviates by more than a factor of 2 , and the emission factor ( $E F_{x}$ in Eq. (2)) for any particular biome can differ significantly in the literature, due to limited field measurements. The combination of these uncertainties results in large uncertainty in the calculated biomass burning emission strength. Fig. 3 shows an example of burnedarea and dry-mass differences between a few different datasets. Such a large diversity of estimated biomass burning emissions greatly dampens our confidence in assessing the environmental and climate impacts of biomass burning.

Satellite observations of trace gases and aerosol optical depth (AOD) near biomass burning source areas can be used to constrain the emission strength when other sources, such as pollution and dust, are much smaller compared to the fire emissions. Figure 4 demonstrates the AOD simulated with a transport model, the Goddard Chemistry Aerosol Radiation and Transport (GOCART) model, using different combinations of burned area, biomass consumed, and emission factors over Russia for the fire case of July 20, 2006, and the results are compared with the MODIS-derived spatial distribution of plume AOD. In this case, the maximum AOD simulated by the model varies by a factor of 5 with different emission estimates, and the MODIS AOD data indicates that the emission obtained from fire-counts-based burned area and high emission factors best match the observations (Petrenko et al., 2011). 
Another subtle issue regarding modeling biomass burning emission is the diurnal variation of fire intensity. In most regions, burning intensity peaks between noon and early afternoon, as estimated from geostationary satellite observations (e.g. Prins et al., 1998; Zhang et al., 2008) and field experience, especially for agriculture-related burning that typically has a very large diurnal cycle. However, because of the limited data available for describing the diurnal cycles of fire emissions, most global models use daily to monthly averaged biomass burning emissions. Recently, Vermote et al. (2009) parameterized the diurnal cycle of fire emissions in different ecosystems based on the statistics of the ratio of FRP from Terra and Aqua MODIS and geostationary satellite observations at certain locations. Such diurnally resolved fire emission datasets should be adapted into chemical transport models to improve the time-resolved fire events, which is particularly important for air quality forecast and management.

With respect to the biomass burning emission injection height, most global or regional transport models put these emissions within the PBL. Statistically, this assumption represents the most common emission altitude from biomass burning, and the plume released in the PBL can be transported upward by convective processes, to bring some of the smoke species into the free troposphere. However, the absence of specific consideration of additional buoyancy generated by the fire would result in an underestimation of the injection height, and consequently the plume altitude and transport efficiency, since in the free troposphere, where the removal processes are less efficient, pollutants are advected away from the source region faster than in the PBL. This is especially the case for big fires. For example, using global chemistry transport models and trajectory analysis, Colarco et al. (2004) showed that the observed downwind atmospheric concentrations of the emissions from the July 2002 Canadian wildfires in the northeastern United States were best reproduced by injection at 2-6 km. Similarly, Leung et al. (2007) reported that, in the case of the 1998 Siberian fires, injecting $60 \%$ of the emissions at $3-5 \mathrm{~km}$ altitude improved agreement with $\mathrm{CO}$ surface and column measurements. As described in the previous section, more sophisticated plume rise models have been developed to explicitly take into account the heat flux (often represented by FRP), fire size, fuel moisture, and meteorological conditions (relative humidity, temperature, wind speed, and atmospheric stability). Using a 1-D plume-rise model imbedded in a regional transport model, Freitas et al. (2007) demonstrated that explicitly modeling the plume-rise process significantly improved the model-simulated vertical profiles of $\mathrm{CO}$ concentrations over the Amazon, whereas they were overestimated in the lower troposphere but underestimated in the mid troposphere when plume rise was not included. However, as pointed out in the previous section, the input parameters for the plume rise model are highly variable and difficult to quantify. At present, the biomass injection height for simulating large fires usually has to be adjusted based on the plume extent and/or vertical profiles observed by satellite and in-situ instruments on a case-by-case basis.

\subsection{Inverse Modeling}

A different method to constrain the biomass burning emissions using satellite and other observations is through "inverse modeling". In this approach, the best description of the atmospheric state of the species (e.g., trace gases or aerosols), either from satellite and other observations or from model assimilation of observations, is used to "retrieve" 
emissions, by applying the adjoint method to invert a chemistry transport model (e.g. Henze et al., 2007; Dubovik et al., 2008; Kopacz et al., 2009). In the inversion process, a chemical transport model can be viewed as a numerical operator that acts on a vector of parameters, including physical and chemical processes, to yield an estimate of the evolved atmospheric distributions. In general, the parameters in a chemistry transport model are emissions, boundary conditions, initial conditions, transport, chemical reactions, and dry and wet deposition; for aerosols, the additional size distribution and light extinction efficiency parameters are also included. In theory, all these parameters could be optimized simultaneously. However, most inverse modeling studies have focused on emission, because it is the most sensitive and critical parameter (e.g. Henze et al., 2009; Dubovik et al., 2008). Fig. 5 illustrates the inverse modeling concept for retrieving aerosol emissions with AOD observations from satellite and the GOCART model (Dubovik et al., 2008). Using the MODIS fine mode AOD products, Dubovik et al. (2008) produced a map of daily global fine mode aerosol sources, mostly BC, OC, and sulfate from pollution and biomass burning, in 2001 (Vermote et al., 2009). These products were used in turn to derive the emission coefficients for different biomes, based on the MODIS FRP (Vermote et al., 2009). Inverse modeling represents one of the closest connections between observations and models.

\section{Measurement to Modeling Synergy}

Although satellite observations provide synoptic overviews of fire/smoke scenes, a comprehensive understanding of the fire phenomenon and various impacts cannot be obtained from satellite observations alone. The more intricate issues in Climate and Airquality studies, involving the establishment of spatial and temporal continuity, are better addressed with the help of models. Satellite data yield significant benefits in advancing these studies by providing model inputs and validation for model results. However, there is the question of compatibility between satellite data and input requirements of models.

Regarding the issue of spatial and temporal compatibility between models and satellites, models expect to analyze entire fires, whereas satellites provide pixilated observations of fires. Regardless of whether a fire event is observed as a single pixel or a cluster of these, the pixels identified as containing fires are hardly ever fully burning. This can create significant gaps in both fire and burned-area satellite products, relative to model input parameter expectations. On the other hand, many climate models have much coarser spatial resolution (typically on the order of $1^{\circ}$ longitude and latitude) than typical satellite fire products (typically on the order of $1 \mathrm{~km}$ ), although such models employ special treatment to represent fire emissions from point sources (e.g. Freitas et al., 2007). The temporal compatibility issues stem from the fact that whereas models require information on the burning over a finite period of time that can vary from fractions of an hour to a day or even to the duration of an entire multi-day fire event, satellites provide snapshots interspersed by time intervals varying from several minutes (for Geostationary satellites) to several days (for polar orbiting satellites). The larger temporal gaps generally necessitate interpolation by the models, which can involve a wide variety of assumptions. For instance, Chen et al. (2009) studied the sensitivity of CO and aerosol transport modeling to the temporal and vertical distribution of North American boreal fire 
emissions, and found that the timing and injection height of biomass burning emissions are among the largest uncertainties when modeling forest fire effects. The mismatch in temporal scales between satellite observations and model requirements can probably be mitigated to some extent by having multiple, evenly distributed, Geostationary satellites providing continuous coverage around the earth, each being able to measure fires accurately at well coordinated, short time intervals (preferably $\leq 15 \mathrm{~min}$ ). With certain limitations, this geostationary satellite configuration is almost already available with the American GOES-East and GOES-West series, the European Meteosat Second Generation (MSG), the Japanese MTSAT series, and the Korean COMS satellite series. The limitations include the fact that being primarily designed for weather monitoring, the geostationary satellite footprint is typically coarse, with pixel sizes in the range of $3-5$ $\mathrm{km}$ near the sub-spacecraft point and much poorer toward the edges of the coverage area, resulting in massive omissions of small to medium sized fires that are the most abundant, especially in non-forest regions. Furthermore, even the fires that are detected are not necessarily measured accurately in the quantitative sense of retrieving the fire sub-pixel temperature, area, and FRP, as is possible from polar-orbiting satellite sensors much closer to Earth's surface. Fortunately, some of the future geostationary satellite missions, such as GOES-R, are considering fire measurements more seriously and are not only paying closer attention to sensor fire-measurement accuracy design requirements than in the past, but are also making an effort to increase the spatial resolution and temporal sampling frequency (e.g. Schmit et al., 2008). If such fire-measurement-friendly initiatives propagate through other geostationary operators in developing future missions, the future will be bright for quantitative fire monitoring. The gaps that will remain in the polar regions (particularly toward the Arctic, where Boreal forest and peat fires are common) can be covered by polar-orbiting satellite sensors such as Terra- and AquaMODIS and NPP-VIIRS, that provide more frequent overpasses at high latitudes. Under the foregoing scenario, the satellite/model spatial/temporal mismatch will be significantly reduced.

Apart from the spatial and temporal issues, there are also quantitative differences between the satellite measurements and model variables themselves. Most earlier and current models were originally developed on the basis of traditional in situ measurements, and their parameterizations were based on geophysical variables, most of which are not directly measurable by current remote sensing techniques that essentially derive few geophysical parameters from radiance measurements. Table 5 is a list of typical model inputs and their closest corresponding satellite-measured equivalents. Most of the model input variables do not have homologues among satellite observations, whereas those that do have corresponding measures that do not represent the same quantity and often require additional interpretation. As such, most satellite products are not exactly the type of data required by models. For instance, whereas models require burned biomass amounts as well as fire-released latent and sensible heat to predict smoke emissions and injection heights, remote sensing provides burned areas, and radiative heat release rates, which must be transformed to parameters that models can ingest. 


\section{Conclusions and Perspectives for Future Research}

Satellite remote sensing of fires and fire-related features, including energy release rates, burned areas, and the spatial distribution and optical and physical characteristics of the smoke particulate and gaseous constituents, has enabled a major advancement in the state of knowledge on this subject matter within the past few decades. First, it has provided an overview of fire occurrence throughout the globe, thereby facilitating the development of clear global and regional inventories of fire activity, as well as maps of major emission source locations, relative concentrations, injection heights, and transport of smoke around the globe, compared to other sources of aerosols and trace gases. This has made model parameterization of smoke emissions more realistic, resulting in improved smoke trajectory and atmospheric residency time predictions, and better representation of smoke interactions with clouds and radiation.

Despite these advances in remote sensing in general and satellite fire and smoke characterization in particular, there remain large uncertainties in the characterization of fire activity, as well as their emissions and impacts. Many aspects of fires are still not being quantified adequately or even at all to satisfy basic climate or air-quality modeling requirements. First, each polar orbiting satellite having fire-sensing capability can observe fires at a given location no more than once or twice per day. As such, only fires that are actively burning during satellite overpass times can be observed, whereas those that start and end between satellite overpasses cannot be accounted for. Such shortduration fires are typically rampant in grasslands and agricultural areas where slash-andburn is practiced. Although geostationary satellites allow observation at much higher (sub-hourly) frequency, because of their typically large pixel footprints relative to those of the polar orbiters, they miss small to medium size/intensity fires even when these are actively burning during observation times (e.g. Wooster et al., 2005; Roberts et al., 2005; Freeborn et al., 2009). Even when fires are observed, there may be significant uncertainty in the quantitative measurement of their FRP values, for example, because of intrinsic measurement uncertainties as well as possible atmospheric scattering and absorption of the fire-emitted thermal radiation, which tend to reduce the top-of-atmosphere signal. The result is a tendency to underestimate fire occurrence and activity. The use of interpolation or extrapolation approaches helps bridge the spatial and temporal gaps in the fire observations, but also adds to these uncertainties.

Burned area methods can help bridge fire activity gaps, as burned areas implicitly include areas consumed during the period leading up to the observation. However, satellite burned-area mapping has its own intrinsic uncertainties. First, for many satellite sensors, burned areas are mostly smaller than the pixels within which they occur, and subsequent aggregation of multiple sub-pixel burned areas can result in large overestimation of actual burned areas. In addition, burn severity may be extremely heterogeneous in a given burned area, and estimation of burned biomass based on assuming uniform degrees of burn can also introduce large uncertainties. Besides, burned area inventories usually lack information needed to estimate emission rates at the exact dates and times of burning, without which it is impossible to determine the history of smoke constituent emissions, their dispersal and transport trajectories, and their atmospheric residence times (e.g. Fleming et al., 2012). Both the spatial and temporal information are as important as the physical and radiative information about biomass 
burning and their associated emissions for accurately quantifying how they impact the air quality, weather, and the radiative budget that contributes eventually to climate change.

Satellite observation of smoke constituents is also saddled with uncertainty. First, in the satellite measurement process, there is intrinsic difficulty in distinguishing radiances originating from the atmospheric particulate or gaseous species of interest with those emanating from the surface background and other surface or atmospheric features. Although there are ways to compensate for such effects, these methods involve many assumptions. Even if a targeted atmospheric particulate or gaseous species is measured accurately from satellite, in cases where there is mixing of similar species from different sources, such as smoke and vehicular emission aerosols or $\mathrm{CO}$, it is often difficult to perform source apportionment in order to determine their relative impacts. Furthermore, many smoke constituents, including particulate matter and some trace gases that are normally detected by reflected solar ultraviolet and/or visible light, cannot be measured at night. Although this may not be a major gap for climate studies, it is for air quality.

Recent advances in measurement capability and coverage should not be minimized, however, and further advancement in satellite remote-sensing technology can address many of the limitations outlined above. Other gaps can be filled using alternative approaches, such as ground-based and airborne measurements. The development of geostationary observations having relatively high (sub-kilometer) spatial resolution would represent a significant advance in fire remote sensing, allowing active fires to be measured at adequate spatial and temporal resolutions to capture the most important fire sizes/intensities throughout the diurnal cycle. Improvement in other remote sensing instrumentation and algorithms could reduce current uncertainties in burned area estimation, plume profiling, and smoke constituent characterization. Furthermore, effort is needed to make satellite retrievals and model input requirements more compatible, by: (1) developing new satellite measurements that meet model input-data requirements with fewer assumptions, and (2) creating new models or adapting existing ones to use satellite data more directly.

\section{Acknowledgements}

The authors would like to acknowledge support from NASA Headquarters through funding for various projects related to the topic discussed in this paper. We also would like to thank Luke Ellison for preparing the fire map and Mariya Petrenko for help with data analysis and running the GOCART model. We would like to extend our appreciation to the science teams responsible for developing the various biomass-burning products referenced in this paper. Finally, we would like to thank Jeffrey Reid from the Naval Research Laboratory (NRL) and the anonymous reviewers, whose careful review of the original manuscript and valuable suggestions helped us to improve the quality of the paper. 


\section{References}

Adler, R.F., Huffman, G.J., Bolvin, D.T., Curtis, S., Nelkin, E.J., 2000. Tropical Rainfall Distributions Determined Using TRMM Combined with Other Satellite and Rain Gauge Information. J. Appl. Meteor. 39, 2007-2023.

Ahn, C., Torres, O., Bhartia, P.K., 2008. Comparison of Ozone Monitoring Instrument UV Aerosol Products with Aqua/Moderate Resolution Imaging Spectroradiometer and Multiangle Imaging Spectroradiometer observations in 2006. J. Geophys. Res. 113, D16S27, doi:10.1029/2007JD008832.

Al-Saadi, J., Szykman, J., Pierce, R.B., Kittaka, C., Neil, D., Chu, D.A., Remer, L., Gumley, L., Prins, E., Weinstock, L., MacDonald, C., Wayland, R., Dimmick, F., Fishman, J., 2005. Improving National Air Quality Forecasts with Satellite Aerosol Observations. Bull. Am. Met. Soc. 86, 1249-1261.

Amiridis, V., Giannakaki, E., Balis, D.S., Gerasopoulos, E., Pytharoulis, I., Zanis, P., Kazadzis, S., Melas, D., Zerefos, C., 2010. Smoke injection heights from agricultural burning in Eastern Europe as seen by CALIPSO. Atmos. Chem. Phys. 10, 1156711576, doi:10.5194/acp-10-11567-2010.

Andreae, M.O., "Biomass burning: Its history, use, and distribution and its impact on environmental quality and global climate," in Global Biomass Burning: Atmospheric, Climatic, and Biospheric Implications, edited by J. S. Levine, pp. 3 - 21, MIT Press, Cambridge, Mass., 1991.

Andreae, M.O., Merlet, P., 2001. Emission of trace gases and aerosols from biomass burning, Global Biogeochem. Cycles 15, 955- 966.

Andreae, M.O., Rosenfeld, D., Artaxo, P., Costa, A.A., Frank, G.P., Longo, K.M., SilvasDias, M.A.F., 2004. Smoking rain clouds over the Amazon, Science 303, 1337-1342.

Arino O. and J. M. Melinotte, 1995. Fire Index Atlas. Earth Observation Quarterly 50, 11-16.

Arya, S.P.S., Lape, J.F., Jr., 1990. A comparative study of the different criteria for the physical modeling of buoyant plume rise in a neutral atmosphere. Atmosph. Env. 24A, 289-295.

Barbosa, P.M., Stroppiana, D., Gregoire J.-M., 1999a. An assessment of vegetation fire in Africa (1981-1991): Burned areas, burned biomass, and atmospheric emissions. Global Biogeochem. Cycles 13(4), 933-950.

Barbosa, P.M., Stroppiana, D., Gregoire, J.-M., Pereira, J.M.C., 1999b. An Algorithm for Extracting Burned Areas from Time Series of AVHRR GAC Data Applied at a Continental Scale. Remote Sensing of Environment 69, 253-263.

Beer, R., Glavich, T.A., Rider, D.M., 2001. Tropospheric emission spectrometer for the Earth Observing System's Aura satellite. Appl. Opt. 40, 2356-2367.

Bhartia, P. K. (2007), Total ozone from backscattered ultraviolet measurements, in Observing Systems for Atmospheric Composition, edited by G. Visconti et al., pp. 4863, Springer, New York.

Boschetti, L., Roy, D.P., Justice, C.O., Giglio, L., 2010. Global assessment of the temporal reporting accuracy and precision of the MODIS burned area product. International Journal of Wildland fire 19, 705-709.

Bowman, D.M.J.S., Balch, J.K., Artaxo, P., Bond, W.J., Carlson, J.M., Cochrane, M.A., D’Antonio, C.M., DeFries, R.S., Doyle, J.C., Harrison, S.P., Johnston, F.H., Keeley, 
J.E., Krawchuk, M.A., Kull, C.A., Marston, J.B., Moritz, M.A., Prentice, I.C., Roos, C.I., Scott, A.C., Swetnam, T.W., van der Werf, G.R., Pyne, S.J., 2009. Fire in the Earth System. Science 324, 481-484, doi:10.1126/science.1163886.

Bowman, K.W., Worden, J., Steck, T., Worden, H.M., Clough, S., Rodgers, C., 2002. Capturing time and vertical variability of tropospheric ozone: A study using TES nadir retrievals. J. Geophys. Res. 107(D23), 4723, doi:10.1029/2002JD002150.

Brinksma, E.J., Bracher, A., Lolkema, D.E., Segers, A.J., Boyd, I.S., Bramstedt, K., Claude, H., Godin-Beekmann, S., Hansen, G., Kopp, G., Leblanc, T., McDermid, I.S., Meijer, Y.J., Nakane, H., Parrish, A., von Savigny, C., Stebel, K., Swart, D.P.J., Taha, G., Piters, A.J.M., 2006. Geophysical validation of SCIAMACHY Limb Ozone Profiles. Atmos. Chem. Phys. 6, 197-209, doi:10.5194/acp-6-197-2006.

Buchwitz, M., Schneising, O., Burrows, J.P., Bovensmann, H., Reuter, M., Notholt, J., 2007. First direct observation of the atmospheric $\mathrm{CO} 2$ year-to-year increase from space. Atmos. Chem. Phys. 7, 4249-4256, http://www.atmos-chemphys.net/7/4249/2007/.

Buchwitz, M., de Beek, R., Noël, S., Burrows, J.P., Bovensmann, H., Schneising, O., Khlystova, I., Bruns, M., Bremer, H., Bergamaschi, P., Körner, S., Heimann, M., 2006. Atmospheric carbon gases retrieved from SCIAMACHY by WFM-DOAS: version $0.5 \mathrm{CO}$ and $\mathrm{CH} 4$ and impact of calibration improvements on $\mathrm{CO} 2$ retrieval. Atmos. Chem. Phys. 6, 2727-2751, http://www.atmos-chem-phys.net/6/2727/2006/.

Buchwitz, M., de Beek, R., Burrows, J.P., Bovensmann, H., Warneke, T., Notholt, J., Meirink, J.F., Goede, A.P.H., Bergamaschi, P., Körner, S., Heimann, M., Schulz, A., 2005a. Atmospheric methane and carbon dioxide from SCIAMACHY satellite data: Initial comparison with chemistry and transport models. Atmos. Chem. Phys. 5, 941962, http://www.atmos-chem-phys.net/5/941/2005/.

Buchwitz, M., de Beek, R., Noël, S., Burrows, J. P., Bovensmann, H., Bremer, H., Bergamaschi, P., Körner, S., Heimann, M., 2005b. Carbon monoxide, methane, and carbon dioxide retrieved from SCIAMACHY by WFM-DOAS: year 2003 initial data set. Atmos. Chem. Phys. 5, 3313-3329, http://www.atmos-chemphys.net/5/3313/2005/.

Burgan, R.E., Klaver, R.W., Klaver, J.M., 1998. Fuel models and fire potential from satellite and surface observations. International Journal of Wildland Fire 8, 159-170.

Burling, I.R., Yokelson, R.J., Akagi, S.K., Urbanski, S.P., Wold, C.E., Griffith, D.W.T., Johnson, T.J., Reardon, J., Weise, D.R., 2011. Airborne and ground-based measurements of the trace gases and particles emitted by prescribed fires in the United States. Atmos. Chem. Phys. Disc. 11, 18677-18727. doi:10.5194/acpd-1118677-2011.

Butz, A. et al., 2011. Toward accurate $\mathrm{CO}_{2}$ and $\mathrm{CH}_{4}$ observations from GOSAT, Geophys. Res. Lett., 38, L03801, doi:10.1029/2010GL045896.

Byun, D.W., Schere, K.L., 2006. Review of the Governing Equations, Computational Algorithms, and Other Components of the Models-3 Community Multiscale Air Quality (CMAQ) Modeling System. Applied Mechanics Reviews. American Society of Mechanical Engineers, Fairfield, NJ. 59(2), 51-77.

Cahill, C.F., Cahill, T.A., Perry, K.D., 2008. The Size- and Time-Resolved Composition of Aerosols from a Sub-Boreal Forest Prescribed Burn. Atmos. Environ. 42, 75537559, doi: 10.1016/j.atmosenv.04.034. 
Cahoon Jr., D.R., Stocks, B.J., Levine, J.S., Cofer III, W.R., O’Neill, K.P., 1992a. Seasonal distribution of African savanna fires. Nature 359(29), 812-815.

Cahoon Jr., D.R., Stocks, B.J., Levine, J.S., Cofer III, W.R., Chung, C.C., 1992b. Evaluation of a technique for satellite-derived estimation of biomass burning. J. Geophys. Res. 97(D4), 3805-3814.

Cahoon, D., Jr., Stocks, B.J., Levine, J.S., Cofer III, W.R., Pierson, J., 1994. Satellite analysis of the severe 1987 forest fires in northern China and southeastern Siberia. J. Geophys. Res. 99(D9), 18627-18638.

Calle, A., Casanova, J.-L., Gonaz-Allonso, F. , 2009. Impact of point spread function of MSG-SEVIRI on active fire detection. International Journal of Remote Sensing 30, 4567-4579.

Cammas, J.-P., Brioude, J., Chaboureau, J.-P., Duron, J., Mari, C., Mascart, P., Nédélec, P., Smit, H., Pätz, H.-W., Volz-Thomas, A., Stohl, A., and Fromm, M., 2009. Injection in the lower stratosphere of biomass fire emissions followed by long-range transport: a MOZAIC case study. Atmos. Chem. Phys. 9, 5829-5846, doi:10.5194/acp-9-5829-2009.

Carmona-Moreno, C., Belward, A., Malingreau, J.P., Hartley, A., Garcia-Algere, M., Antonovskiy, M., Buchshtaber, V., Pivovarov, V., 2005 Characterizing interannual variations in global fire calendar using data from Earth observing satellites. Glob. Chang. Biol. 11(9), 1537-1555.

Cattrall, C., Reagan, J., Thome, K., Dubovik, O., 2005. Variability of aerosol and spectral lidar and backscatter and extinction ratios of key aerosol types derived from selected Aerosol Robotic Network locations. J. Geophys. Res. 110, D10S11, doi:10.1029/2004JD005124.

Chahine, M.T., Chen, L., Dimotakis, P., Jiang, X., Li, Q., Olsen, E. T., Pagano, T., Randerson, J., Yung, Y.L., 2008. Satellite remote sounding of mid-tropospheric CO2. Geophys. Res. Lett. 35, L17807, doi:10.1029/2008GL035022.

Chahine, M.T., et al., 2006. AIRS: Improving weather forecasting and providing new data on greenhouse gases. Bull. Am. Meteorol. Soc. 87, 911 -926.

Chen, Y., Li, Q., Randerson, J.T., Lyons, E.A., Kahn, R.A., Nelson, D.L., Diner, D.J., 2009. The sensitivity of $\mathrm{CO}$ and aerosol transport to the temporal and vertical distribution of North American boreal fire emissions. Atmos. Chem. Phys. 9, 65596580, doi:10.5194/acp-9-6559-2009.

Chen W.-T., Kahn R.A., Nelson D.L., Yau K., Seinfeld, J., 2008. Sensitivity of multiangle imaging to optical and microphysical properties of biomass burning aerosols. J Geophys Res 113:D10203, doi:10.1029/2007JD009414.

Chin, M., Ginoux, P., Kinne, S., Torres, O., Holben, B.N., Duncan, B.N., Martin, R.V., Logan, J.A., Higurashi, A., Nakajima, T., 2002. Tropospheric aerosol optical thickness from the GOCART model and comparisons with satellite and sun photometer measurements. J. Atmos. Sci., 59, 461-483.

Chopping, M., Moisen, G., Su, L., Laliberte, A., Rango, A., Martonchik, J.V., Peters, D.P.C., 2008. Large area mapping of southwestern forest crown cover, canopy height, and biomass using the NASA Multiangle Imaging Spectro-Radiometer. Remote Sensing of Environment 112, 2051-2063.

Chung, Y.S., Le, H.V., 1984. Detection of forest-fire smoke plumes by satellite imagery. Atmos. Environ. 18, 2143-2151. 
Clements C.B., 2007. FIREFLUX - observing wildland grass fire dynamics. Bulletin of the American Meteorological Society 88, 1369-1382.

Cochrane, M.A., 2003. Fire science for rainforests. Nature, London 421:913-919.

Cofer, III, W.R., Levine, J.S., Sebacher, D.I., Winstead, E.L., Riggan, P.J., Brass, J.A., Ambrosia, V.G., 1988. Particulate Emissions from a Mid-Latitude Prescribed Chaparral Fire. Journal of Geophysical Research 93(D2), 5207-5212.

Cogan, J.L., 1985. Monte Carlo simulation of buoyant dispersion. Atmosph. Env. 19, 867-878.

Colarco, P.R., Schoeberl, M.R. Doddridge, B.G., Marufu, L.T., Torres, O., Welton, E.J., 2004. Transport of smoke from Canadian forest fires to the surface near Washington, D.C.: Injection height, entrainment, and optical properties. J. Geophys. Res. 109, D06203, doi:10.1029/2003JD004248.

Crutzen, P.J., Andreae, M.O., 1990. Biomass burning in the tropics: Impact on atmospheric chemistry and biogeochemical cycles. Science 250, 1669-1678.

Csiszar, I.A., Morisette, J.T., Giglio, L., 2006. Validation of active fire detection from moderate-resolution satellite sensors: The MODIS example in northern Eurasia. IEEE Transactions and Geosciences and Remote Sensing 44, 1757-1764.

Csiszar, I., Schroeder, W., 2008. Short-term observations of the temporal development of active fire from consecutive same-day ETM+ and ASTER imagery in the Amazon: Implications for active fire product validation. IEEE Journal of Selected Topics in Applied Earth Observations and Remote Sensing. 1(4), 248-253.

Damoah, R., Spichtinger, N., Forster, C., James, P., Mattis, I., Wandinger, U., Beirle, S., Wagner, T., and Stohl, A., 2004. Around the world in 17 days - hemispheric-scale transport of forest fire smoke from Russia in May 2003. Atmos. Chem. Phys. 4, 13111321, doi:10.5194/acp-4-1311-2004.

Davies, D.K., Ilavajhala, S. et al., 2009. Fire Information for Resource Management System: Archiving and Distributing MODIS Active Fire Data. IEEE Transactions on Geoscience and Remote Sensing 47(1), 72-79.

De Santis, A., Asner, G.P., Vaughan, P.J., Knapp, D.E., 2010. Mapping burn severity and burning efficiency in California using simulation models and Landsat imagery. Remote Sensing of Environment 114, 1535-1545.

Deeter, M. N., et al., 2003. Operational carbon monoxide retrieval algorithm and selected results for the MOPITT instrument. J. Geophys. Res. 108(D14), 4399, doi:10.1029/2002JD003186.

Dey, S., Di Girolamo, L., 2010. A climatology of aerosol optical and microphysical properties over the Indian subcontinent from 9 years (2000-2008) of Multiangle Imaging Spectroradiometer (MISR) data. J. Geophys. Res., 115, D15204, doi:10.1029/2009JD013395.

Dozier, J., 1981. A method for satellite identification of surface temperature fields of subpixel resolution. Remote Sens. Environ. 11, 221-229.

Dubovik, O., Lapyonok, T., Kaufman, Y.J., Chin, M., Ginoux, P., Kahn, R. A., Sinyuk, A., 2008. Retrieving global aerosol sources from satellites using inverse modeling. Atmos. Chem. Phys. 8(2), $209-250$.

Dufour, G., Wittrock, F., Camredon, M., Beekmann, M., Richter, A., Aumont, B., Burrows, J.P., 2009. SCIAMACHY formaldehyde observations: constraint for 
isoprene emission estimates over Europe? Atmos. Chem. Phys. 9, 1647-1664, doi:10.5194/acp-9-1647-2009.

Duncan, B.N., Martin, R.V., Staudt, A.C., Yevich, R., Logan, J.A., 2003. Interannual and seasonal variability of biomass burning emissions constrained by satellite observations. J. Geophys. Res., 108(D2), 4100, doi:10.1029/2002JD002378.

Eckmann, T.C., Roberts, D.A., Still, C.J., 2009. Estimating subpixel fire sizes and temperatures from ASTER using multiple endmember spectral mixture analysis. International Journal of Remote Sensing 30(22), 5851-5864.

Edwards, D.P., et al., 2006. Satellite-observed pollution from Southern Hemisphere biomass burning. J. Geophys. Res. 111, D14312, doi:10.1029/2005JD006655.

Edwards, D.P., et al., 2004. Observations of carbon monoxide and aerosols from the Terra satellite: Northern Hemisphere variability. J. Geophys. Res. 109, D24202, doi:10.1029/2004JD004727.

Edwards, D.P., et al., 2003. Tropospheric ozone over the tropical Atlantic: A satellite perspective. J. Geophys. Res. 108(D8), 4237, doi:10.1029/2002JD002927.

EPA, 2005. Clean Air Interstate Rule-Basic Information. Washington, DC:U.S. Environmental Protection Agency. Available: http://www.epa.gov/interstateairquality/basic.html.

Epting J., Verbyla D., Sorbel B., 2005. Evaluation of remotely sensed indices for assessing burn severity in interior Alaska using Landsat TM and ETM+. Remote Sens. Environ. 96(3-4), 328-339.

Eva, H., Flasse, S., 1996. Contextual and multiple-threshold algorithms for regional active fire detection with AVHRR data. Remote Sensing Reviews 14, 333-351.

Ferrare, R.A., Fraser, R.S., Kaufman, Y.J., 1990. Satellite remote sensing of large-scale air pollution-Measurements of forest fires smoke. J. Geophys. Res. 95, 9911-9925.

Flasse, S.P., Ceccato, P., 1996. A contextual algorithm for AVHRR fire detection. International Journal of Remote Sensing, 17, 419-424.

Flannigan, M.D., Wotton, B.M., 1991. Lightning-ignited forest-fires in northwestern Ontario. Canadian Journal of Forest Research-Revue Canadienne De Recherche Forestiere 21, 277-287.

Fleming, Z.L., Monks, P.S., Manning, A.J., 2012. Review: Untangling the influence of air-mass history in interpreting observed atmospheric composition. Atmospheric Research 104-105, 1-39

Forster, P., Ramaswamy, V., Artaxo, P., Berntsen, T., Betts, R., Fahey, D.W., Haywood, J., Lean, J., Lowe, D.C., Myhre, G., Nganga, J., Prinn, R., Raga, G.M.S., Van Dorland, R., 2007. Changes in Atmospheric Constituents and in Radiative Forcing; Cambridge: New York.

Frankenberg, C., Meirink, J.F., Bergamaschi, P., Goede, A.P.H., Heimann, M., Ko r̈ner, S., Platt, U., van Weele, M., Wagner, T., 2006. Satellite chartography of atmospheric methane from SCIAMACHY on board ENVISAT: Analysis of the years 2003 and 2004. J. Geophys. Res. 111, D07303, doi:10.1029/2005JD006235.

Frankenberg, C., Meirink, J.F., van Weele, M., Platt, U., and Wagner, T., 2005a. Assessing methane emissions from global spaceborne observations. Science 308, $1010-1014$. 
Frankenberg, C., Platt, U., Wagner, T., 2005b. Retrieval of CO from SCIAMACHY onboard ENVISAT: Detection of strongly polluted areas and seasonal patterns in global CO abundances. Atmos. Chem. Phys. 5, $1639-1644$.

Fraser, R.H., Li, Z., Cihlar, J., 2000. Hotspot and NDVI differencing synergy (HANDS): A new technique for burned area mapping over boreal forest. Remote Sensing of Environment, 74, 362-376.

Fraser, R.H., Hall, R.J., Landry, R., Lynham, T., Lee, B., Li, Z., 2004. Validation and calibration of Canada-wide coarse-resolution satellite burned area maps. Photogrammetric Engineering \& Remote Sensing 70, 451- 460.

Freeborn, P.H., Wooster, M.J., Hao, W.M., Ryan, C.A., Nordgren, B.L., Baker, S.P., Ichoku, C., 2008. Relationships between energy release, fuel mass loss, and trace gas and aerosol emissions during laboratory biomass fires. J. Geophys. Res. 113, D01301, doi:10.1029/2007JD008679.

Freeborn, P.H, Wooster, M.J., Roberts, G., Malamud, B.D., \& Xu, W., 2009. Development of a virtual active fire product for Africa through a synthesis of geostationary and polar orbiting satellite data. Remote Sensing of Environment 113(8), 1700-1711 August 2009.

Freitas, S., Longo, K.M., et al., 2005. Monitoring the transport of biomass burning emissions in South America. Environmental Fluid Mechanics 5, 135-167.

Freitas, S.R., Longo, K.M., Andreae, M.O., 2006. Impact of including the plume rise of vegetation fires in numerical simulations of associated atmospheric pollutants. Geophys. Res. Lett. 33, L17808, doi:10.1029/2006GL026608.

Freitas, S., Longo, K.M., Chatfield, R., Latham, D., Silva Dias, M.A., Andreae, M.O., Prins, E., Santos, J.C., Gielow, R., Carvalho, Jr., J.A., 2007. Including the sub-grid scale plume rise of vegetation fires in low resolution atmospheric transport models. Atmos. Chem. Phys. 7, 3385-3398.

French N.H.F., Kasischke E.S., Hall R.J., Murphy K.A., Verbyla D.L., Hoy E.E., Allen J.L., 2008. Using Landsat data to assess fire and burn severity in the North American boreal forest region: an overview and summary of results. Int. J. Wildland Fire 17(4): 443-462.

Gatebe, C.K., Varnai, T., Poudyal, R., Ichoku, C., King, M.D., 2012. Taking the pulse of pyrocumulus clouds, Atmospheric Environment. doi:10.1016/j.atmosenv.2012.01.045

George, M., Clerbaux, C., Hurtmans, D., et al., 2009. Carbon monoxide distributions from the IASI/METOP mission: evaluation with other spaceborne remote sensors, Atmos. Chem. Phys., 9, 8317-8330.

Giglio, L., 2007. Characterization of the tropical diurnal cycle using VIRS and MODIS observations. Remote Sensing of Environment 108, 407-421.

Giglio, L., Csiszar, I., Restás, A., Morisette, J., Schroeder, W., Morton, D., Justice, C., 2008. Active fire detection and characterization with the Advanced Spaceborne Thermal Emission and Reflection Radiometer (ASTER). Remote Sensing of Environment 112, 3055-3063.

Giglio, L., Descloitres, J., Justice, C., Kaufman, Y., 2003a. An enhanced contextual fire detection algorithm for MODIS. Remote Sensing of Environment 87, 273- 282.

Giglio, L., Kendall, J.D., 2001. Application of the Dozier retrieval to wildfire characterization: A sensitivity analysis. Remote Sensing of Environment 77, 34-49. 
Giglio, L., Kendall, J.D., Mack, R., 2003b. A multi-year active fire dataset for the tropics derived from the TRMM VIRS. Int. J. Remote Sensing 24(22), 4505-4525.

Giglio, L., Kendall, J.D., Tucker, C.J., 2000. Remote sensing of fires with the TRMM VIRS. International Journal of Remote Sensing 21, 203-207.

Giglio, L., Kendall, J.D., Justice, C.O., 1999. Evaluation of global fire detection algorithms using simulated AVHRR infrared data. Int. J. Remote Sensing 20, 19471985.

Giglio, L., van der Werf, G.R., Randerson, J.T., Collatz, G.J., Kasibhatla, P., 2006. Global estimation of burned area using MODIS active fire observations, Atmos. Chem. Phys., 6, 957-974, doi:10.5194/acp-6-957-2006.

Grégoire, J.-M., Tansey, K., Silva, J.M.N., 2003. The GBA2000 initiative: Developing a global burned area database from SPOT-VEGETATION imagery. Int. J. Remote Sens. 24(6), $1369-1376$.

Grell G.A., Peckham, S.E., Schmitz, R., McKeen, S.A., Frost, G., Skamarock, W.C., Eder, B., 2005. Fully coupled 'online' chemistry within the WRF model. Atmos. Environ., 39, 6957-6976.

Haines, D.A., 1988. A lower atmosphere severity index for wildland fire. National Weather Digest, 23-27

Hansen, J., Nazarenko, L., 2004. Soot climate forcing via snow and ice albedos. Proc. Natl Acad. Sci. USA 101, 423-428.

Hao, W.M., Liu, M.-H., 1994. Spatial and temporal distribution of tropical biomass burning. Global Biogeochem. Cycles, 8, 495-503.

Heikes, L., Ransohoff, L., Small, R., 1990. Numerical simulation of small area fires. Atmos. Environ. 24A, 297-307.

Henderson S.B., Burkholder, B., Jackson, P.L., Brauer, M., Ichoku, C., 2008. Use of MODIS products to simplify and evaluate a forest fire plume dispersion model for PM10 exposure assessment. Atmos. Env. 42, 8524-8532.

Henze, D.K., Hakami, A., Seinfeld, J. H., 2007. Development of the adjoint of GEOSChem. Atmos. Chem. Phys. 7, 2413-2433.

Henze, D.K., Seinfeld, J.H., Shindell, D.T., 2009. Inverse modeling and mapping US air quality influences of inorganic PM2.5 precursor emissions using the adjoint of GEOS-Chem. Atmos. Chem. Phys. 9, 5877-5903.

Herzog, M., Oberhuber, J.M., Graf, H.-F., 2003. A prognostic turbulence scheme for the nonhydrostatic plume model ATHAM. J. Atmosph. Sci. 60, 2783-2796.

Hodzic, A., Madronich, S., Bohn, B., Massie, S., Menut, L., and Wiedinmyer, C., 2007. Wildfire particulate matter in Europe during summer 2003: meso-scale modeling of smoke emissions, transport and radiative effects. Atmos. Chem. Phys., 7, 4043-4064, doi:10.5194/acp-7-4043-2007.

Hoff, R. M., Christopher, S. A., 2009. Remote Sensing of Particulate Pollution from Space: Have We Reached the Promised Land? J. Air \& Waste Manage. Assoc. 59, 645-675 DOI:10.3155/1047-3289.59.6.645.

Hoelzemann, J. J., Schultz, M. G., Brasseur, G. P., Granier, C., Simon, M., 2004. Global wildland fire emission model (GWEM): Evaluating the use of global area burnt satellite data. J. Geophys. Res. 109, D14S04. DOI: 10.1029/2003JD003666. 
Hsu, N. C., Herman, J. R., Gleason, J. F., Torres, O., Seftor, C. J., 1999. Satellite detection of smoke aerosols over a snow/ice surface by TOMS, Geophys. Res. Lett. 26, 1165-1168.

Hsu, N.C., Herman, J.R., Bhartia, P.K., Seftor, C.J., Torres, O., Thompson, A.M., Gleason, J.F., Eck, T.F., Holben, B. N., 1996. Detection of biomass burning smoke from TOMS measurements. Geophys. Res. Lett. 23(7), 745-748, doi:10.1029/96GL00455.

Hyer, E.J., Reid, J.S., 2009. Baseline uncertainties in biomass burning emission models resulting from spatial error in satellite active fire location data. Geophys. Res. Lett. 36, L05802, doi:10.1029/2008GL036767.

Ichoku, C., Giglio, L., Wooster, M.J., Remer, L.A., 2008a. Global characterization of biomass-burning patterns using satellite measurements of Fire Radiative Energy. Remote Sens. Environ. 112, 2950-2962.

Ichoku, C., Kaufman, Y.J., 2005. A method to derive smoke emission rates from MODIS fire radiative energy measurements. IEEE Trans. Geosci. Rem. Sensing 43(11), 26362649.

Ichoku, C., Kaufman, Y.J., Giglio, L., Li, Z., Fraser, R.H., Jin, J.-Z., Park, W.M., 2003a. Comparative analysis of daytime fire detection algorithms, using AVHRR data for the 1995 fire season in Canada: Perspective for MODIS. International Journal of Remote Sensing 24(8), 1669-1690.

Ichoku, C., Martins, J.V., Kaufman, Y.J., Wooster, M.J., Freeborn, P.H., Hao, W.M., Baker, S., Ryan, C.A., Nordgren, B.L., 2008b. Laboratory investigation of fire radiative energy and smoke aerosol emissions. J. Geophys. Res. 113, D14S09, doi:10.1029/2007JD009659.

Ichoku, C., Remer, L.A., Kaufman, Y.J., Levy, R., Chu, D.A., Tanre, D., Holben, B.N., 2003b. MODIS Observation of Aerosols and Estimation of Aerosol Radiative Forcing Over Southern Africa during SAFARI 2000. J. Geophys. Res., 108(D13), 8499, doi: 10.1029/2002JD002366.

Ignatov, A., Sapper, J., Cox, S., Laszlo, I., Nalli, N.R., Kidwell, K.B., 2004. Operational aerosol observations (AEROBS) from AVHRR/3 on board NOAA-KLM satellites. J. Atmos. Oceanic Technol. 21(1), 3-26.

Ito, A., Penner, J. E., 2004. Global estimates of biomass burning emissions based on satellite imagery for the year 2000. J. Geophys. Res. 109(D14S05), doi:10.1029/2003JD004423.

Jonquières, I., Marenco, A., Maalej, A., Rohrer, F., 1998. Study of ozone formation and transatlantic transport from biomass burning emissions over West Africa during the airborne Tropospheric Ozone Campaigns TROPOZ I and TROPOZ II. J. Geophys. Res. 103(D15), 19,059-19,073, doi:10.1029/98JD00819.

Jordan N., Ichoku, C., Hoff, R., 2008. Estimating Smoke Emissions Over The U.S. Southern Great Plains Using MODIS Fire Radiative Power and Aerosol Observations. Atmos. Env. 42, 2007-2022.

Justice, C., Giglio, L., Korontzi, S., Owens, J., Morisette, J., Roy, D., Descloitres, J., Alleaume, S., Petitcolin, F., Kaufman, Y., 2002. The MODIS fire products. Remote Sensing of Environment 83, 244-262.

Justice, C.O., Kendall, J.D., Dowty, P.R., Scholes, R.J., 1996. Satellite remote sensing of fires during the SAFARI campaign using NOAA AVHRR data. Journal of Geophysical Research 101(D23):23851-23863. 
Justice, C.O., Malingreau, J.-P., Setzer, A. W., 1993. Satellite remote sensing of fires: Potential and limitations. In P. J. Crutzen and J. G. Goldammer, editors, Fire in the Environment, pages 77-88. Wiley, New York.

Kaiser, J.W., Heil, A., Andreae, M.O., Benedetti, A., Chubarova, N., Jones, L., Morcrette, J.-J., Razinger, M., Schultz, M.G., Suttie, M., and van der Werf, G.R., 2012. Biomass burning emissions estimated with a global fire assimilation system based on observations of fire radiative power. Biogeosciences 9, 527-554, doi:10.5194/bg-9-527-2012.

Kahn, R.A., Chen, Y., Nelson, D.L., Leung, F.-Y., Li, Q., Diner, D.J., Logan, J.A., 2008. Wildfire smoke injection heights: Two perspectives from space. Geophys. Res. Lett., 35, L04809, doi:10.1029/2007GL032165.

Kahn, R.A., Li, W.-H., Moroney, C., Diner, D.J., Martonchik, J.V., Fishbein, E., 2007. Aerosol source plume physical characteristics from space-based multiangle imaging. J. Geophys. Res. 112, D11205, doi:10.1029/2006JD007647.

Kahn, R.A., Nelson, D.L., Garay, M., Levy, R.C., Bull, M.A., Martonchik, J.V., Diner, D.J., Paradise, S.R., Wu, D.L., Hansen, E.G., Remer, L. A., 2009. MISR Aerosol product attributes, and statistical comparisons with MODIS. IEEE Trans. Geosci. Rem. Sens. 47(12), 4095-4114.

Kahn, R.A., Gaitley, B.J., Garay, M.J., Diner, D.J., Eck, T., Smirnov, A., Holben, B.N., 2010. Multiangle Imaging SpectroRadiometer global aerosol product assessment by comparison with the Aerosol Robotic Network. J. Geophys. Res. 115, D23209, doi: 10.1029/2010JD014601.

Kalashnikova, O.V., Kahn, R.A., 2008. Mineral dust plume evolution over the Atlantic from MISR and MODIS aerosol retrievals. J. Geophys. Res. 113, D24204, doi:10.1029/2008JD010083.

Kasischke, E.S., Penner, J.E., 2004. Improving global estimates of atmospheric emissions from biomass burning. J. Geophys. Res. 109(D14S01), doi:10.1029/2004JD004972.

Kaufman, Y.J., Fraser, R.S., 1997. The effect of smoke particles on clouds and climate forcing. Science 277, 1636-1639.

Kaufman, Y.J., Ichoku, C., Giglio, L., Korontzi, S., Chu, D.A., Hao, W.M., Li, R.-R., Justice, C.O., 2003. Fires and smoke observed from the Earth Observing System MODIS instrument - products, validation, and operational use. International Journal of Remote Sensing 24(8), 1765-1781.

Kaufman, Y.J., Remer, L.A., Ottmar, R.D., Ward, D.E., Li, R.-R., Kleidman, R., Fraser, R.S., Flynn, L., McDougal, D., Shelton, G., 1996. Relationship between remotely sensed fire intensity and rate of emission of smoke: SCAR-C experiment. In Global Biomass Burning, edited by J. Levin (Cambridge, MA: The MIT press), pp. 685-696.

Kaufman, Y., Justice, C., Flynn, L., Kendall, J., Prins, E., Giglio, L., Ward, D., Menzel, W., Setzer, A., 1998a. Potential global fire monitoring from EOS-MODIS. Journal of Geophysical Research-Atmospheres 103(D24), 32,215- 32,238.

Kaufman, Y.J., et al., 1998b. Smoke, Clouds, and Radiation-Brazil (SCAR-B) experiment. J. Geophys. Res. 103(D24), 31,783-31,808, doi:10.1029/98JD02281.

Kaufman, Y. J., Boucher, O., Tanre', D., Chin, M., Remer, L.A., Takemura, T., 2005. Aerosol anthropogenic component estimated from satellite data. Geophys. Res. Lett. 32, L17804, doi:10.1029/2005GL023125. 
Kaufman, Y. J., Tucker, C. J., Fung, I., 1990. Remote sensing of biomass burning in the tropics. Journal of Geophysical Research 95, 9927-9939.

Kennedy, P.J., Belward, A.S., Gregoire, J.-M., 1994. An improved approach to fire monitoring in West Africa using AVHRR data. International Journal of Remote Sensing 15, 2235-2225.

Kopacz, M., Jacob, D., Henze, D.K., Heald, C.L., Streets, D.G., and Zhang, Q., 2009. A comparison of analytical and adjoint Bayesian inversion methods for constraining Asian sources of CO using satellite (MOPITT) measurements of CO columns. J. Geophys. Res.-Atmos., 114, D04305, doi:10.1029/2007JD009264.

Koren H.S., 1995. Associations between criteria air pollutants and asthma. Environ Health Perspect. 103(suppl 6), 235-242.

Koren, I., Kaufman, Y.J., Remer, L.A., and Martins, J.V., 2004. Measurements of the effect of smoke aerosol on inhibition of cloud formation, Science 303, 1342-1345.

Korontzi, S., Roy, D.P., Justice, C.O., Ward, D.E., 2004. Modeling and sensitivity analysis of fire emissions in southern Africa during SAFARI 2000. Remote Sens. Environ. 92, 255-275.

Kremens, R.L., Smith, A.M.S., Dickinson, M.B., 2010. Fire metrology: current and future directions in physics-based measurements. Fire Ecology 6, 13-35.

Labonne, M., Bre'on, F.-M., Chevallier, F., 2007. Injection height of biomass burning aerosols as seen from a spaceborne lidar. Geophys. Res. Lett. 34, L11806, doi:10.1029/2007GL029311.

Lacaux, J.-P., Brocard, D., Lacaux, C., Delmas, R., Brou, A., Yobou, V., Koffi, M., 1994. Traditional charcoal making: an important source of atmospheric pollution in the African Tropics. Atmospheric Research 35, 71-76.

Langaas, S.A., 1993. Parametrised bispectral model for savanna fire detection using AVHRR night images. International Journal of Remote Sensing 14, 2245-2262.

Lavoue, D., Liousse, C., Cachier, H., Stocks, B.J., Goldammer, J.G., 2000. Modeling of carbonaceous particles emitted by boreal and temperate wildfires at northern latitudes. J. Geophys. Res.-Atmos., 105, 26871-26890.

Lee, T.F., Tag, P.M., 2007. Improved detection of hotspots using AVHRR $3.7 \mu \mathrm{m}$ channel. Bulletin of the American Meteorological Society, 71:1722-1730, 1990.

Leung, F.-Y., J.A. Logan, R. Park, E. Hyer, E. Kasischke, D. Streets, and L. Yuganov, 2007. Impacts of biomass burning in the boreal forests on tropospheric chemistry and the sensitivity of model results to injection height. J. Geophys. Res. 112, D10313, doi:10.1029/2006JD008132.

Levy, R.C., Remer, L.A., Kleidman, R.G., Mattoo, S., Ichoku, C., Kahn, R., and Eck, T.F., 2010. Global evaluation of the Collection 5 MODIS dark-target aerosol products over land. Atmos. Chem. Phys. 10, 10399-10420, doi:10.5194/acp-10-10399-2010.

Li R.-R., Kaufman, Y.J., Hao, W.-M., Salmon, J.M., Gao, B.-C., 2004. A Technique for Detecting Burn Scars Using MODIS Data. IEEE Trans. on Geoscience \& Remote Sensing 6(42), 1300-1308.

Li, Z., Fraser, R., Jin, J., Abuelgasim, A.A., Csiszar, I., Gong, P., Pu, R., Hao, W.M., 2003. Evaluation of algorithms for fire detection and mapping across North America from satellite. J. Geophys. Res. 108(D2), 4076, doi:10.1029/2001JD001377.

Li, Z., Kaufman, Y.J. Ichoku, C., Fraser, R., Trishchenko, A., Giglio, L., et al., 2001. A review of AVHRR-based active fire detection algorithms: principles, limitation, and 
recommendations. In F. J. Ahern, J. G.Goldammer, \& C.O. Justice (Eds.), Global and Regional Vegetation Monitoring from Space: Planning a Coordinated International Effort (pp. 199-225). The Hague: SPB Academic Publishing.

Liousse, B., Guillaume, J.M., Gr'egoire, M., Mallet, C., et al., 2010. Updated African biomass burning emission inventories in the framework of the AMMA-IDAF program, with an evaluation of combustion aerosols. Atmospheric Chemistry and Physics 10, 7347-7382.

Liu, X., Chance, K., Sioris, C.E., Kurosu, T.P., Spurr, R.J.D., Martin, R.V., Fu, M., Logan, J.A., Jacob, D.J., Palmer, P.I., Newchurch, M.J., Megretskaia, I., Chatfield, R., 2006. First directly-retrieved global distribution of tropospheric column ozone: comparison with the GOES-CHEM model. J. Geophys. Res. 111(D2), D02308, 10.1029/2005JD006564.

Liu, Y., Koutrakis, P., Kahn, R., 2007a. Estimating Fine Particulate Matter Component Concentrations and Size Distributions Using Satellite- Retrieved Fractional Aerosol Optical Depth. Part 1: Method Development. J. Air \& Waste Manage. Assoc. 57, 1351-1359; doi: 10.3155/1047-3289.57.11.1351.

Liu Y., Koutrakis P., Kahn R.A., Turquety S., Yantosca R.M., 2007b. Estimating PM2.5 component concentrations and size distributions using satellite-retrieved fractional aerosol optical depth: Part 2 - a case study. J. Air Waste Manage. Assoc. 57, 1360-9.

Longo, K.M., Freitas, S.R., Andreae, M.O., Setzer, A., Prins, E., and Artaxo, P., 2010. The Coupled Aerosol and Tracer Transport model to the Brazilian developments on the Regional Atmospheric Modeling System (CATT-BRAMS) - Part 2: Model sensitivity to the biomass burning inventories. Atmos. Chem. Phys. 10, 5785-5795, doi:10.5194/acp-10-5785-2010.

Lopez, J. P., Luo, M., Christensen, L. E., Loewenstein, M., Jost, H., Webster, C.R., Osterman, G., 2008. TES carbon monoxide validation during two AVE campaigns using the Argus and ALIAS instruments on NASA's WB-57F. J. Geophys. Res. 113, D16S47, doi:10.1029/2007JD008811.

Luckman, A., Baker, J., Honzak, M., Lucas, R., 1998. Tropical forest biomass density estimation using JERS-1 SAR: seasonal variation, confidence limits, and application to image mosaics. Remote Sensing of Environment 63, pp. 126-139.

Luderer, G., Trentmann, J., Winterrath, T., Textor, C., Herzog, M., Graf, H.F., Andreae, M.O., 2006. Modeling of biomass smoke injection into the lower stratosphere by a large forest fire (Part II): sensitivity studies. Atmos. Chem. Phys. 6, 5261-5277, doi:10.5194/acp-6-5261-2006.

Mack, M.C., Bret-Harte, M.S., Hollingsworth, T.N., Jandt, R.R., Schuur, E.A.G., Shaver, G.R., Verbyla, D.L., 2011. Carbon loss from an unprecedented Arctic tundra wildfire, Nature 475, 489-492.

Malingreau J.-P., 1990. The contribution of remote sensing to the global monitoring of fires in tropical and subtropical ecosystems. In J. G. Goldammer, editor, Fire in the Tropical Biota: Ecosystem Processes and Global Challenges, pages 337-370. Springer-Verlag, Berlin.

Malingreau, J.P., Stephens, G., Fellows, L., 1985. Remote sensing of forest fires: Kalimantan and North Borneo in 1982-3. Ambio 14(6), 314-315.

Martin, R.V., Parrish, D.D., Ryerson, T.B., Nicks, Jr., D.K., Chance, K., Kurosu, T.P., Jacob, D.J., Sturges, E.D., Fried, A., Wert, B.P., 2004. Evaluation of GOME satellite 
measurements of tropospheric $\mathrm{NO} 2$ and $\mathrm{HCHO}$ using regional data from aircraft campaigns in the southeastern United States. J. Geophys. Res. 109, D24307, doi:10.1029/2004JD004869.

Martin, R.V., Jacob, D.J., Chance, K., Kurosu, T.P., Palmer, P.I., Evans, M.J., 2003. Global inventory of nitrogen oxide emissions constrained by space-based observations of NO2 columns. J. Geophys. Res. 108(D17), 4537, doi:10.1029/2003JD003453.

Matson, M., Dozier, J., 1981. Identification of subresolution high temperature sources using a thermal IR sensor. Photogrammetric Engineering and Remote Sensing 47, $1311-1318$.

Matson, M. Holben B. N, 1987. Satellite detection of tropical burning in Brazil. International Journal of Remote Sensing 8, 509-516.

McMillan, W.W., Barnet, C., Strow, L., Chahine, M., Warner, J., McCourt, M., Novelli, P., Korontzi, S., Maddy, E., Datta, S., 2005. Daily global maps of carbon monoxide from NASA's Atmospheric Infrared Sounder. Geophys. Res. Lett. 32, L11801, doi:10.1029/2004GL021821.

McMillan, W.W., et al., 2008. AIRS views transport from 12 to 22 July 2004 Alaskan/Canadian fires: Correlation of AIRS CO and MODIS AOD with forward trajectories and comparison of AIRS CO retrievals with DC-8 in situ measurements during INTEX-A/ICARTT. J. Geophys. Res. 113, D20301, doi:10.1029/2007JD009711.

McPeters, R., Kroon, M., Labow, G., Brinksma, E., Balis, D., Petropavlovskikh, I., Veefkind, J.P., Bhartia, P.K., Levelt, P.F., 2008. Validation of the Aura Ozone Monitoring Instrument total column ozone product. J. Geophys. Res. 113, D15S14, doi:10.1029/2007JD008802.

Miettinen, J., Liew, S.C., 2009. Burn-scar patterns and their effect on regional burnt-area mapping in insular South-east Asia. International Journal of Wildland Fire 18, 837847. doi:10.1071/wf08102.

Miller, J.D., Thode, A.E., 2007. Quantifying burn severity in a heterogeneous landscape with a relative version of the delta Normalized Burn Ratio (dNBR). Remote Sensing of Environment 109(1), 66-80.

Millet, D.B., Jacob, D.J., Boersma, K.F., Fu, T.-M., Kurosu, T.P., Chance, K., Heald, C.L., Guenther, A., 2008. Spatial distribution of isoprene emissions from North America derived from formaldehyde column measurements by the OMI satellite sensor. J. Geophys. Res. 113, D02307, doi:10.1029/2007JD008950.

Mims, S.R., Kahn, R.A., Moroney, C.M., Gaitley, B.J., Nelson, D.L., Garay, M.J., 2009. MISR Stereo-heights of grassland fire smoke plumes in Australia. IEEE Trans. Geosci. Remt. Sens. 48, 25-35.

Mishchenko, M.I., Geogdzhayev, I.V., Cairns, B., Rossow, W.B., Lacis, A.A., 1999. Aerosol retrievals over the ocean by use of channels 1 and 2 AVHRR data: sensitivity analysis and preliminary results. Appl. Opt. 38, 7325-7341.

Moody, E. G., King, M. D., Platnick, S., Schaaf, C. B., Gao, F., 2005. Spatially complete global spectral surface albedos: Value-added datasets derived from terra MODIS land products. IEEE Trans. Geosci. Remote Sensing 43, 144-158. 
Morisette, J.T., Giglio, L., Csiszar, I., and Justice, C.O., 2005a. Validation of MODIS active fire detection product over Southern Africa using ASTER data. International Journal of Remote Sensing 26(19), 4239-4264.

Morisette, J.T., Giglio, L., Csiszar, I., Setzer, A., Schroeder, W., Morton, D., Justice, C.O., 2005b. Validation of MODIS active fire detection products derived from two algorithms. Earth Interactions 9, 1-23.

Moroney, C., Davies, R., Muller, J.-P., 2002. MISR stereoscopic image matchers: Techniques and results. IEEE Trans. Geosci. Remote Sens. 40, $1547-1559$.

Morton, D., DeFries, R., Randerson, J., Giglio, L., Schroeder, W., and van der Werf, G., 2008. Agricultural intensification increases fire frequency and combustion completeness of Amazon deforestation. Global Change Biology 14(10), 2262-2275.

Mota, B.W., Pereira, J.M.C., Oom, D., Vasconcelos, M.J.P., and Schultz, M., 2006. Screening the ESA ATSR-2 World Fire Atlas (1997-2002). Atmos. Chem. Phys. 6, 1409-1424, doi:10.5194/acp-6-1409-2006.

Muirhead, K., Cracknell, A., 1985. Straw burning over Great Britain detected by AVHRR. International Journal of Remote Sensing 65, 827-833.

Muller, J.-P., Mandanayake, A., Moroney, C., Davies, R., Diner, D.J., Paradise, S., 2002. Operational retrieval of cloud-top heights using MISR data. IEEE Trans. Geosci. Remote Sens. 40, 1532-1546.

Myhre, G., Berntsen, T.K., Haywood, J.M., Sundet, J.K., Holben, B.N., Johnsrud, M., Stordal, F., 2003. Modeling the solar radiative impact of aerosols from biomass burning during the Southern African Regional Science Initiative (SAFARI-2000) experiment. J. Geophys. Res. 108(D13), 8501, doi:10.1029/2002JD002313.

Nelson, D., Chen, Y., Kahn, R., Diner, D., Mazzoni, D., 2008. Example Applications of the MISR INteractive eXplorer (MINX) Software Tool to Wildfire Smoke Plume Analyses. Remote Sensing of Fire: Science and Application. Edited by W.M. Hao, Proceedings of the SPIE, Vol. 7089, pp. 708909-708909-11.

Nichol, J., 1997. Bioclimatic impacts of the 1994 smoke haze event in Southeast Asia. Atmospheric Environment 31(8), 1209-1219, 10.1016/S1352-2310(96)00260-9.

O’Brien, D.M., Mitchell, R.M., 2003. Atmospheric heating due to carbonaceous aerosol in northern Australia - confidence limits based on TOMS aerosol index and sunphotometer data. Atmospheric Research 66, 21-41.

Omar, A., Winker, D., Kittaka, C., Vaughan, M., Liu, Z., Hu, Y., Trepte, C., Rogers, R., Ferrare, R., Lee, K.-P., Kuehn, R., Hostetler, C., 2009. The CALIPSO automated aerosol classification and lidar ratio selection algorithm. J. Atmos. Ocean. Tech. 26, 1994-2014.

Ottmar, R., Sandberg, D., Riccardi, C., Prichard, S., 2007. An overview of the fuel characteristic classification system: Quantifying, classifying, and creating fuelbeds for resource planning. Can. J. For. Res. 37(12), 2383- 2393.

Palacios-Orueta, A., Parra, A., Chuvieco, E., Carmona-Moreno, C., 2004. Remote sensing and geographic information systems methods for global spatiotemporal modeling of biomass burning emissions: Assessment in the African continent. J. Geophys. Res. 109(D14S09), doi:10.1029/2004JD004734.

Park, M., Randel, W.J., Kinnison, D.E., Garcia, R.R., Choi, W., 2004. Seasonal variation of methane, water vapor, and nitrogen oxides near the tropopause: Satellite 
observations and model simulations. J. Geophys. Res. 109, D03302, doi:10.1029/2003JD003706.

Pereira, G., Freitas, S.R., Moraes, E.C., Ferreira, N.J., Shimabukuro, Y.E., Rao, V.B., Longo, K.M., 2009. Estimating trace gas and aerosol emissions over South America: Relationship between fire radiative energy released and aerosol optical depth observations. Atmospheric Environment 43, 6388-6397.

Perrone, M.R., De Tomasi, F., Burlizzi, P., 2011. Aerosol products by CALIOP at 532 $\mathrm{nm}$ and by a ground-based Raman lidar at $355 \mathrm{~nm}$ : Intercomparison methodology. Atmospheric Research 101, 438-449.

Peterson, D., Wang, J., Ichoku, C., Remer, L. A., 2010. Effects of lightning and other meteorological factors on fire activity in the North American boreal forest: implications for fire weather forecasting Atmos. Chem. Phys. 10, 6873-6888, doi:10.5194/acp-10-6873-2010.

Petrenko, M., Kahn, R., Chin, M., 2011. Use of MODIS AOD to constrain biomass burning emissions in a GOCART model. American Geophys. Union Fall Meeting, San Francisco, CA.

Pfister, G.G., Wiedinmyer, C., Emmons, L. K., 2008. Impacts of the fall 2007 California wildfires on surface ozone: Integrating local observations with global model simulations. Geophys. Res. Lett. 35, L19814, doi:10.1029/2008GL034747.

Popp, C., Hauser, A., Foppa, N., Wunderle, S., 2007. Remote sensing of aerosol optical depth over central Europe from MSG-SEVIRI data and accuracy assessment with ground-based AERONET measurements. J. Geophys. Res. 112, D24S11, doi:10.1029/2007JD008423.

Potter, B.E., Winkler, J.A., Wilhelm, D.F., Shadbolt, R.P., 2008. Computing the lowelevation variant of the Haines index for fire weather forecasts. Weather and Forecasting 23, 159-167.

Pouliot, G., Pace, T., Roy, D., Pierce, T.E., Mobley, D., 2008. Development of a Biomass Burning Emissions Inventory By Combining Satellite and Ground-Based Information. Journal of Applied Remote Sensing. SPIE/International Society for Optical Engineering, Bellingham, WA, 2(1), 021501.

Prins, E.M., Menzel, W.P., 1992. Geostationary Satellite detection of biomass burning in South America. Int. J. of Remote Sensing 13, 2783-2799.

Prins, E.M., Feltz, J.M., Menzel, W.P., Ward, D.E., 1998. An overview of GOES-8 diurnal fire and smoke results for SCAR-B and 1995 fire season in South America. J. Geophys. Res. 103, 31821-31835.

Radke L.F., Clark T.L., Coen J.L., Walther C., Lockwood R.N., Riggan P.J., Brass J.A., Higgins R.G., 2000. The Wildfire Experiment (WiFE): Observations with airborne remote sensors. Canadian Journal of Remote Sensing 26, 406-417.

Radke, L.F., Hegg, A.S., Hobbs, P.V., Penner J.E., 1995. Effects of aging on the smoke from a large forest fire. Atmospheric Research 38, 315-332.

Ramanathan, V., Carmichael, G., 2008. Global and regional climate changes due to black carbon. Nature Geosci. 1, 221-227.

Randerson, J.T., Liu, H., Flanner, M.G., Chambers, S.D., Jin, Y., Hess, P.G., Pfister, G., Mack, M.C., Treseder, K.K., Welp, L.R., Chapin, F.S., Harden, J.W., Goulden, M.L., Lyons, E., Neff, J.C., Schuur, E.A.G., Zender, C.S., 2006. The impact of boreal forest fire on climate warming. Science 314, 1130-1132, doi:10.1126/science.1132075. 
Randriambelo, T., Baldy, S., Bessafi, M., Petit, M., Despinoy, M., 1998. An improved detection and characterization of active fires and smoke plumes in south-eastern Africa and Madagascar. International Journal of Remote Sensing 19(14), 2623-2638.

Reichle, H.G., Jr., Connors, V.S., Holland, J.A., Hypes, W.D., Wallio, H.A., Casas, J.C., Gormsen, B.B., Saylor, M.S., Hesketh, W.D., 1986. Middle and Upper Tropospheric Carbon Monoxide Mixing Ratios as Measured by a Satellite-Borne Remote Sensor During November 1981. J. Geophys. Res. 91(D10), 10,865-10,887, doi:10.1029/JD091iD10p10865.

Reid, J.S., Eck, T.F., Christopher, S.A., Koppmann, R., Dubovik, O., Eleuterio, D.P., Holben, B.N., Reid, E.A., Zhang, J., 2005a. A review of biomass burning emissions part III: intensive optical properties of biomass burning particles. Atmos. Chem. Phys. 5, 827-849.

Reid, J.S., Koppmann, R., Eck, T.F., Eleuterio, D.P., 2005b. A review of biomass burning emissions part II: intensive physical properties of biomass burning particles. Atmos. Chem. Phys. 5, 799-825.

Reid, J.S., Hyer, E.J., Prins, E.M., et al., 2009. Global monitoring and forecasting of biomass-burning smoke: Description and lessons from the Fire Locating and Modeling of Burning Emissions (FLAMBE) program. IEEE J of Sel. Topics in Appl. Earth Obs. and Rem. Sens. 2(3), 144-162.

Reid, J.S., Prins, E.M., Westphal, D.L., Schmidt, C.C., Richardson, K.A., Christopher, S.A., Eck, T.F., Reid, E.A., Curtis, C.A., Hoffman, J.P., 2004. Real-time monitoring of South American smoke particle emissions and transport using a coupled remote sensing/box-model approach. Geophysical Research Letters 31, doi:10.1029/2003GL018845.

Remer, L.A., Kaufman, Y.J., Tanre, D., Mattoo, S., Chu, D.A., Martins, J.V., Li, R.-R., Ichoku, C., Levy, R.C., Kleidman, R.G., Eck, T.F., Vermote, E., Holben, B.N., 2005. The MODIS aerosol algorithm, products, and validation. J. Atmos. Sci., 62, 947-973.

Remer, L.A., Kleidman, R.G., Levy, R.C., Kaufman, Y.J., Tanré, D., Mattoo, S., Martins, J.V., Ichoku, C., Koren, I., Yu, H., Holben, B.N., 2008. Global aerosol climatology from the MODIS satellite sensors. .J. Geophys. Res., 113, D14S07, doi:10.1029/2007JD009661.

Riggan, P., Tissell, R., Lockwood, R., Brass, J., Pereira, J., Miranda, H., Miranda, A., Campos, T., Higgins, R., 2004. Remote measurement of energy and carbon flux from wildfires in Brazil. Ecol. Appl. 14, 3, 855-872.

Roberts, G., Wooster, M.J., 2008. Fire detection and fire characterization over Africa using Meteosat SEVIRI. IEEE Transaction on Geosciences and Remote Sensing 46, $1200-1218$.

Roberts, G., Wooster, M.J., et al., 2005. Retrieval of biomass burning combustion rates and total from fire radiative power observations: Application t southern Africa using geostationary SEVIRI imagery. Journal of Geophysical Research, 110(D21111), doi: 10.1029/2005JD006018.

Rosenfeld, D., 1999. TRMM observed first direct evidence of smoke from forest fires inhibiting rainfall. Geophys. Res. Lett. 26(20), 3105-3108, doi:10.1029/1999GL006066. 
Roy, D.P., Boschetti, L., 2009 Southern Africa Validation of the MODIS, L3JRC and GLOBCARBON Burned Area Products. IEEE Transactions on Geoscience and Remote Sensing 47(4), 1032 - 1044, doi:10.1109/TGRS.2008.2009000.

Roy, D.P., Boschetti, L., Justice, C.O., Ju, J., 2008a. The Collection 5 MODIS Burned Area Product - Global Evaluation by Comparison with the MODIS Active Fire Product. Remote Sens. Environ. 112, 3690-3707.

Roy, D.P., Jin, Y., Lewis, P.E., Justice, C.O., 2005. Prototyping a global algorithm for systematic fire-affected area mapping using MODIS time series data. Remote Sens. Environ. 97,137-162.

Roy, D.P., Lewis, P., Justice, C.O., 2002. Burned area mapping using multi-temporal moderate spatial resolution data - a bi-directional reflectance model-based expectation approach. Remote Sens. Environ 83, pp. 263-286.

Roy, D., Pouliot, G., Mobley, D., Thompson, G., Pierce, T.E., Soja, A.J., Szykman, J.J., Al-Saadi, J., 2008b. Development of Fire Emissions Inventory Using Satellite Data. Chapter 2, Carlos Borrego, Ana Isabel Miranda (ed.), Air Pollution Modeling and its Application XIX. Springer, New York, NY, 217-225.

Saatchi, S., Halligen, K., Despain, D.G., Crabtree, R.L., 2007. Estimation of forest fuel load from radar remote sensing. IEEE Trans. Geosci. Remote Sens. 46(6), 1726.

Schmit, T.J., Li, Jun, Li, Jinlong, Feltz, W.F., Gurka, J.J., Goldberg, M.D., Schrab, K.J., 2008. The GOES-R Advanced Baseline Imager and the Continuation of Current Sounder Products. J. Appl. Meteor. Climatol. 47, 2696-2711.

Schneising, O., Buchwitz, M., Burrows, J.P., Bovensmann, H., Reuter, M., Notholt, J., Macatangay, R., and Warneke, T., 2008. Three years of greenhouse gas columnaveraged dry air mole fractions retrieved from satellite - Part 1: Carbon dioxide, Atmos. Chem. Phys., 8, 3827-3853, doi:10.5194/acp-8-3827-2008.

Schneising, O., Buchwitz, M., Burrows, J.P., Bovensmann, H., Bergamaschi, P., and Peters, W., 2009. Three years of greenhouse gas column-averaged dry air mole fractions retrieved from satellite - Part 2: Methane. Atmos. Chem. Phys. 9, 443-465, doi:10.5194/acp-9-443-2009.

Scholes, R.J., 1995. Greenhouse gas emissions from vegetation fires in southern Africa, Environ.l Monit. Assess. 38, 169-179.

Scholes M., Andreae, M.O., 2000. Biogenic and pyrogenic emissions from Africa and their impact on the global atmosphere. Ambio 29, $23-29$.

Scholes, R. J., Ward, D. E., Justice, C. O., 1996. Emissions of trace gases and aerosol particles due to vegetation burning in southern hemisphere Africa, J. Geophys. Res. 101, 23,677-23, doi:10.1029/95JD02049.

Schroeder, W., Csiszar, I., Giglio, L., Schmidt, C.C., 2010. On the use of fire radiative power, area, and temperature estimates to characterize biomass burning via moderate to coarse spatial resolution remote sensing data in the Brazilian Amazon. J. Geophys. Res. 115, D21121, doi:10.1029/2009JD013769.

Schroeder, W., Csiszar, I., Morisette, J., 2008a. Quantifying the impact of cloud obscuration on remote sensing of active fires in the Brazilian Amazon. Remote Sensing of the Environment 112, 456-470.

Schroeder, W., Giglio, L., Aravéquia, J.A., 2009. Comment on "Reversal of trend of biomass burning in the Amazon" by Ilan Koren, Lorraine A. Remer, and Karla Longo. Geophys. Res. Lett. 36, L03806, doi:10.1029/2008GL035659. 
Schroeder, W., Morisette, J.T., Csiszar, I., Giglio, L., Morton, D., and Justice, C., 2005. Characterizing vegetation fire dynamics in Brazil through multisatellite data: Common trends and practical issues. Earth Interactions 9, Paper No. 13.

Schroeder, W., Prins, E., Giglio, L., Csiszar, I., Schmidt, C., Morisette, J., Morton, D., $2008 \mathrm{~b}$. Validation of GOES and MODIS active fire detection products using ASTER and ETM plus data. Remote Sensing of Environment 112, 2711-2726.

Schroeder, W., Ruminski, M., Csiszar, I., Giglio, L., Prins, E., Schmidt, C., and Morisette, J., 2008c. Validation analyses of an operational fire monitoring product: The Hazard Mapping System. International Journal of Remote Sensing 29(20), 60596066.

Schultz, M.G., 2002. On the use of ATSR fire count data to estimate the seasonal and interannual variability of vegetation fire emissions. Atmos. Chem. Phys. 2, 387-395, doi:10.5194/acp-2-387-2002.

Seiler W., Crutzen, P.J., 1980. Estimates of gross and net fluxes of carbon between the biosphere and the atmosphere from biomass burning. Clim. Change 2, 207- 248.

Setzer, A.W., Malingreau, J.P., 1996. AVHRR monitoring of vegetation fires in the tropics: Toward the development of a global product, Biomass Burning and Global Change, MIT Press, Cambridge, MA, Vol. 1, 25-39.

Setzer, A.W., Pereira, M.C., 1991. Amazonia biomass burnings in 1987 and an estimate of their tropospheric emissions. Ambio 20, 19-22.

Shakesby, R.A., Doerr, S.H., 2006. Wildfire as a hydrological and geomorphological agent, Earth-Science Reviews, 74, pp. 269-307

Siddaway, J.M., Petelina, S.V., 2011. Transport and evolution of the 2009 Australian Black Saturday bushfire smoke in the lower stratosphere observed by OSIRIS on Odin, J. Geophys. Res., 116, D06203, doi:10.1029/2010JD015162.

Simon, M., Plummer, S., Fierens, F., Hoelzemann, J.J., Arino, O., 2004. Burnt area detection at global scale using ATSR-2: The GLOBSCAR products and their qualification. J. Geophys. Res. 109, D14S02, doi:10.1029/2003JD003622.

Simpson, I.J., Akagi, S.K., Barletta, B., Blake, N.J., Choi, Y., Diskin, G. S., Fried, A., Fuelberg, H.E., Meinardi, S., Rowland, F.S., Vay, S.A., Weinheimer, A.J., Wennberg, P.O., Wiebring, P., Wisthaler, A., Yang, M., Yokelson, R.J., and Blake, D.R., 2011 Boreal forest fire emissions in fresh Canadian smoke plumes: $\mathrm{C} 1-\mathrm{C} 10$ volatile organic compounds (VOCs), CO2, CO, NO2, NO, HCN and $\mathrm{CH} 3 \mathrm{CN}$. Atmos. Chem. Phys. 11, 6445-6463, doi:10.5194/acp-11-6445-2011.

Simpson, J., Wiggert, V., 1969. Models of precipitation cumulus towers. Monthly Weath. Rev. 97, 471-489.

Smith, A.M.S., Wooster, M.J., Powell, A.K., Usher, D., 2002. Texture based feature extraction: Application to burn scar detection in Earth observation satellite sensor imagery. International Journal of Remote Sensing 23(8), 1733-1739

Sofiev, M., Vankevich, R., Lotjonen, M., Prank, M., Petukhov, V., Ermakova, T., Koskinen, J., and Kukkonen, J., 2009. An operational system for the assimilation of the satellite information on wild-land fires for the needs of air quality modelling and forecasting. Atmos. Chem. Phys. 9, 6833-6847, doi:10.5194/acp-9-6833-2009.

Soja, A.J., Al-Saadi, J., Giglio, L., et al., 2009. Assessing satellite-based fire data for use in the National Emissions Inventory. J. Appl. Remote Sens. 3, 031504, doi:10.1117/1.3148859 
Soja, A.J., Cofer, W.R., Shugart, H.H., et al., 2004. Estimating fire emissions and disparities in boreal Siberia (1998-2002). J. Geophys. Res. 109, D14S06, doi:10.1029/2004JD004570.

Spichtinger, N., Wenig, M., James, P., et al., 2001. Satellite detection of a continentalscale plume of nitrogen oxides from boreal forest fires. Geophys. Res. Lett. 28, 45794582.

Steyaert, L.T., Hall, F.G., Loveland, T.R., 1997. Land cover mapping, fire regeneration, and scaling studies in the Canadian boreal forest with $1 \mathrm{~km}$ AVHRR and Landsat TM data. J. Geophys. Res. 102(D24), 29581-29598.

Stolle, F., Dennis, R.A., Kurniwan, I., Lambin, E.F., 2004. Evaluation of remote sensingbased active fire datasets in Indonesia. International Journal of Remote Sensing 25, 271-479.

Susskind, J., Barnet, C., Blaisdell, J., 2003. Retrieval of atmospheric and surface parameters from AIRS/ AMSU/HSB data in the presence of clouds. IEEE Trans. Geosci. Remote Sens. 41, 390-409.

Tanré, D., Bréon, F.M., Déuze, J.L., Dubovik, O., Ducos, F., François, P., Goloub, P., Herman, M., Lifermann, A., Waquet, F., 2011. Remote sensing of aerosols by using polarized, directional and spectral measurements within the A-Train: the PARASOL mission. Atmos. Meas. Tech. Discuss. 4, 2037-2069, www.atmos-meas-techdiscuss.net/4/2037/2011/ doi:10.5194/amtd-4-2037-2011.

Tansey, K., et al., 2004. Vegetation burning in the year 2000: Global burned area estimates from SPOT VEGETATION data. J. Geophys. Res. 109, D14S03, doi:10.1029/2003JD003598.

Tansey, K., et al., 2008. A new, global, multi-annual (2000-2007) burnt area product at 1 km resolution. Geophys. Res. Lett. 35, L01401, doi:10.1029/2007GL031567.

Thompson, A. M., Witte, J. C., Hudson, R. D., Guo, H., Herman, J. R., Fujiwara, M., 2001. Tropical tropospheric ozone and biomass burning. Science 291, 2128-2132.

Thonicke, K., Spessa, A., Prentice, I.C., Harrison, S.P., Dong, L., Carmona- Moreno, C., 2010. The influence of vegetation, fire spread and fire behaviour on biomass burning and trace gas emissions. Biogeosciences 7, 1991-2011.

Toon, O.B., Turcon, R.P., Westphal, D., Malone, R., Liu, M.S., 1988. A multidimensional model for aerosols: Description of computational analogs. J. Atmosph. Sci. 45, 2123-2143.

Torres, O., Chen, Z., Jethva, H., Ahn, C., Freitas, S.R., Bhartia, P.K., 2010. OMI and MODIS observations of the anomalous 2008-2009 Southern Hemisphere biomass burning seasons, Atmos. Chem. Phys., 10, 3505-3513, doi:10.5194/acp-10-3505-2010.

Tosca, M.G., Randerson, J.T., Zender, C.S., Nelson, D.L., Diner, D.J., Logan, J.A., 2011. Dynamics of fire plumes and smoke clouds associated with peat and deforestation fires in Indonesia. J. Geophys. Res. 116, D08207, doi:10.1029/2010JD015148.

Trentmann, J., Andreae, M.O., Graf, H.-F., Hobbs, P.V., Ottmar, R.D., Trautmann, T., 2002. Simulation of a biomass-burning plume: Comparison of model results with observations. J. Geophys. Res. 107, doi:10.1029/2001JD000410.

Trentmann, J., Luderer, G., Winterrath, T., Fromm, M.D., Servranckx, R., Textor, C., Herzog, M., Graf, H.-F., Andreae, M.O., 2006. Modeling of biomass smoke injection 
into the lower stratosphere by a large forest fire (Part I): reference simulation. Atmos. Chem. Phys. 6, 5247-5260, doi:10.5194/acp-6-5247-2006.

Tucker, C.J., Pinzon, J.E., Brown, M.E., Slayback, D.A., Pak, E.W., Mahoney, R., Vermote, E.F., El Saleous, N., 2005. An extended AVHRR 8-km NDVI dataset compatible with MODIS and SPOT vegetation NDVI data. International Journal of Remote Sensing 26(20), 4485-4498

Turquety, S., Hurtmans, D., Hadji-Lazaro, J., Coheur, P.-F., Clerbaux, C., Josset, D., Tsamalis, C., 2009. Tracking the emission and transport of pollution from wildfires using the IASI CO retrievals: analysis of the summer 2007 Greek fires, Atmos. Chem. Phys., 9, 4897-4913, doi:10.5194/acp-9-4897-2009.

Urbanski, S.P., Hao, W.M., Nordgren, B., 2011. The wildland fire emission inventory: western United States emission estimates and an evaluation of uncertainty, Atmos. Chem. Phys., 11, 12973-13000, doi:10.5194/acp-11-12973-2011.

Val Martin M., Logan, J.A., Kahn, R.A., Leung, F.-Y., Nelson, D.L., Diner, D.J., 2010. Smoke injection heights from fires in North America: analysis of 5 years of satellite observations. Atmos. Chem. Phys. 10, 1491-1510.

van der A, R.J., Eskes, H.J., Boersma, K.F., van Noije, T.P.C., Van Roozendael, M., De Smedt, I., Peters, D.H.M.U., Meijer, E.W., 2008. Trends, seasonal variability and dominant NOx source derived from a ten year record of NO2 measured from space. J. Geophys. Res. 113, D04302, doi:10.1029/2007JD009021.

van der Werf, G.R., Randerson, J.T., Collatz, G.J., Giglio, L., 2003. Carbon emissions from fires in tropical and subtropical ecosystems. Glob. Change Biol. 9, 547-562.

van der Werf, G.R., Randerson, J.T., Giglio, L., Collatz, G.J., Kasibhatla, P.S., Arellano, A.F., 2006. Interannual variability in global biomass burning emissions from 1997 to 2004. Atmos. Chem. Phys. 6, 3423-3441, doi:10.5194/acp-6-3523-2006.

van der Werf, G.R., Randerson, J.T., Giglio, L., Collatz, G.J., Mu, M., Kasibhatla, P.S., Morton, D.C., DeFries, R.S., Jin, Y., van Leeuwen, T.T., 2010. Global fire emissions and the contribution of deforestation, savanna, forest, agricultural, and peat fires (1997-2009). Atmos. Chem. Phys. 10, 11707-11735, doi:10.5194/acp-10-117072010.

Van Donkelaar, A., Martin, R.V., Brauer, M., Kahn, R., Levy, R., Verduzco, C., Villeneuve, P., 2010. Global estimates of average ground-level fine particulate matter concentrations from satellite-based aerosol optical depth. Environ. Health Perspect. $118,847-855$.

Van Wagtendonk, J., Root, R., Key, C., Running, S., 2004. Comparison of AVIRIS and Landsat ETM + detection capabilities for burn severity. Int. J. Wildland Fire 92, 397408.

Verbyla, D., Kasischke, E.S., Hoy, E.E., 2008. Seasonal and topographic effects on estimating fire severity from Landsat TM/ETM+ data. Int. J. Wildland Fire 17(4), 527-534.

Vermote, E., Ellicott, E., Dubovik, O., Lapyonok, T., Chin, M., Giglio, L., Roberts, and G.J., 2009. An approach to estimate global biomass burning emissions of organic and black carbon from MODIS fire radiative power. J. Geophys. Res. 114, D18205, doi:10.1029/2008JD011188. 
Wang, J., Christopher, S.A., 2006. Mesoscale modeling of Central American smoke transport to the United States, 2: Smoke regional radiative impacts on surface energy budget and boundary layer evolution. J. Geophys. Res. 111, D14S92, 2006.

Wang, J., Christopher, S.A., Nair, U.S., Reid, J.S., Prins, E.M., Szykman, J., Hand, J.L., 2006. Mesoscale modeling of Central American smoke transport to the United States, 1: "top-down" assessment of emission strength and diurnal variation impacts. J. Geophys. Res. 11, D05S17.

Winker, D.M., Hunt, W.H., McGill, M.J., 2007. Initial performance assessment of CALIOP. Geophys. Res. Lett. 34, L19803, doi:10.1029/2007GL030135.

Winker, D.M., Vaughan, M.A., Omar, A., Hu. Y., Powell, K.A., Liu, Z., Hunt, W.H., Young, S.A., 2010. Overview of the CALIPSO Mission and CALIOP Data Processing Algorithms. J. Atmos. Oceanic Technol. 26, 2310-2323. doi: 10.1175/2009JTECHA1281.1.

Wooster, M.J., 2002. Small-scale experimental testing of fire radiative energy for quantifying mass combusted in natural vegetation fires. Geophys. Res. Lett. 29(21), doi:10.1029/2002GL015487.

Wooster M.J., Roberts G., Perry G.L.W., Kaufman Y.J., 2005. Retrieval of biomass combustion rates and totals from fire radiative power observations: 1. FRP derivation and calibration relationships between biomass consumption and fire radiative energy release. Journal of Geophysical Research 110, D24311, doi:10.1029/2005JD006318.

Wooster, M.J., Zhang, Y.-H., 2004. Boreal forest fires burn lessintensely in Russia than in North America. Geophys. Res. Lett. 31, L20505, doi:10.1029/2004GL020805.

Wooster, M.J., Zhukov, B., Oertel, D., 2003. Fire radiative energy for quantitative study of biomass burning: Derivation from the BIRD experimental satellite and comparison to MODIS fire products. Remote Sensing of Environment 86, 83-107.

Xiong, X., Barnet, C., Maddy, E., Sweeney, C., Liu, X., Zhou, L., Goldberg, M., 2008. Characterization and validation of methane products from the Atmospheric Infrared Sounder (AIRS). J. Geophys. Res. 113, G00A01, doi:10.1029/2007JG000500.

$\mathrm{Xu}, \mathrm{W} .$, Wooster, M.J., Roberts, G., Freeborn, P., 2010. New GOES imager algorithms for cloud and active fire detection and fire radiative power assessment across North, South and Central America. Remote Sensing of Environment 114, 1876-1895.

Yokelson, R.J., Burling, I.R., Urbanski, S.P., Atlas, E.L., Adachi, K., Buseck, P.R., Wiedinmyer, C., Akagi, S.K., Toohey, D.W., Wold, C.E., 2011. Trace gas and particle emissions from open biomass burning in Mexico. Atmospheric Chemistry and Physics 11, 6787-6808. doi:10.5194/acp-11-6787-2011, 2011.

Yurganov, L., McMillan, W., Grechko, E., Dzhola, A., 2010. Analysis of global and regional CO burdens measured from space between 2000 and 2009 and validated by ground-based solar tracking spectrometers. Atmos. Chem. Phys. 10, 3479-3494, doi:10.5194/acp-10-3479-2010.

Yurganov, L., Rakitin, V., Dzhola, A., August, T., Fokeeva, E., Gorchakov, G., Grechko, E., Hannon, S., Karpov, A., Ott, L., Semutnikova, E., Shumsky, R., Strow, L., 2011. Satellite- and ground-based CO total column observations over 2010 Russian fires: accuracy of top-down estimates based on thermal IR satellite data. Atmos. Chem. Phys. 11, 7925-7942, doi:10.5194/acp-11-7925-2011. 
Zhang, J., Christopher, S. A., Holben, B., 2001. Intercomparison of aerosol optical thickness derived from GOES 8 imager and ground-based Sun photometers. J. Geophys. Res. 106, 7387- 7398.

Zhang, X., Kondragunta, S., 2008. Temporal and spatial variability in biomass burned areas across the USA derived from the GOES fire product. Remote Sens. Environ. 112, 2886-2897.

Zhang, X., Kondragunta, S., Schmidt, C., Kogan, F., 2008. Near real time monitoring of biomass burning particulate emissions (PM2.5) across contiguous United States using multiple satellite instruments. Atmospheric Environment 42, 6959-6972.

Zhang, Y.-H., Wooster, M. J., Tutubalina, O., Perry, G.L.W., 2003. Monthly burned area and forest fire carbon emission estimates for the Russian Federation from SPOT VGT. Remote Sens. Environ. 87, 1- 15.

Zhukov, B., Lorenz, E., Oertel, D., Wooster, M.J., Roberts, G., 2006. Spaceborne detection and characterization of fires during the Bi-spectral infrared detection (BIRD) experimental small satellite mission (2001-2004). Remote Sens. Environ. 100(1), 29-51. 


\section{Figure Captions}

Figure 1. Global ecosystem map derived from MODIS based on the International Geosphere/Biosphere Program (IGBP) classification scheme.

Figure 2. Fire detection from Aqua MODIS for July 2011 overlaid on a composited surface reflectance map (also from MODIS), showing the fire radiative power (FRP) value ranges for the individual fire pixels. Compared to the map scale, the fire pixels are indicated with relatively large dots to enhance visualization, causing substantial fire-pixel overlap in certain regions.

Figure 3. Top: Global daily total burned area in 2006 from three different products: mod1 $=$ MODIS fire count based estimate using combined Terra (MOD14) and Aqua (MYD14) fire counts; mc45 = burned area product (MCD45, Roy et al., 2008a); and g31d (GFED version 3 daily product). Bottom: Global daily total burned dry mass in 2006 from different combination of burned area as shown in the top panel, the available biomass ( $\mathrm{glc}=$ Global Land Change dataset, asm $=$ A. Soja (2004) medium fire intensity, and g3d = GFED v3 daily) (from Petrenko et al., 2011).

Figure 4. Comparisons of biomass burning AOD from MODIS and GOCART simulations using different dry mass burned (see bottom panel in Figure 1x) and emission factors (gol = emission factors of $\mathrm{BC}, \mathrm{OC}$ and $\mathrm{SO} 2$ used in current GOCART model, see Chin et al., 2004; GFED-3 = emission factors from Andrea and Merlet 2001 used in GFED v3) over the north of Lake Baikal in Russia in 2006-07-20. The last panel shows the probability distribution function of AOD distributions in the regions (from Petrenko et al., 2012, in preparation).

Figure 5. Schematic of an inverse modeling processes (from Dubovik et al., 2008). 


\section{Tables}

Table 1: List of variables related to biomass burning that can be observed/measured from satellite and potentially useful for climate and/or air-quality modeling

\begin{tabular}{|c|c|}
\hline Observable Variable & Acronym/symbol \\
\hline \multicolumn{2}{|l|}{ Active Fire } \\
\hline Fire Location & FL \\
\hline Fire Temperature & FT \\
\hline Fire Area & FA \\
\hline Fire Radiative Power & FRP \\
\hline \multicolumn{2}{|l|}{ Burned Surface } \\
\hline Burned Area & BA \\
\hline Burn Severity & BS \\
\hline \multicolumn{2}{|l|}{ Smoke Plume Dispositions } \\
\hline Near-source Plume Height & $\mathrm{PH}$ \\
\hline Plume Vertical Profile & PVP \\
\hline \multicolumn{2}{|c|}{ Aerosol Distribution and Particle Properties } \\
\hline Aerosol Index & $\mathrm{AI}$ \\
\hline Aerosol Optical Depth or Thickness & AOD or AOT \\
\hline Aerosol Absorption Optical Depth & AAOD \\
\hline Aersol Effective Radius & $\mathrm{R}_{\text {eff }}$ \\
\hline Aerosol Fine Mode Fraction & FMF \\
\hline Aerosol Type & AType \\
\hline Aerosol Angstrom Exponent & Aexp \\
\hline Aerosol Single Scattering Albedo & SSA or $\omega_{0}$ \\
\hline \multicolumn{2}{|l|}{ Trace Gas Concentrations } \\
\hline Carbon Monoxide & $\mathrm{CO}$ \\
\hline Carbon Dioxide & $\mathrm{CO}_{2}$ \\
\hline Methane & $\mathrm{CH}_{4}$ \\
\hline Nitrogen Oxides & $\mathrm{NO}_{\mathrm{x}}$ \\
\hline Formaldehyde & $\mathrm{HCHO}$ \\
\hline Ozone & $\mathrm{O}_{3}$ \\
\hline
\end{tabular}


Table 2: Various satellites and their respective onboard sensors capable of providing data related to fires and smoke

\begin{tabular}{|c|c|c|c|c|c|}
\hline Satellite & $\begin{array}{l}\text { Launch } \\
\text { Date* }\end{array}$ & Orbit** & Sensor & $\begin{array}{c}\text { Revisit Freq } \\
\text { D:Daytime N:Nighttime }\end{array}$ & $\begin{array}{l}\text { Observed } \\
\text { Variables }\end{array}$ \\
\hline $\operatorname{DMSP}(8-15)$ & 1972 & $\mathrm{P}$ & OLS & D:1 day, & FL \\
\hline Landsat(1-7) & 1972 & $\mathrm{P}$ & $\begin{array}{l}\text { MSS, TM, } \\
\text { ETM, ETM+ }\end{array}$ & D:16 days, $\quad \mathrm{N}: 16$ days & $\mathrm{BA}, \mathrm{BS}$ \\
\hline Nimbus -7 & 1978 & $\mathrm{P}$ & TOMS & D:1 day, $\quad \mathrm{N}: 1$ day & AI, O3 \\
\hline $\begin{array}{l}\text { TIROS-N/ } \\
\text { NOAA(6-19) }\end{array}$ & 1978 & $\mathrm{P}$ & AVHRR & D:1-2 days, N:1-2 days & FL, AOD \\
\hline Meteor-3 & 1991 & $\mathrm{P}$ & TOMS & D:1day, $\quad \mathrm{N}: 1$ day & $\mathrm{AI}, \mathrm{O} 3$ \\
\hline GOES(8-15) & 1994 & G & IMAGER & $\mathrm{D}: 30 \min \quad \mathrm{N}: 30 \mathrm{~min}$ & $\begin{array}{l}\text { FL, FA, FT, FRP, } \\
\text { AOD }\end{array}$ \\
\hline ERS-2 & 1995 & $\mathrm{P}$ & $\begin{array}{l}\text { ATSR-2 } \\
\text { GOME }\end{array}$ & $\begin{array}{l}\mathrm{D} / \mathrm{N}: 3,35 \text {, or } 336 \text { days } \\
\mathrm{D} / \mathrm{N}: 35 \text { days }\end{array}$ & $\begin{array}{l}\mathrm{FL} \\
\mathrm{O} 3, \mathrm{NOx}\end{array}$ \\
\hline EarthProbe & 1996 & $\mathrm{P}$ & TOMS & D:1-2 days, $\mathrm{N}: \mathrm{N} / \mathrm{A}$ & $\mathrm{AI}, \mathrm{O} 3$ \\
\hline ADEOS-1 & 1996 & $\mathrm{P}$ & POLDER-1 & D:1-2 days, N:N/A & AOD, FMF, Aexp \\
\hline TRMM & 1997 & I-35 & VIRS & D:1-2 days, $N: 1-2$ days & FL \\
\hline SPOT4 & 1998 & $\mathrm{P}$ & VGT1 & $\mathrm{D}: 1$ day, $\mathrm{N}: 1$ day & BA \\
\hline \multirow[t]{4}{*}{ Terra } & 1999 & $\mathrm{P}$ & MODIS & D:1-2 days, $\mathrm{N}: 1-2$ days & $\begin{array}{l}\text { FL, FRP, BA, } \\
\text { AOD, Aexp (over } \\
\text { water), FMF }\end{array}$ \\
\hline & & $\mathrm{P}$ & MISR & D:8 days, $\mathrm{N}: \mathrm{N} / \mathrm{A}$ & $\begin{array}{l}\text { PH, AOD, Atype, } \\
\text { Aexp, FMF }\end{array}$ \\
\hline & & $\mathrm{P}$ & MOPITT & D:3-5 days, $N: 3-5$ days & $\mathrm{CO}, \mathrm{CH} 4$ \\
\hline & & $\mathrm{P}$ & ASTER & D:16 days, $N: 16$ days & FL, BA \\
\hline BIRD & 2001 & $\mathrm{P}$ & HSRS & N/A & FL, FRP \\
\hline Odin & 2001 & $\mathrm{P}$ & OSIRIS & & $\mathrm{PVP}, \mathrm{NO} 2, \mathrm{O} 3$ \\
\hline ADEOS-2 & 2002 & $\mathrm{P}$ & POLDER-2 & D:1-2 days, N:N/A & AOD, FMF, Aexp \\
\hline SPOT5 & 2002 & $\mathrm{P}$ & VGT2 & $\mathrm{D}: 1$ day, $\mathrm{N}: 1$ day & BA \\
\hline \multirow[t]{2}{*}{ Aqua } & 2002 & $\mathrm{P}$ & MODIS & $\mathrm{D}: 1-2$ days, $\mathrm{N}: 1-2$ days & $\begin{array}{l}\text { FL, FRP, BA, } \\
\text { AOD }\end{array}$ \\
\hline & & $\mathrm{P}$ & AIRS & D:1-2 days, $\mathrm{N}: 1-2$ days & $\mathrm{CO}, \mathrm{CO} 2, \mathrm{CH} 4$ \\
\hline \multirow[t]{2}{*}{ Envisat } & 2002 & $\mathrm{P}$ & SCIAMACHY & D:1-2 days, $\mathrm{N}: \mathrm{N} / \mathrm{A}$ & $\begin{array}{l}\mathrm{CO}, \mathrm{CO} 2, \mathrm{CH} 4 \\
\mathrm{HCHO}, \mathrm{O} 3\end{array}$ \\
\hline & & & MERIS & D:2-3 days, N:N/A & $\mathrm{AOD}$ \\
\hline ICESat & 2003 & & GLAS & N/A & PTH, PVP \\
\hline MSG & 2004 & G & SEVIRI & $\mathrm{D}: 15 \min , \mathrm{N}: 15 \mathrm{~min}$ & FL, FRP \\
\hline \multirow[t]{2}{*}{ Aura } & 2004 & $\mathrm{P}$ & OMI & D:1-2 days, N:N/A & $\begin{array}{l}\text { AI, AOD, AAOD, } \\
\text { NO2, O3 }\end{array}$ \\
\hline & & $P$ & TES & D:16 days, $\mathrm{N}: 16$ days & $\mathrm{CO}, \mathrm{CH} 4$ \\
\hline Parasol & 2006 & $\mathrm{P}$ & POLDER & D:1-2 days, $N: N / A$ & AOD, FMF, Aexp \\
\hline MetOp & 2006 & $\mathrm{P}$ & IASI & D:1 day, N:1 day & $\mathrm{CO}, \mathrm{CH} 4$ \\
\hline Calipso & 2006 & $\mathrm{P}$ & CALIOP & N/A & PVP, AOD \\
\hline
\end{tabular}

*For a series of similar satellites, only the launch date of the first one in the series is shown.

$* * \mathrm{P}=$ polar orbiters; $\mathrm{G}=$ Geostationary; $\mathrm{I}-35=$ orbit inclined at 35 degrees from equatorial plane

$\sim$ Revisit Frequency represents the time interval between which the same spot on earth is observed consecutive times. Only active sensors or passive sensors with infrared (IR) capability have been identified with Nighttime (N:) revisit.

N/A = Not Applicable or Not Available. 
Table 3: Acronyms of Satellites and Sensors described in this paper, preceded by those of the Agencies that operate these Satellites and the respective Countries or Regions they belong to.

\begin{tabular}{|c|c|c|}
\hline Agency & Description & Country/Region \\
\hline CNES & Centre Nationale d'Etudes Spatiales & France \\
\hline CSA & Canadian Space Agency & Canada \\
\hline ESA & European Space Agency & Europe \\
\hline NASA & National Aeronautics and Space Administration & USA \\
\hline NOAA & National Oceanic and Atmospheric Administration & USA \\
\hline USGS & United States Geological Surveys & USA \\
\hline Satellite & Description & Agency \\
\hline ADEOS & Advanced Earth Observing Satellite (I and II) & JAXA \\
\hline Aqua & $\mathrm{N} / \mathrm{A}^{*}$ & NASA \\
\hline Aura & N/A & NASA \\
\hline CALIPSO & Cloud-Aerosol Lidar and Infrared Pathfinder Satellite Observations & NASA, CNES \\
\hline DMSP & Defense Meteorological Satellite Program & NOAA \\
\hline Envisat & Environmental Satellite & ESA \\
\hline EP & Earth Probe & NASA \\
\hline ERS-2 & Second European Remote-Sensing Satellite & ESA \\
\hline ICESat & Ice, Clouds, and Land Elevation Satellite & NASA \\
\hline ICESat & Ice, Cloud,and land Elevation Satellite & NASA \\
\hline Landsat & N/A (series 1 to 7 , except 6 ) & USGS \\
\hline Meteor-3 & N/A & NASA \\
\hline MetOp & Meteorological Operational satellite programme & ESA \\
\hline MSG & Meteosat Second Generation & ESA \\
\hline Nimbus-7 & N/A & NASA \\
\hline NOAA & National Oceanic and Atmospheric Administration (series 1 - 19) & NOAA \\
\hline Odin & $\mathrm{N} / \mathrm{A}$ & CSA \\
\hline & Polarization and Anisotropy of Reflectance for Atmospheric Science coupled with & \\
\hline PARASOL & Observations from a Lidar & CNES \\
\hline SeaStar & N/A & NASA \\
\hline Terra & N/A & NASA \\
\hline TIROS-N & Television InfraRed Operational Satellite - Next-generation & NASA \\
\hline TRMM & Tropical Rainfall Measuring Mission & NASA \\
\hline UARS & Upper Atmosphere Research Satellite & NASA \\
\hline AMSR-E & Advanced Microwave Scanning Radiometer - Earth Observing System & Aqua \\
\hline AMSU & Advanced Microwave Sounding Unit & Aqua \\
\hline ASTER & Advanced Spaceborne Thermal Emission and Reflection radiometer & Terra \\
\hline ATSR & Along Track Scanning Radiometer & ERS-2 \\
\hline AVHRR & Advanced Very High Resolution Radiometer & NOAA \\
\hline CALIOP & Cloud and Aerosol Lidar with Orthogonal Polarization & CALIPSO \\
\hline ETM+ & Enhanced Thematic Mapper & Landsat \\
\hline ETM+ & Enhanced Thematic Mapper plus & Landsat \\
\hline GLAS & Geoscience Laser Altimeter System & ICESat \\
\hline GOME & Global Ozone Monitoring Experiment & ERS \\
\hline GOME-2 & Global Ozone Monitoring Experiment-2 & MetOp \\
\hline IASI & Infrared Atmospheric Sounding Interferometer & MetOp \\
\hline IMG & Imager & GOES \\
\hline MERIS & Medium Resolution Imaging Spectrometer & Envisat \\
\hline MISR & Multi-angle Imaging Spectroradiometer & Terra \\
\hline MODIS & Moderate-resolution Imaging Spectroradiometer & Terra, Aqua \\
\hline MOPITT & Measurements of Pollution in the Troposphere & Terra \\
\hline MSS & Multi-Spectral Scanner & Landsat \\
\hline OMI & Ozone Monitoring Instrument & Aura \\
\hline OSIRIS & Optical Spectrograph and Infra-Red Imaging System & Odin \\
\hline POLDER & Polarization and Directionality of the Earth Reflectances & ADEOS, Parasol \\
\hline SCIAMACHY & SCanning Imaging Absorption SpectroMeter for Atmospheric ChartographY & Envisat \\
\hline SeaWiFS & Sea-viewing Wide Field-of-view Sensors & SeaStar \\
\hline SEVIRI & Spinning Enhanced Visible and Infrared Imager & MSG \\
\hline TES & Tropospheric Emission Spectrometer & Aura \\
\hline TM & Thematic Mapper & Landsat \\
\hline TOMS & Total Ozone Mapping Spectrometer & Nimbus-7, Meteor-3, EP \\
\hline VIIRS & Visible Infrared Imager Radiometer Suite & NPP \\
\hline VIRS & Visible and Infrared Scanner & TRMM \\
\hline
\end{tabular}


Table 4a: Satellite measurements of variables related to fires and burned surfaces. See acronyms in Tables 1 and 3.

\begin{tabular}{|c|c|c|c|c|c|}
\hline Variable & Sensor (Satellites) & $\begin{array}{c}\text { Nominal } \\
\text { Spatial Res }\end{array}$ & $\begin{array}{c}\text { Spatial } \\
\text { Coverage }\end{array}$ & Data Period* & References** \\
\hline \multirow{8}{*}{$\begin{array}{l}\text { Fire } \\
\text { Location } \\
(\text { FL) }\end{array}$} & OLS (DMSP) & $2.7 \times 2.7 \mathrm{~km}$ & & 1979-1992 & Cahoon et al. (1992a,b) \\
\hline & $\begin{array}{c}\text { AVHRR (TIROS- } \\
\text { N/NOAA-6 ...NOAA-19) }\end{array}$ & $1 \mathrm{x} 1 \mathrm{~km}$ & Global & 1992- & $\begin{array}{l}\text { Setzer et al. (1996); } \\
\text { Steyaert et al. (1997) }\end{array}$ \\
\hline & MODIS (Terra \& Aqua) & $1 \mathrm{x} 1 \mathrm{~km}$ & Global & 2000-Present & $\begin{array}{l}\text { Kaufman et al. (1998a); } \\
\text { Justice et al. (2002); Giglio } \\
\text { et al. (2003a) }\end{array}$ \\
\hline & VIRS (TRMM) & 2.4 x $2.4 \mathrm{~km}$ & $40 \mathrm{~N}-40 \mathrm{~S}$ & 1997- & Giglio et al. (2003b) \\
\hline & ASTER (Terra) & $0.03 \times 0.03 \mathrm{~km}$ & Global & 2000-Present & Morisette et al. $(2005 a, b)$ \\
\hline & HSRS (BIRD) & $0.37 \times 0.37 \mathrm{~km}$ & & & Wooster et al. (2003) \\
\hline & IMG (GOES) & $4 \times 4 \mathrm{~km}$ & $\begin{array}{l}\text { North and } \\
\text { South } \\
\text { America }\end{array}$ & & Prins and Menzel (1992); \\
\hline & SEVIRI (MSG) & $3 \times 3 \mathrm{~km}$ & $\begin{array}{l}\text { Africa \& } \\
\text { Europe }\end{array}$ & 2004-Present & Roberts et al. (2005); \\
\hline \multirow[t]{3}{*}{$\begin{array}{l}\text { Fire } \\
\text { Radiative } \\
\text { Power } \\
\text { (FRP) }\end{array}$} & MODIS (Terra \& Aqua) & $1 \times 1 \mathrm{~km}$ & Global & 2000-Present & $\begin{array}{l}\text { Kaufman et al. (1998a); } \\
\text { Justice et al. (2002); Giglio } \\
\text { et al. (2003a); Ichoku et al. } \\
\text { (2008a) }\end{array}$ \\
\hline & HSRS (BIRD) & $0.37 \times 0.37 \mathrm{~km}$ & & & Wooster et al. (2003) \\
\hline & SEVIRI (MSG) & $3 \times 3 \mathrm{~km}$ & $\begin{array}{l}\text { Africa \& } \\
\text { Europe }\end{array}$ & 2004-Present & Roberts et al. (2005) \\
\hline \multirow{2}{*}{$\begin{array}{l}\text { Fire Area } \\
\text { and } \\
\text { Temperature } \\
(\text { FA, FT) }\end{array}$} & IMG (GOES) & $4 \mathrm{x} 4 \mathrm{~km}$ & $\begin{array}{l}\text { North and } \\
\text { South } \\
\text { America }\end{array}$ & & \\
\hline & ASTER (Terra) & $0.03 \times 0.03 \mathrm{~km}$ & Global & 2000-Present & Eckmann et al., 2009 \\
\hline \multirow[t]{2}{*}{$\begin{array}{l}\text { Burned } \\
\text { Area (BA) }\end{array}$} & MODIS (Terra \& Aqua) & $0.5 \times 0.5 \mathrm{~km}$ & Global & 2000-Present & $\begin{array}{l}\text { Roy et al. (2005, 2008a), } \\
\text { Roy and Boschetti (2009). }\end{array}$ \\
\hline & VEG (SPOT) & $1 \mathrm{x} 1 \mathrm{~km}$ & Global & 2000-Present & Tansey et al. (2004) \\
\hline $\begin{array}{l}\text { Burn } \\
\text { Severity } \\
\text { (BS) }\end{array}$ & TM, ETM (Landsat) & $0.03 \times 0.03 \mathrm{~km}$ & Global & 1972-Present & $\begin{array}{l}\text { French et al. (2008); } \\
\text { Verbyla et al. (2008). }\end{array}$ \\
\hline
\end{tabular}

*Data period is the estimated period of data coverage based on available publication or web references, but does not verify whether or not the data is actually available.

** References cited here are just examples, and do not represent endorsement of validity. 
Table 4b: Satellite measurements of variables related to smoke plumes, aerosol particles, and trace gases.

For aerosols, only AI and AOD are shown to save space. See Acronyms in Tables 1 and 3.

\begin{tabular}{|c|c|c|c|c|c|}
\hline Variable & Sensor (Satellites) & $\begin{array}{c}\text { Nominal Spatial } \\
\text { Res }\end{array}$ & $\begin{array}{c}\text { Spatial } \\
\text { Coverage }\end{array}$ & Data Period* & References** \\
\hline $\mathrm{PH}$ & MISR (Terra) & $1.1 \times 1.1 \mathrm{~km}$ & Global & 2000 - Present & $\begin{array}{l}\text { Kahn et al. (2007; 2008); } \\
\text { Val Martin et al., (2010) }\end{array}$ \\
\hline PVP & CALIOP (Calipso) & N/A & $\begin{array}{l}\text { Global } \\
\text { (curtains) }\end{array}$ & 2006 - Present & Winker et al. $(2007,2009)$ \\
\hline AI & $\begin{array}{c}\text { OMI (Aura) } \\
\text { TOMS (Nimbus-7, Meteor- } \\
\text { 3, Earth Probe) }\end{array}$ & $\begin{array}{l}13 \times 24 \mathrm{~km} \\
50 \times 50 \mathrm{~km}\end{array}$ & $\begin{array}{l}\text { Global } \\
\text { Global }\end{array}$ & $\begin{array}{l}2004 \text {-Present } \\
1978 \text { - Present }\end{array}$ & $\begin{array}{l}\text { Torres et al. }(2010) \\
\text { Hsu et al. }(1996,1999)\end{array}$ \\
\hline \multirow[t]{9}{*}{ AOD } & MODIS (Terra and Aqua) & $10 \times 10 \mathrm{~km}$ & Global & 2000 - Present & $\begin{array}{c}\text { Remer et al. }(2005,2008), \\
\text { Levy et al. }(2010) .\end{array}$ \\
\hline & MISR (Terra) & $18 \times 18 \mathrm{~km}$ & Global & 2000 - Present & Kahn et al. (2009; 2010) \\
\hline & OMI (Aura) & $13 \times 24 \mathrm{~km}$ & Global & 2004 -Present & Torres et al. (2010) \\
\hline & $\begin{array}{l}\text { POLDER (ADEOS1, } \\
\text { ADEOS2, PARASOL) }\end{array}$ & $19 \times 19 \mathrm{~km}$ & $\begin{array}{c}\text { Global } \\
\text { (Ocean only) }\end{array}$ & $1996-2010$ & Tanre et al. (2011) \\
\hline & SEAWiFS (SeaStar) & $4 \times 4 \mathrm{~km}$ & Global & $1997-2010$ & \\
\hline & AVHRR (NOAA) & $8 \times 8 \mathrm{~km}$ & $\begin{array}{c}\text { Global } \\
\text { (Ocean only) }\end{array}$ & 1988 - Present & $\begin{array}{l}\text { Ignatov et al. (2004); } \\
\text { Mishchenko et al (1999) }\end{array}$ \\
\hline & SEVIRI (MSG) & $3 \times 3 \mathrm{~km}$ & $\begin{array}{l}\text { Africa, } \\
\text { Europe }\end{array}$ & & Popp et al. (2007) \\
\hline & IMG (GOES) & $4 \times 4 \mathrm{~km}$ & N/S America & & Zhang et al. (2001) \\
\hline & CALIOP (Calipso) & $5 \times 5 \mathrm{~km}$ & $\begin{array}{c}\text { Global } \\
\text { (curtains) }\end{array}$ & 2006 - Present & Winker et al., $(2007,2009)$ \\
\hline \multirow[t]{2}{*}{$\mathrm{CO}_{2}$} & AIRS (Aqua) & $90 \times 90 \mathrm{~km}$ & Global & 2002 - Present & Chahine et al. (2008) \\
\hline & SCIAMACHY (Envisat) & $30 \times 120 \mathrm{~km}$ & Global & 2003 - Present & $\begin{array}{l}\text { Buchwitz et al. (2005a,b, } \\
\text { 2006) }\end{array}$ \\
\hline \multirow[t]{4}{*}{$\mathrm{CO}$} & MOPITT (Terra) & $22 \mathrm{~km} \times 22 \mathrm{~km}$ & Global & 2000 - Present & Edwards et al. (2004) \\
\hline & AIRS (Aqua) & $50 \times 50 \mathrm{~km}$ & Global & 2002 - Present & McMillan et al. (2005) \\
\hline & TES (Aura) & $5 \times 8 \mathrm{~km}$ & Global & 2004 - Present & Lopez et al. (2008) \\
\hline & SCIAMACHY (Envisat) & $30 \times 120 \mathrm{~km}$ & Global & 2003 - Present & $\begin{array}{c}\text { Buchwitz et al. (2005a,b, } \\
\text { 2006) }\end{array}$ \\
\hline \multirow[t]{4}{*}{$\mathrm{CH}_{4}$} & MOPITT (Terra) & $22 \mathrm{~km} \times 22 \mathrm{~km}$ & Global & 2000 - Present & Edwards et al. (2004) \\
\hline & AIRS (Aqua) & $50 \times 50 \mathrm{~km}$ & Global & 2002 - Present & Xiong et al. (2008) \\
\hline & TES (Aura) & $5 \times 8 \mathrm{~km}$ & Global & 2004 - Present & \\
\hline & SCIAMACHY (Envisat) & $30 \times 120 \mathrm{~km}$ & Global & 2003 - Present & $\begin{array}{c}\text { Buchwitz et al. (2005a,b, } \\
\text { 2006) }\end{array}$ \\
\hline \multirow[t]{2}{*}{$\mathrm{NO}_{\mathrm{x}}$} & GOME (ERS-2) & $40 \mathrm{~km} \times 40 \mathrm{~km}$ & Global & 1995 - Present & Martin et al. $(2003,2004)$ \\
\hline & SCIAMACHY (Envisat) & $30 \times 120 \mathrm{~km}$ & Global & 2003 - Present & van der A et al. (2008) \\
\hline \multirow[t]{3}{*}{$\mathrm{HCHO}$} & OMI (Aura) & $13 \times 24 \mathrm{~km}$ & Global & 2004 -Present & Millet et al. (2008) \\
\hline & GOME (ERS-2) & $40 \mathrm{~km} \times 40 \mathrm{~km}$ & Global & 1995 - Present & Martin et al. (2004) \\
\hline & SCIAMACHY (Envisat) & $30 \times 60 \mathrm{~km}$ & Global & 2003 - Present & Dufour et al. (2009) \\
\hline \multirow[t]{5}{*}{$\mathrm{O}_{3}$} & OMI (Aura) & $13 \times 24 \mathrm{~km}$ & Global & 2004 -Present & McPeters et al. (2008) \\
\hline & $\begin{array}{l}\text { TOMS (Nimbus-7, Meteor- } \\
\text { 3, Earth Probe) }\end{array}$ & $50 \times 50 \mathrm{~km}$ & Global & 1978 - Present & Bhartia (2007) \\
\hline & SCIAMACHY (Envisat) & $30 \times 120 \mathrm{~km}$ & Global & 2002 - Present & Brinksma et al. (2006) \\
\hline & TES (Aura) & $5 \times 8 \mathrm{~km}$ & Global & 2004 - Present & Bowman et al. (2002) \\
\hline & GOME (ERS-2) & $40 \mathrm{~km} \mathrm{x} 40 \mathrm{~km}$ & Global & 1995 - Present & Liu et al. (2006) \\
\hline
\end{tabular}

*Data period is the estimated period of data coverage based on available publication or web references, but does not verify whether or not the data is actually available.

**References cited here are just examples, and do not represent endorsement of validity. 
Table 5: Relationship between model inputs and the Closest Satellite Equivalent (CSE) measurements

\begin{tabular}{|c|c|c|c|c|}
\hline Model Input & $\begin{array}{l}\text { Typical } \\
\text { Model } \\
\text { Units }\end{array}$ & $\begin{array}{l}\text { Closest Satellite } \\
\text { Equivalent }\end{array}$ & $\begin{array}{l}\text { Typical } \\
\text { Satellite } \\
\text { Units }\end{array}$ & Comments \\
\hline \multicolumn{5}{|l|}{ Active Fire } \\
\hline Radiant Energy Flux & Watts & Fire radiative power & Watts & $\begin{array}{l}\text { Underestimated in cloudy } \\
\text { and heavy smoke areas }\end{array}$ \\
\hline Sensible heat & Joules & N/A & & \\
\hline Latent heat & Joules & N/A & & \\
\hline Fire size & $\mathrm{km}^{2}$ & Fire (pixel) counts & unitless & Only proxies \\
\hline Fire rate of spread & $\mathrm{m} / \mathrm{min}$ & N/A & & \\
\hline Fire duration & & Fire persistence & & $\begin{array}{l}\text { Only in some areas from } \\
\text { Geostationary satellites }\end{array}$ \\
\hline \multicolumn{5}{|l|}{ Fuel and Burned surface } \\
\hline Burned area & $\mathrm{km}^{2}$ & Burned area & $\mathrm{km}^{2}$ & \\
\hline Biomass Density & $\mathrm{g} / \mathrm{m}^{2}$ & Vegetation Indices & unitless & Only proxies \\
\hline Fuel Type & category & $\begin{array}{l}\text { Satellite-derived } \\
\text { vegetation/landcover } \\
\text { maps }\end{array}$ & & \\
\hline Fuel Load & $\mathrm{g} / \mathrm{m}^{2}$ & N/A & & \\
\hline Fuel moisture content & $\%$ & N/A & & \\
\hline Burn efficiency & ratio & Burn severity & & Only proxies \\
\hline Calorific heat content & $\mathrm{kJ} / \mathrm{kg}$ & N/A & & \\
\hline \multicolumn{5}{|l|}{ Smoke Plume } \\
\hline Plume Injection Height & $\mathrm{m}$ & $\begin{array}{l}\text { Near-source Plume } \\
\text { height }\end{array}$ & $\mathrm{m}$ & Only from MISR \\
\hline Plume Vertical Profile & & Plume curtain slice & & $\begin{array}{l}\text { Only from lidar; mainly } \\
\text { downwind of source }\end{array}$ \\
\hline \multicolumn{5}{|l|}{ Emissions } \\
\hline Emission rate & $\mathrm{kg} / \mathrm{s}$ & $\begin{array}{l}\text { Emission rate (based } \\
\text { on instantaneous near- } \\
\text { source plume AOD) }\end{array}$ & $\mathrm{kg} / \mathrm{s}$ & $\begin{array}{l}\text { Still being investigated } \\
\text { (requires model to } \\
\text { interpret) }\end{array}$ \\
\hline Emission factor & $\mathrm{g} / \mathrm{kg}$ & $\begin{array}{l}\text { Emission coefficient } \\
\text { (based on FRP) }\end{array}$ & $\mathrm{kg} / \mathrm{MJ}$ & $\begin{array}{l}\text { Still being investigated } \\
\text { (e.g., Ichoku and } \\
\text { Kaufman, 2005) }\end{array}$ \\
\hline
\end{tabular}

$\mathrm{N} / \mathrm{A}=$ Not available or not applicable 


\section{Figures}

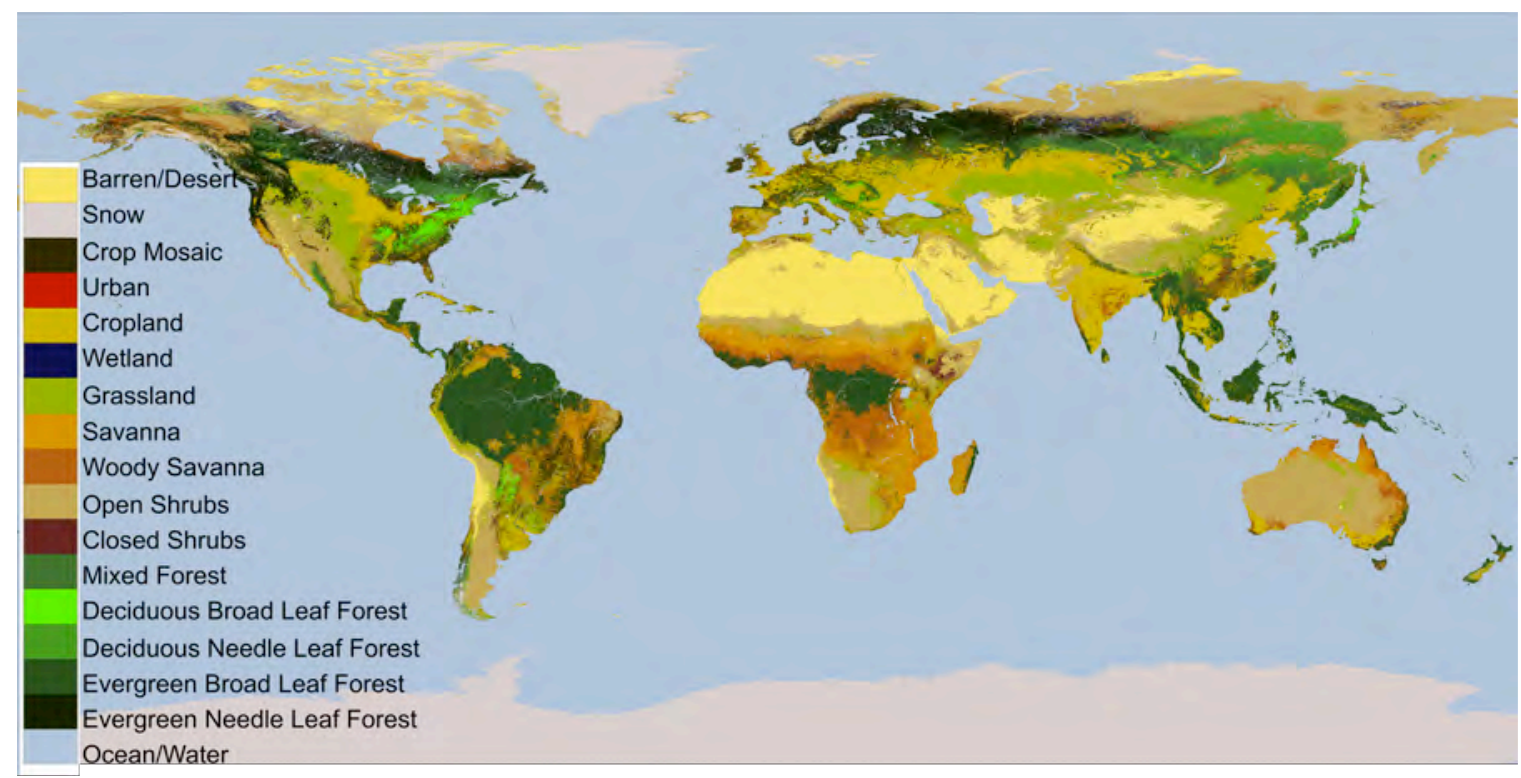

Fig. 1: Global ecosystem map derived from MODIS based on the International Geosphere/Biosphere Program (IGBP) classification scheme. 


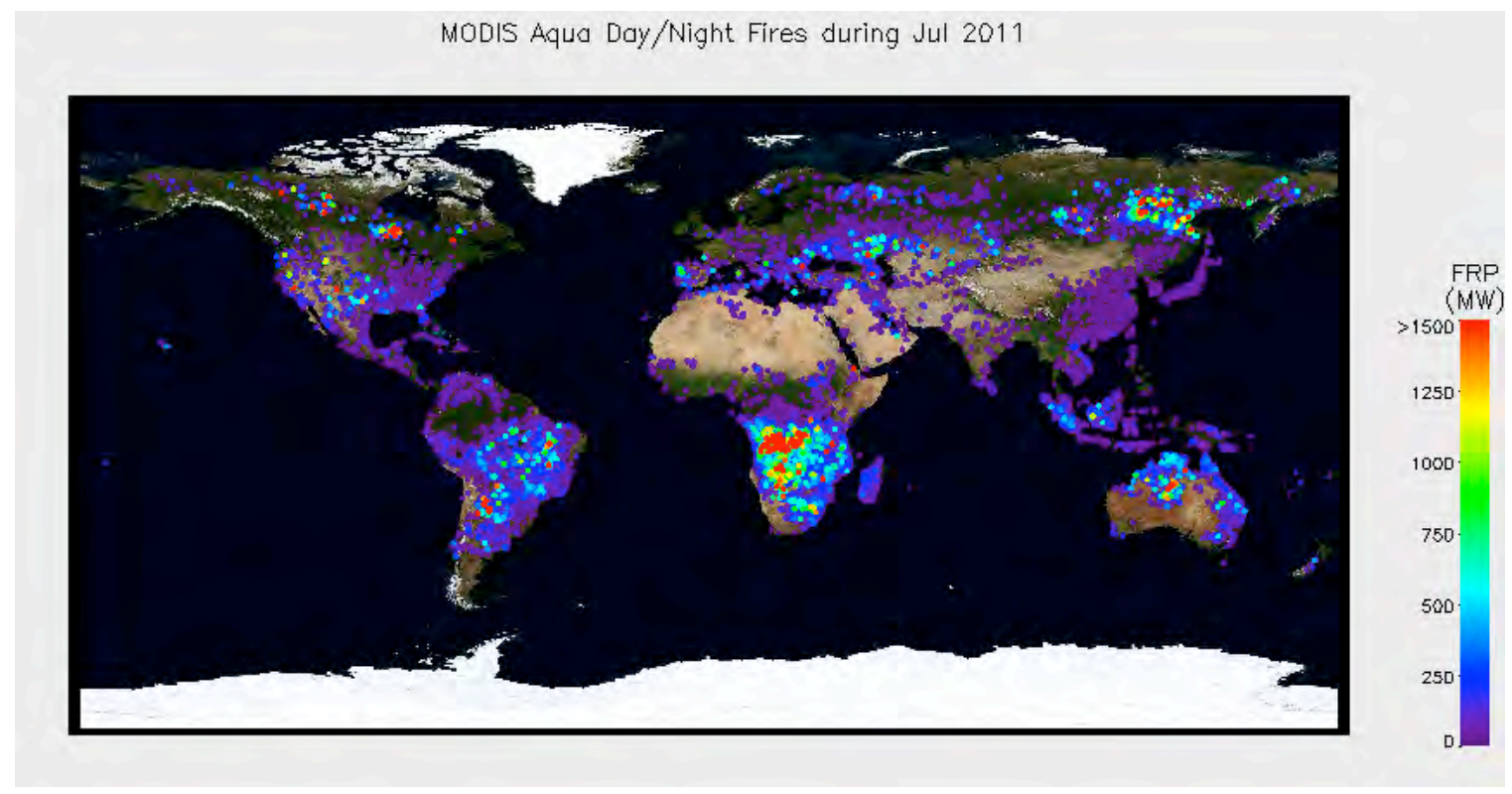

Fig. 2: Fire detection from Aqua MODIS for July 2011 overlaid on a composited surface reflectance map (also from MODIS), showing the fire radiative power (FRP) value ranges for the individual fire pixels. Compared to the map scale, the fire pixels are indicated with relatively large dots to enhance visualization, causing substantial firepixel overlap in certain regions. 

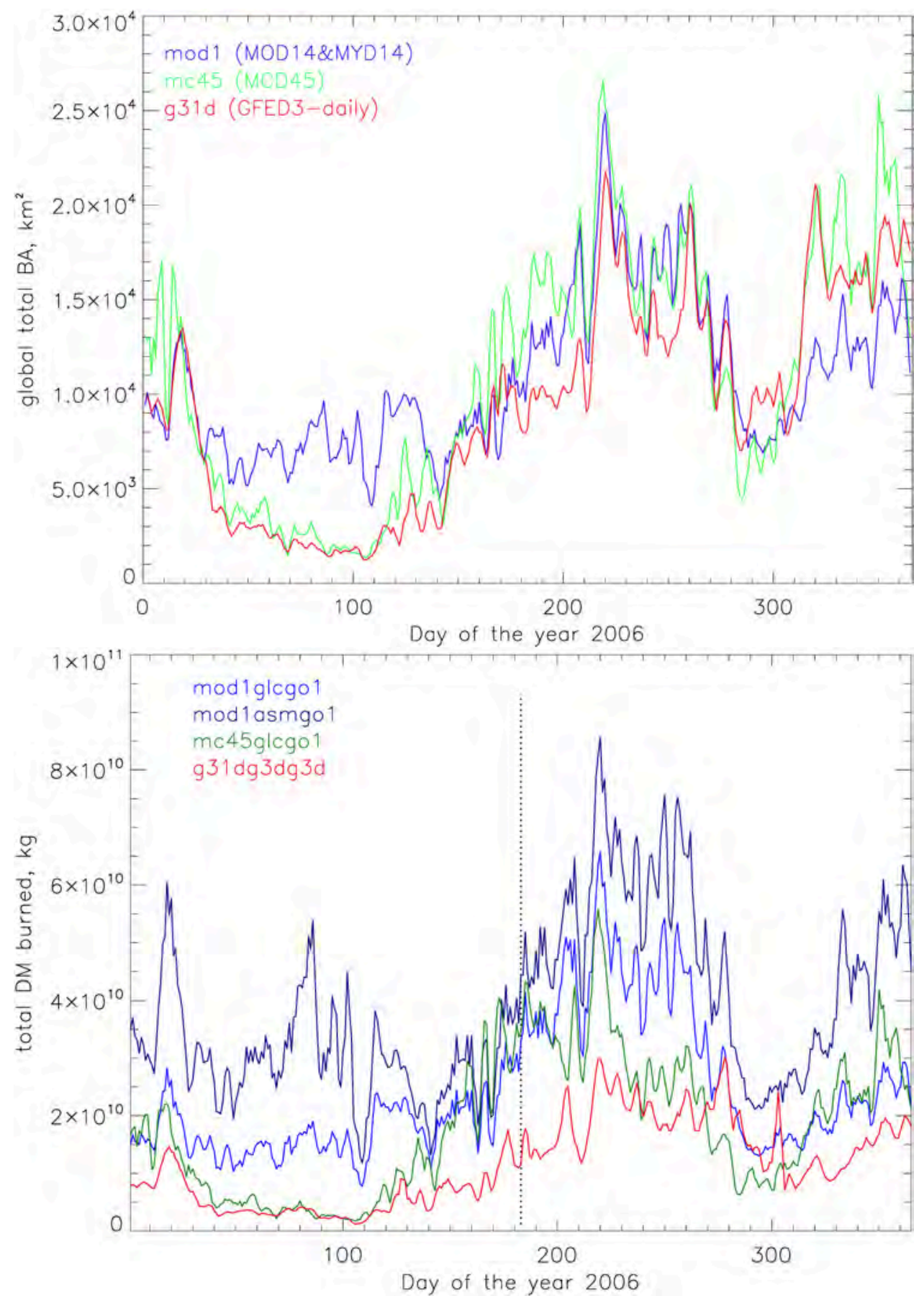

Figure 3. Top: Global daily total burned area in 2006 from three different products: $\bmod 1=$ MODIS fire count based estimate using combined Terra (MOD14) and Aqua (MYD14) fire counts; mc45 = burned area product (MCD45, Roy et al., 2008); and g31d (GFED version 3 daily product). Bottom: Global daily total burned dry mass in 2006 from different combination of burned area as shown in the top panel, the available biomass (glc $=$ Global Land Change dataset, asm $=$ A. Soja (2004) medium fire intensity, and g3d $=$ GFED v3 daily) (from Petrenko et al., 2011). 

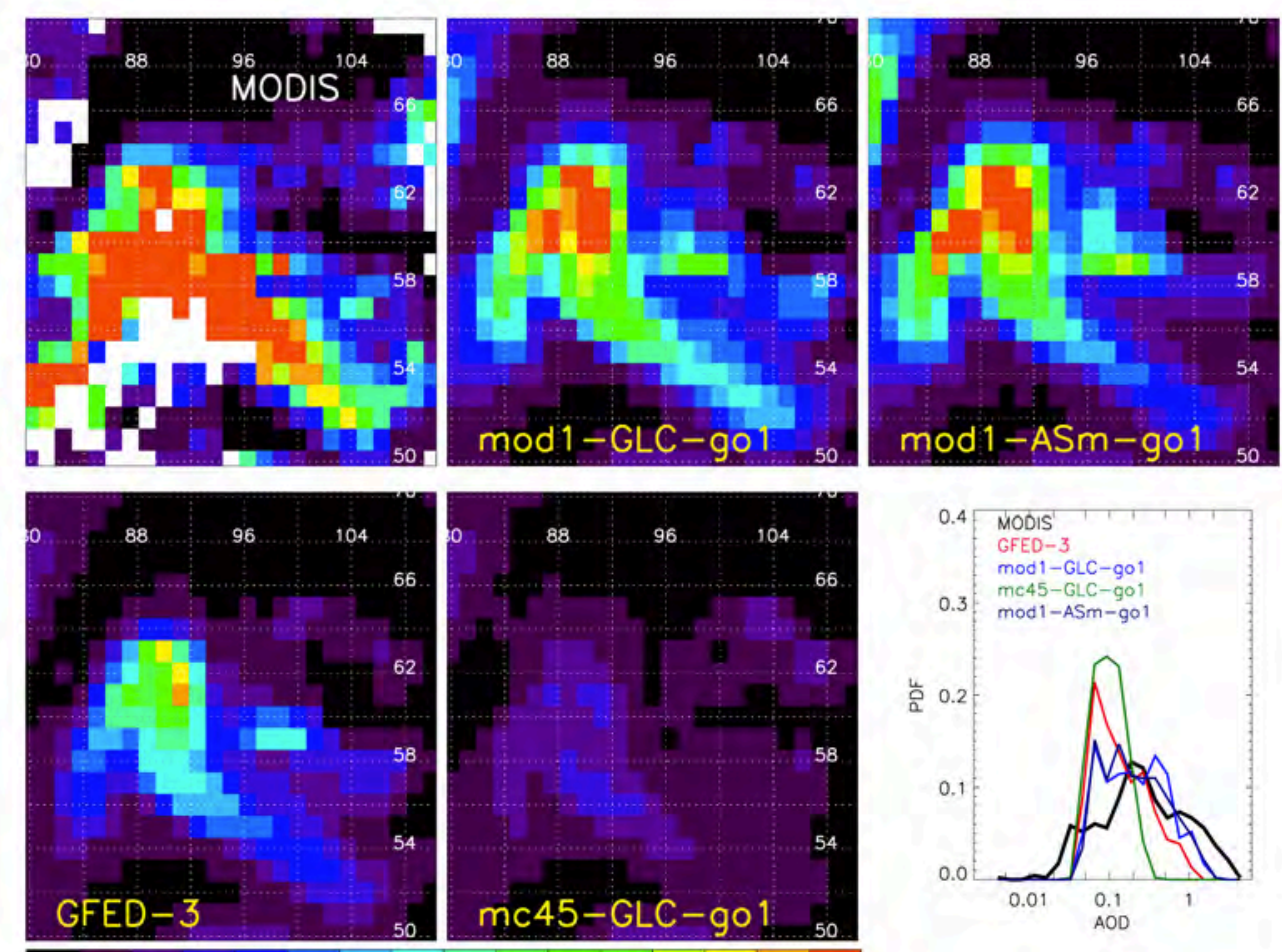

Figure 4. Comparisons of biomass burning AOD from MODIS retrievals and GOCART simulations using different dry mass burned (see bottom panel in Figure 3 ) and emission factors (gol = emission factors of BC, OC and SO2 used in current GOCART model, see Chin et al., 2004; GFED-3 = emission factors from Andrea and Merlet 2001 used in GFED v3) over the north of Lake Baikal in Russia in 2006-07-20. The last panel shows the probability distribution function of AOD distributions in the regions (from Petrenko et al., 2011). 


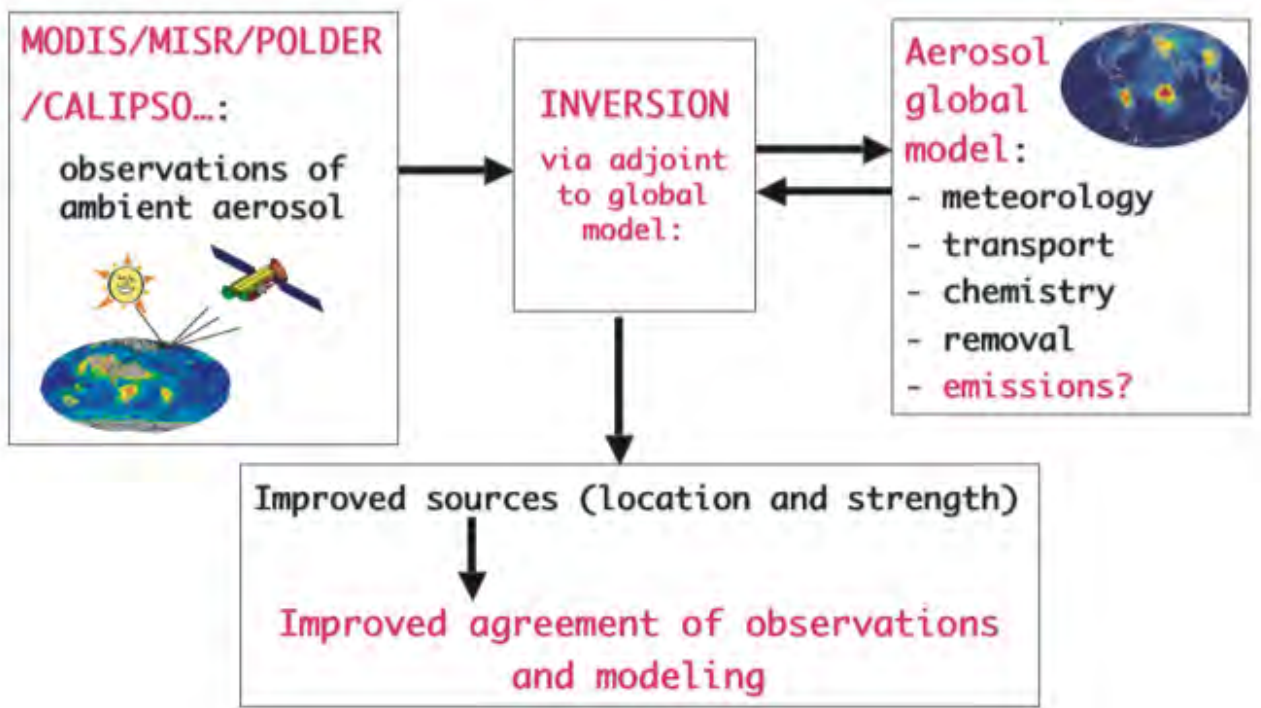

Figure 5. Schematic of an inverse modeling processes (from Dubovik et al., 2008). 